\title{
REVIEW OF INTERNATIONAL EXPERIENCE WITH RENEWABLE ENERGY OBLIGATION SUPPORT MECHANISMS
}

\author{
N.H. van der Linden, ECN \\ M.A. Uyterlinde, ECN \\ C. Vrolijk, IT Power \\ L.J. Nilsson, University of Lund \\ J. Khan, University of Lund \\ $\mathrm{K}$. Åstrand, University of Lund \\ K. Ericsson, University of Lund \\ R. Wiser, Lawrence Berkeley National Laboratory
}




\section{Acknowledgement/Preface}

This study, commissioned by the Dutch Ministry of Economic Affairs, was conducted jointly by the Energy research Centre of the Netherlands (ECN), IT Power, UK, Lawrence Berkeley National Laboratory, USA, and University of Lund, Sweden. The responsibilities for the preparation of this report were as follows:

- ECN prepared Chapters 1 and 2 and contributed to Chapter 3 and 7. ECN was also responsible for the final editing of the report.

- IT Power, UK prepared Chapter 4 and contributed to Chapter 7.

- Lawrence Berkeley National Laboratory, USA, prepared Chapter 6 and contributed to Chapter 3 and 7; detailed review of the entire report.

- University of Lund, Environmental and Energy Systems Studies at the Department of Technology and Society, Sweden, prepared Chapter 5 and contributed to Chapter 7.

The study is registered under ECN project number 7.7597. The final report can be downloaded from the ECN website www.ecn.nl.

The project team highly appreciates the valuable comments and contributions received during the execution of the study from the Dutch Ministry of Economic Affairs, the Swedish Ministry of Sustainable Development and from Jaap Jansen (ECN) who reviewed the final draft report. Naturally, the sole responsibility of this report lies with the authors.
Abstract
- Effectiveness
- Market efficiency
- Certainty for the renewable energy industry
- Cost effectiveness
- Stakeholder support for the obligation system, and
- Equity.

The main policy instruments currently used in the EU Member States to achieve the targets set for electricity produced from renewable energy sources are: 1) the quota obligation system; 2) the feed-in tariff system; and 3) the tendering system. The current study aims to review the experience gained with the quota obligation system. The report provides an overview of the regions where obligation systems have been implemented and contains a detailed evaluation of the performance of the obligation systems in the USA, the UK and in Sweden. The obligation systems in these countries have been evaluated based on the following criteria:

The evaluation of international experiences with the obligation system gives rise to a mixed picture. Although an obligation in theory is effective and cost effective, it seems too early to conclude that the system delivers these promises in practice. On the one hand this is due to the limited period of implementation that makes it hard to distinguish between the direct effect of the system and some teething problems that will be solved in due time. On the other hand, the conclusion can be drawn that the obligation is a complex system, which will only function well if designed carefully. It does seem worthwhile, however, to continue monitoring the experiences with the obligation system abroad, because this will further reveal whether the system is indeed effective and cost effective in practice. In the longer term, e.g. beyond 2010, the introduction of an obligation system in the Netherlands could be considered. Finally, as the design of support schemes is being improved, it appears that the basic concepts of both the obligation system and the feed in system have been refined in such a way that the two systems are gradually converging. An important difference between the two systems however remains, namely that an obligation system relies more on market forces whereas the feed-in system is based on a greater involvement of the government. 


\section{CONTENTS}

List of tables $\quad 5$

List of figures $\quad 5$

Summary 6

1 Background 9

2 Overview of renewable energy policy support instruments 10

$\begin{array}{ll}2.1 & \text { Main policy support instruments } \\ & 10\end{array}$

2.1.1 The quota obligation scheme $\quad 10$

2.1.2 The feed-in tariff scheme 11

2.1.3 The tendering scheme 11

2.2 Other accompanying measures 12

2.3 Cost effectiveness of obligation system compared to feed-in tariff 12

$3 \quad$ Current applications of obligation schemes 16

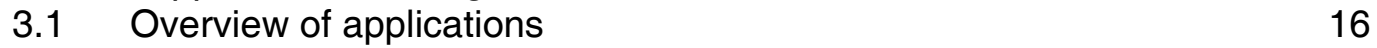

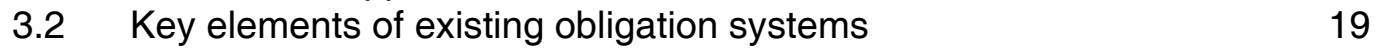

3.3 Criteria for evaluating the performance of obligation schemes 23

$4 \quad$ Experience in the UK 24

4.1 Introduction 24

4.2 Evaluation of the performance of the obligation scheme 26

$\begin{array}{ll}4.2 .1 \text { Effectiveness } & 26\end{array}$

4.2.2 Market efficiency 28

4.2.3 Certainty for the renewable energy industry 29

4.2.4 Cost effectiveness 30

4.2.5 Stakeholder support for the system 30

$\begin{array}{ll}\text { 4.2.6 Equity } 31 & 31\end{array}$

4.2.7 Other key issues 31

4.3 Conclusions and lessons learnt 32

$5 \quad$ Experience in Sweden 34

$\begin{array}{lll}5.1 & \text { Introduction } & 34\end{array}$

5.2 Evaluation of the performance of the obligation scheme 34

5.2.1 Effectiveness 35

5.2.2 Market efficiency 36

5.2.3 Certainty for the renewable energy industry 37

5.2.4 Cost effectiveness 38

5.2.5 Stakeholder support for the system 39

$\begin{array}{ll}5.2 .6 \text { Equity } & 40\end{array}$

5.3 Other key issues 41

5.4 Conclusions and lessons learnt 43

$6 \quad$ Experience in the U.S.A 45

6.1 Introduction 45

6.2 Evaluation of the performance of the obligation scheme 45

6.2.1 Effectiveness 45

6.2.2 Market efficiency 47

6.2.3 Certainty for the renewable energy industry 48

6.2.4 Cost effectiveness 49

6.2.5 Stakeholder support for the system 50

$\begin{array}{lll}6.3 \text { Equity } & 50\end{array}$

6.4 Conclusions and lessons learnt 51 
7.1 Main results and conclusions for each criterion 53

7.1.1 Effectiveness 53

7.1.2 Market efficiency 54

7.1.3 Certainty for the renewable energy industry 55

7.1.4 Cost effectiveness 56

$\begin{array}{ll}7.1 .5 & \text { Stakeholder support for the obligation system } \\ 7.1 .6 & 57\end{array}$

$\begin{array}{ll}7.1 .6 \text { Equity } & 58\end{array}$

7.2 Recommendations on the design of a quota obligation 59

7.3 Feasibility of introducing a quota obligation system in the Netherlands 60

$\begin{array}{ll}7.4 & \text { Finally: convergence of different support schemes? }\end{array}$

References $\quad 62$

Summary in Dutch $\quad 64$

S.1 Wat is een verplichtingssysteem? 64

S.2 Ervaringen met verplichtingssystemen $\quad 65$

$\begin{array}{ll}\text { S.3 Conclusies van de evaluatie } & 66\end{array}$

S.3.1 Effectiviteit: zorgt het systeem voor een groei in de elektriciteit opgewekt met hernieuwbare bronnen? 66

S.3.2 Werkt de groencertificatenmarkt efficiënt? 66

S.3.3 Biedt een verplicht aandeel voldoende zekerheid voor producenten?

67

S.3.4 Is een verplicht aandeel kosten effectief? $\quad 67$

S.3.5. Steun van marktpartijen voor het verplichtingssysteem 69

$\begin{array}{ll}\text { S.3.6 Eerlijke verdeling van kosten en baten over de } & \\ \text { belangengroepen } & 69\end{array}$

S.4 Hoe ziet een goed ontworpen verplichtingssysteem eruit? 69

S.5 Is een verplichtingssysteem geschikt voor Nederland? 70

S.6 Tenslotte: systemen kunnen convergeren 71 


\section{List of tables}

Table 3.1 Key design elements for a Select group of state RPS policies

Table 3.2 Key design elements of existing obligation systems in Europe and Japan 22

Table 4.1 Detailed description of resources eligible for the UK obligation system 26

Table 5.1 Number of plants approved for TRECs as of 1 May 2004

Table 7.1 TREC prices per MWh in $€$ for several countries/regions

\section{List of figures}

Figure 2.1 Flow chart of the main components of a TREC system 10

Figure 2.2 Example of a RES-E supply curve 13

Figure 2.3 Example of the supply curve in a feed-in premium system 14

Figure 2.4 Example of the supply curve in an obligation system 15

Figure 3.1 Existing state RPS policies in the US 16

Figure 3.2 The date of adoption of, or major revision to, state RPS policies $\quad 17$

Figure 3.3 Overview of renewables support schemes in the EU-25 18

Figure 4.1 Renewable electricity generated in the UK on a ROC-eligible basis 27

Figure 4.2 Comparison of the percentage of each supplier's RO that was satisfied by ROCs or SROCs in 2002/3

Figure 6.1 The projected impact of state RPS policies by 2017

Figure 6.2 Recent prices for vintage 2004 TRECs among states

Figuur S.1 Voorbeeld van een aanbodcurve in een verplichtingssysteem (links) en een systeem van terugleververgoedingen (rechts). De grijze arcering geeft een indicatie van de totale uitgaven. 


\section{Summary}

The main policy instruments currently used in the EU Member States to achieve the targets set for electricity produced from renewable energy sources are: 1) the quota obligation system; 2) the feed-in tariff system; and 3) the tendering system. The current study, commissioned by Dutch Ministry of Economic Affairs, aims to review the experience gained with the quota obligation system, and thus to provide background information to enable the Dutch Government to better determine its own position in national and European discussions on renewable electricity support schemes.

The report provides an overview of the regions where obligation systems have been implemented and contains a detailed evaluation of the performance of the obligation systems in the USA, the UK and in Sweden. The obligation systems in these countries have been evaluated based on the following criteria:

- Effectiveness: Defined in terms of achieving a large amount of RES-E capacity added or production generated, this indicator relates to the quantitative impact of the obligation system in promoting new renewable energy.

- Market efficiency: Obligation systems are often argued to result in cost competition and therefore a minimization of costs in supporting renewable energy. In principle, well defined obligation markets should lead to such competition and therefore an efficient allocation of resources in support of renewable energy. Do obligation/TREC markets function well in practice, minimizing the cost of supporting renewable energy?

- Certainty for RES-E industry: Growth of RES-E capacity ultimately depends on the decisions of individual investors. This criterion assesses whether or not the system is perceived as stable in the short and long term from the perspective of investors.

- Cost effectiveness: This measure is defined as the costs per kWh of RES-E, including the 'dead weight' costs such as transaction costs, overcompensation of certain market actors etc.

- Stakeholder support for the system: The success of the obligation system may depend, in part, on the level of support the system has from various stakeholders. Widespread stakeholder support may also indicate a well-functioning policy.

- Equity: From a government point of view and for long-term sustainability of the system, a fair distribution of costs and benefits of RES-E implementation over various stakeholders is important.

This summary presents the overall conclusions for each criterion.

\section{Effectiveness}

Definite conclusions on the effectiveness of quota obligation systems in terms of reaching the set RES E targets cannot yet be drawn. Where targets have not been achieved, it has been primarily due to poor policy design and a lack of certainty for renewable energy producers; permitting barriers have also arisen. In addition, there are some instances of strategic behaviour of obligated actors leading to unwanted side effects. These teething problems may well be solved over time when the actors become more familiar with the system and market forces bring about a more stable equilibrium. In addition, several revisions are being proposed to address the problem of long-term security and to create a conducive environment for negotiating long term TREC sales contracts, which will also reduce the incentive for strategic behaviour. Experience in the US shows that if certificates are delivered under long-term agreements, the effectiveness of an obligation can be high and compliance levels can be reached. Whether and under what circumstances such long-term contracts are available will be a key determinant of success for obligation policies. 


\section{Market efficiency}

In Europe, market efficiency generally is rather poor because of the limited number of participating actors and/or producers, and because of the limited degree of long term contracting. It is expected that, over time, as the market size increases and as the systems are revised to facilitate long term contracting, market efficiency will improve leading to lower long and short-term TREC prices. In the US, where the obligation system was introduced earlier and negotiating long-term contracts is more common, market efficiency is generally satisfactory in a number of states. In other states, however, short term TREC trade dominates, and that trade is sometimes at high prices that are more driven by penalty levels than by supply and demand. To some extent, this is a remarkable observation, contrary to what intuitively is perceived by many as efficient. If TRECs are delivered under long-term agreements, the TRECs are effectively withdrawn from the market and the price may not be known publicly. This hampers liquidity and transparency of the short term TREC market, but to the extent that renewable energy developers are able to deliver lower cost renewable generation with the certainty of a long-term contract, such contracting will lower the cost of compliance with the obligation and thereby increase efficiency.

\section{Certainty for the renewable energy industry}

A sufficient level of certainty for the renewable energy industry is imperative for a well functioning obligation system. A precondition is to set long term RES E targets: 10 years ahead appears to be the minimum horizon, which is already a long period from a political point of view. Uncertainty due to short term TREC price fluctuations is notably a problem in the UK due to the recycle payment. Revisions of the obligation system as a result of a review can also easily lead to greater uncertainty among RES E producers. This may limit the government's flexibility to adjust the system in the course of time.

\section{Cost effectiveness}

Obligation systems can encourage cost reduction and competition, but its design is more complex than a feed-in tariff. An obligation system will generally stimulate the lowest cost and least risky renewable technologies, thereby allowing a set target to be met in an efficient way. Moreover, the total costs of an obligation system can be capped by the size of the quota and the level of the penalty. Short-term TREC markets can lead to overcompensation of existing capacity or low-cost production, but this can be countered in several ways. First, by technology-specific (investment) subsidies, creating a more level playing field in the TREC market, or by developing technology or vintage tiers under the obligation system. Furthermore, the cost effectiveness of an obligation system can be improved by (1) using penalty revenues to stimulate renewables, instead of flowing to the state; and/or (2) encouraging a high level of compliance by setting a relatively high penalty. The system employed in various US states, where obliged suppliers offer long-term contracts to producers in competitive tenders, seems to have the benefit of combining effectiveness and cost efficiency. Without the use of some of the mechanisms described above, and absent careful design, international experience shows that obligation systems will not lead to cost-effective outcomes.

\section{Stakeholder support for the obligation system}

Generally speaking, there is sufficient support for the obligation system from the key renewable energy stakeholders, both in Europe and in the US. The obligation system is often perceived to provide more long term security, at least relative to earlier support policies in the countries in which obligation systems have been introduced, because obligation systems may be less prone to changing political circumstances, compared to other RES-E support instruments. Most criticism therefore is not so much directed against the system itself, but more against specific design elements of the system. Those that have initially opposed obligation systems have generally been the obliged suppliers and industrial customers. In addition, in those countries with wellfunctioning feed-in tariff systems, obligation systems are often opposed by renewable energy industry lobbies, which have grown accustomed to the existing support system and do not want to risk a new and uncertain policy. 


\section{Equity}

Equity aspects should be duly taken into account when designing a quota obligation system to ensure sufficient long-term support from the main stakeholders. Obligation systems seem to be less suited for small RES-E producers. Other important aspects are the exemptions of particular groups from the system, and the creation of a level playing field for RES-E technologies.

\section{Final remarks}

The evaluation of international experiences with the obligation system gives rise to a mixed picture. Although an obligation in theory is effective and cost effective, it seems too early to conclude that the system delivers these promises in practice. On the one hand this is due to the limited period of implementation that makes it hard to distinguish between the direct effect of the system and some teething problems that will be solved in due time. On the other hand, the conclusion can be drawn that the obligation is a complex system, which will only function well if designed carefully. It does seem worthwhile, however, to continue monitoring the experiences with the obligation system abroad, because this will further reveal whether the system is indeed effective and cost effective in practice. In the longer term, e.g. beyond 2010, the introduction of an obligation system in the Netherlands could be considered. Finally, as the design of support schemes is being improved, it appears that the basic concepts of both the obligation system and the feed in system have been refined in such a way that the two systems are gradually converging. An important difference between the two systems however remains, namely that an obligation system relies more on market forces whereas the feed-in system is based on a greater involvement of the government. 


\section{Background}

The Directive on the Promotion of Electricity Produced from Renewable Energy Sources in the Internal Electricity Market ${ }^{1}$ is the main legislation affecting renewable electricity at the EU level. This Directive aims at facilitating a significant increase in renewable electricity from $13 \%$ in $1999 / 2000$ to $21 \%$ in 2010 for EU-25 as a whole. The Directive also establishes indicative targets for the penetration of renewable electricity for each Member State.

Three main policy instruments are currently used by the Member States for promoting electricity production from renewable energy sources and achieving the indicative targets: 1) the quota obligation system, also referred to as renewables portfolio standards (RPS) or renewable energy targets; 2) the feed-in tariff system; and 3) the tendering system. In addition, a variety of accompanying measures are being applied in the Member States for achieving the objectives of particular renewable energy technologies. In the Directive it is stated that the Commission intends to produce a report in 2005 on the experience gained with the application and coexistence of these different policy instruments.

The indicative target set for the Netherlands is $9 \%$ by the year 2010, up from $3.2 \%$ in 2000 . The $\mathrm{MEP}^{2}$ feed in premium system - which provides a fixed payment for eligible renewable resources - has been chosen as the most appropriate instrument in the Netherlands to achieve this target. Although the Dutch Government has no intention to reconsider this decision, there is a need for more background information on the experience gained with other support mechanisms for electricity produced from renewable energy sources (RES-E). This would facilitate an evaluation of the merits and disadvantages of the various RE support mechanisms and would enable the Dutch Government to better determine its own position in the discussions initiated by the Commission on community-wide renewable electricity support schemes.

Renewable energy obligation systems have recently been implemented in Australia, the USA, Europe, and Japan. Many, but not all, of these policies are backed by a Tradable Renewable Energy Certificate (TREC) system. A TREC system may ease the process of compliance verification and may also increase compliance flexibility, thereby reducing the cost of the quota obligation. Though experience with obligation systems is somewhat limited, the present study aims to review the early experience gained in some of the regions that have developed such policies.

The outline of the report is as follows: Chapter 2 presents a brief description of the obligation and linked TREC system and explains the main differences between this policy approach and other renewable energy support mechanisms commonly used in Europe. Chapter 3 gives a brief overview of the regions worldwide where obligation systems have been implemented, describes some of the key design elements of an obligation system and explains the criteria used in this study for measuring the performance of existing obligation systems. Chapters 4, 5 and 6 provide detailed assessments of the experience with obligation systems in the UK, Sweden and the USA. Finally, in Chapter 7, the conclusions and recommendations of this report are presented.

\footnotetext{
Directive 2001/77/EC.

The MEP payment is intended to reflect the environmental quality of electricity production and is paid to producers of renewable electricity who feed in on the national grid; it is guaranteed for a maximum of ten years.
} 


\section{Overview of renewable energy policy support instruments}

\subsection{Main policy support instruments}

\subsubsection{The quota obligation scheme}

The use of quota obligation systems to support renewable energy, while relatively new, is becoming increasingly common. An obligation system - also referred to as a renewables portfolio standard (RPS) or renewable energy target - aims to support new renewable energy generation by increasing demand for renewable electricity. It does this by establishing the amount or proportion of electricity supply that must be produced from eligible renewable energy sources. The obligation is typically imposed on consumption, often through supply or distribution companies, but is, in at least one case (Italy), being applied to electricity producers. The implementation of an obligation system usually involves a penalty for non-compliance to ensure that obligated parties meet their renewable energy purchase obligations. As shown later, the actual design of obligation systems can vary considerably among regions.

To simplify the burden of verifying compliance, and to provide flexibility in achieving compliance, obligation systems often use 'Tradable Renewable Energy Certificates' (TREC). The TREC represents the 'renewable' value of electricity produced from renewable sources and allows sale of that benefit to be detached from the sale of the physical electricity. TRECs can be traded, banked and consumed like any other commodity. TRECs can and often are sold still bundled with the underlying physical electricity production, but selling TRECs separately from the underlying electricity can provide useful compliance flexibility. Smaller suppliers, or suppliers in transmission constrained areas, for example, may not be equipped to handle the delivery of intermittent wind generation, in which case the purchase of TRECs (and not the underlying electricity) may be the least cost compliance option. TREC systems can also simplify the regulators role in verifying compliance with the obligation system. Figure 2.1 presents a schematic representation of a typical obligation policy that uses TRECs for compliance verification.

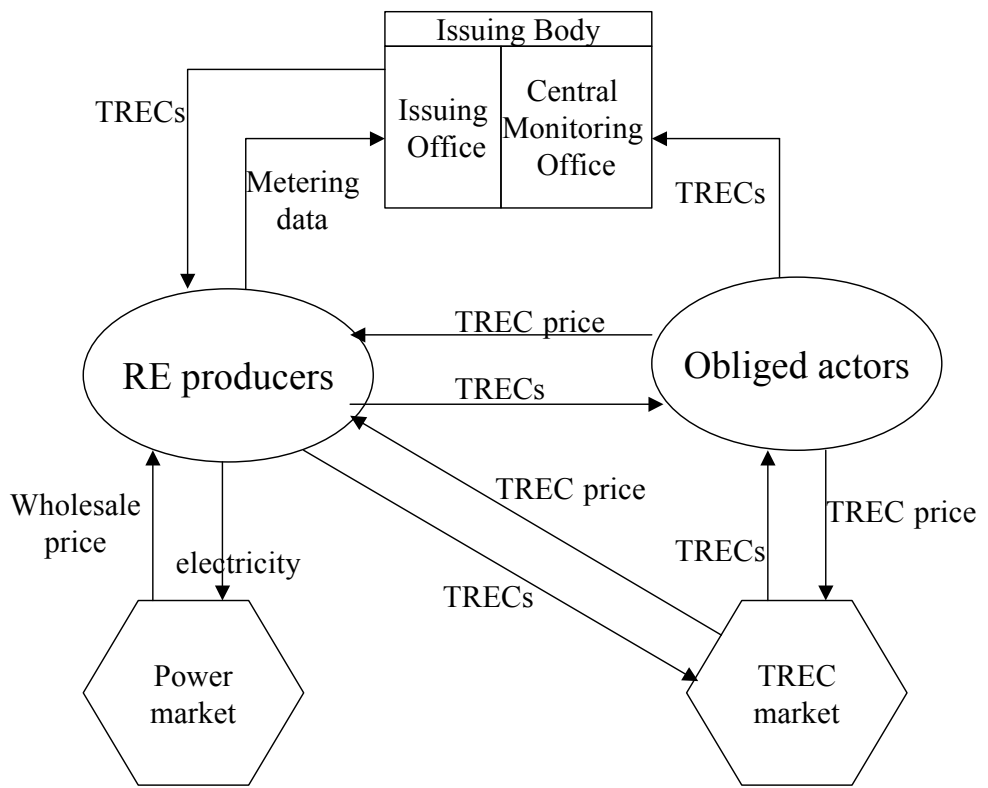

Figure 2.1 Flow chart of the main components of a TREC system

Under an obligation system, an increasing demand for renewably electricity from obligated actors (usually retail electricity suppliers) drives demand for TRECs. These obligated actors will 
purchase TRECs either directly from the RES-E producers or from the brokers or other intermediaries. To verify compliance with the obligation, obligated actors must retire or hand over the requisite number of TRECs, typically on an annual basis, to the monitoring authority. The TRECs will therefore attain a monetary value and provide an incentive for producers to produce them. In this way, the revenues for RES-E producers will be the sum of the price for physical electricity sold to the power market and the price for TRECs.

It deserves note that TRECs are usually not actual paper certificates, but are instead electronic records (much like a bank account) handled by means of administrative software, which issues, tracks, and registers certificates. This software typically includes a central registration database of accounts on which certificates can be deposited and withdrawn.

\subsubsection{The feed-in tariff scheme}

Feed-in tariff systems have historically been the driving force behind renewable energy development in the EU, as witnessed by the success of the current German and Spanish systems, and the previous success of the Danish policy (as well as even earlier experience in the state of California). In the feed-in system all qualifying electricity generated from renewable energy sources is paid a premium price for delivery to the grid. In this system the government sets the price of electricity produced from renewable sources, which can depend on many factors. The utilities are obliged to purchase this electricity at the set price. As generation costs differ across renewable energy technologies, the feed-in tariff is usually different by technology and is provided for a specified period of time. The price may also decline over time, tracking expected renewable energy cost reductions.

In theory, by setting the price but not (directly) the quantity produced, it is not entirely certain a priori how much renewable electricity will be promoted. That said, the stability that is provided by establishing a set price, if that price is high enough, can lead to sustained and sizable growth in renewable energy generation. Such growth has recently been experienced in both Germany and Spain. The main criticism of feed-in tariff systems is that - if the price is set too high - the system may result in excess profits to producers that come at the expense of electricity consumers.

\subsubsection{The tendering scheme}

A tendering system typically involves a government-administered competitive bidding process through which renewable energy developers vie for access to power purchase agreements and/or access to a government-administered fund. There are sometimes separate tenders for different RE technologies. Within each technology band, contracts (and the corresponding support) are awarded to the most competitive bids. Electric utilities are often obliged to purchase the electricity at the price proposed by the winning bids (sometimes supported by a government fund). Such tendering systems have been used in the UK, Ireland, France, the US, and China, to name a few countries.

These procedures, which stimulate strong competition between renewable electricity generators and hence result in cost-efficiency and price reduction, have not yet been greatly successful in promoting renewable electricity, at least relative to feed-in systems. This may be due to the intermittency of the tenders, and the resulting uncertainty in the market, or may be due to the complexity of the procedures involved. Some have also argued that such solicitations can lead to unrealistically low renewable energy bids, and thereby result in committing funds to projects that do not materialize. 


\subsection{Other accompanying measures}

In addition to the main policy instruments for stimulating renewable energy discussed above, the following accompanying measures are sometimes used to achieve the objectives set for specific renewable energy technologies.

1. Financial subsidies: Renewable energy power plants are often capital intensive with relatively low running costs. Therefore, governments may offer financial subsidies for renewable electricity technologies in terms of specific $\$ / \mathrm{kW}$ grants, or grants set as a percentage on total investment. Investment subsidies are the oldest, and still a very common type of support. This may be explained by the fact that such systems are often politically feasible and easy to administer. However, a major disadvantage of this instrument is the lack of incentive to operate the plant as efficiently as might be the case if production-based financial support were offered (Schaeffer et al, 2000; Faber et al, 2001) ${ }^{3}$. As a result of these concerns, a growing number of countries have begun to apply financial incentives on a production basis.

2. Tax incentives: A wide array of tax incentives can be grouped in this category including: exemption of renewable electricity from energy taxes, tax refunds for renewable electricity, lower VAT rates for renewable electricity, and exemption of investments in renewable electricity plants from income or corporate taxes. They all increase the competitiveness of renewable electricity, and may be based on investment or on production. Such tax incentives are widespread, probably because they are usually easy to implement and because the cost of such efforts is often opaque and buried in government budgets.

3. Green marketing: In these systems a premium on the electricity bill is paid voluntarily by consumers to promote renewable electricity. This premium is then paid, at least to some degree, to the RE generators to cover the additional generation costs of renewable electricity. Obviously, this system depends on the consumer's willingness to pay (WTP) for renewable electricity which differs from country to country. Such WTP is influenced by factors related to consumer environmental awareness and specific market conditions (e.g. degree of market opening) (Faber et al 2001). For the investor, it should be noted that green marketing has not yet generally produced a large and sustained demand for renewable energy, unless that demand is heavily subsidised. This may partly be due to consumer scepticism about the premium being used effectively to promote renewables.

In addition to these policy measures, the introduction of RES-E technologies also depends on the conditions under which RES-E producers get access to the grid, as well as various permit procedures. For example, wind power may be penalized for being intermittent and for being located far from load centres. Complicated permitting procedures will increase transaction costs and discourage investments. Hence, fair and transparent regulations concerning aspects such as grid access and building permits is also important for promoting RES-E technologies.

\subsection{Cost effectiveness of obligation system compared to feed-in tariff}

There is a large body of literature discussing the pros and cons of obligation systems and feed-in tariffs, (see for instance: Sawin, 2004; Menanteau et al, 2003; Lauber, 2004; Jansen and Uyterlinde, 2004). The current report does not aim to join this debate in comparing these schemes, but rather adds a new element to the discussion by reviewing early experience with obligation systems. However, to provide a basis for conclusions on cost effectiveness of obligation systems at

\footnotetext{
A scheme of gradually decreasing investment subsidies might be given to potential investors in order to discourage delays in investments due to expected price decreases of the technology. Subsidy programmes may also lead to further delays in investments, as they usually require the applicant to wait for the approval of the subsidy before beginning to install the plant. Finally, and apart from the problem of 'windfall gains', an investment subsidy does not prevent the subsidised generator from stopping production in the near future.
} 
a later stage, this section will summarise some theoretical considerations regarding the cost effectiveness of the two support schemes.

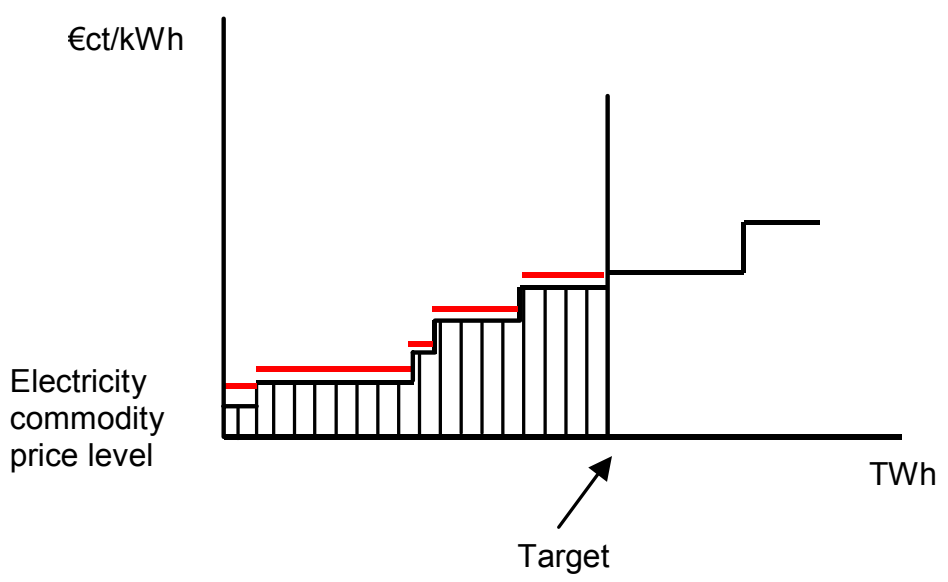

Figure 2.2 Example of a RES-E supply curve

Note: the striped area indicates the additional production costs reflecting the investment deficit that any support scheme intends to compensate.

Under perfect information, the least cost way to achieve a given RES-E target is to provide financial support to the cheapest technologies, up to the production level required for achieving the target. Support would ideally be slightly above the production costs to offer producers a reasonable return on investment.

In Figure 2.2, this is indicated by the support levels just above the striped area. Both the obligation system and feed-in tariffs try to approximate this situation, but they do so in opposite ways.

A feed-in system is a price driven instrument and often aims to set the support level close to the level of production costs. By creating stability in the market, a feed-in tariff system may reduce financing barriers and costs. However, in practice, there is a lack of information on both the level of the production costs, and on the required mix of technologies. Therefore, feed-in tariff systems will only be able to approximate the ideal situation, and will either pay too much and overshoot the target (illustrated in Figure 2.3), or not achieve the target at all. Moreover, the information on production costs, which is crucial for setting the feed-in tariffs, comes to a large extent from the generators, who have little incentive to accurately report those costs. Consequently it may be difficult to set the support level appropriately, which may lead to windfall profits for some producers. 


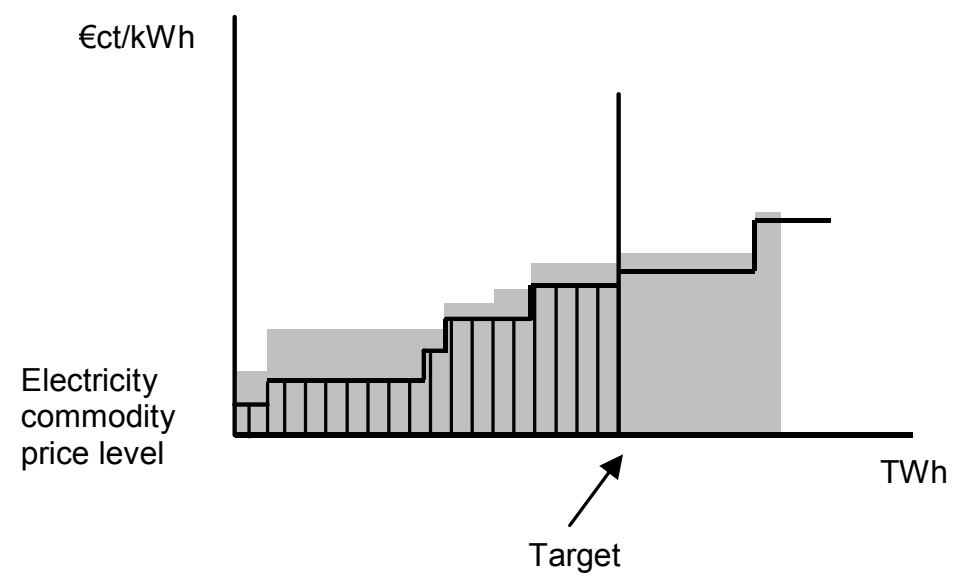

Figure 2.3 Example of the supply curve in a feed-in premium system Note: grey area represents total support expenditures.

On the other hand, an obligation system is a quantity driven instrument. Provided that penalties are enforced well and the quota does not exceed readily available supply in the long term, an obligation is likely to ensure that targets are met ${ }^{4}$; however, the cost of the system cannot be known in advance with certainty. An obligation system can be cost effective because its design warrants that the least expensive technologies are used for meeting the RES-E target. Furthermore, competition is supposed to provide a strong incentive to RES-E producers to reduce costs, thereby improving cost effectiveness in the long run. However, one uncertain factor here is the level of the equilibrium price, given by the price of the marginal option. A system with a high TREC price (due to an ambitious quota, a high penalty, or other conditions) may provide excess profits for existing and new capacity ${ }^{5}$. This is illustrated in Figure 2.4, where the grey area represents the total expenditures while the striped area represents the additional production costs. Clearly there may be a group of low cost existing (or new) producers that is overcompensated. A second concern relates uncertainty in the underlying political commitment behind the obligation, which can lead to short term trade in TRECs and little long-term contracting. Such an uncertain environment can lead to higher financing costs, reducing the presumed benefits of the system from a cost-effectiveness standpoint.

Finally, it should be pointed out that in a generic obligation system, the short-term emphasis on low cost compliance can neglect the investment required to take more expensive technologies down the learning curve.

4 If the obligation exceeds a reasonably achievable level, the existence of other barriers will prevent the market players to meet their obligation level.

5 Note that this is not specific to a TREC market; in all liberalised markets price setting is based on marginal costs instead of average costs, and low-cost producers will be able to gain good profits. 


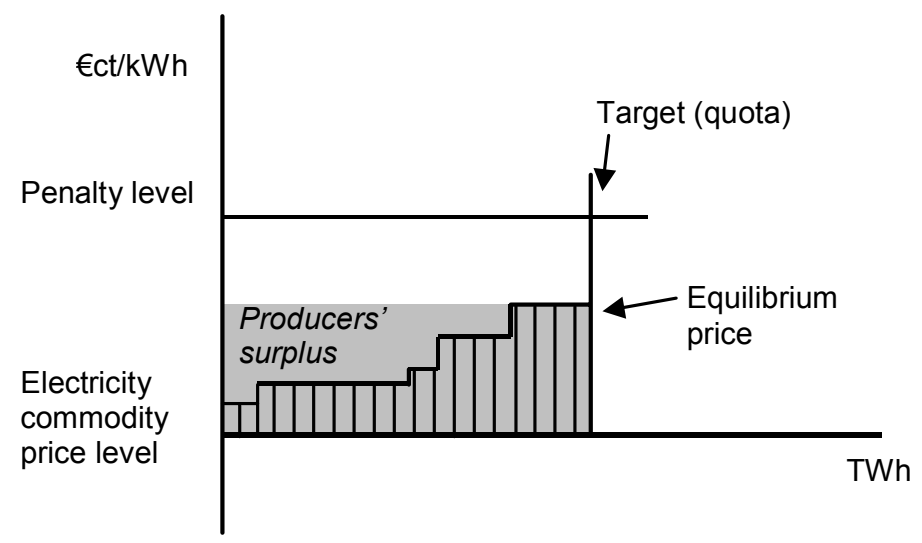

Figure 2.4 Example of the supply curve in an obligation system Note: grey area represents total support expenditures.

We conclude that both types of support schemes have their strengths and weaknesses, which depend to some extent on design and implementation. Ultimately, the choice between these systems is a political one, and each system can be made to function well or can be designed ineffectively. Each system can also be designed to help overcome its perceived weaknesses. For instance, feed-in tariffs can decline over time and thus introduce an incentive for cost reduction. In the same way, the design of obligation systems can be further refined to include technology tiers in order to create submarkets with more homogenous supply curves and therefore reduce excess profits (Verbruggen, 2004). ${ }^{6}$

6 However, some markets may be too small to provide for sufficient liquidity if technology or vintage tiers were implemented. Other solutions are to strictly limit eligibility to new capacity, although this may lead to 'repowering' strategies, or to give investment support to the more expensive technologies, thus reducing additional costs of these producers (flattening the supply curve). 


\section{Current applications of obligation schemes}

\subsection{Overview of applications}

Though there was some previous experience with obligation systems, the concept emerged in a significant way the late 1990s in the US (where obligation systems are called a Renewables Portfolio Standards, or RPS), Australia (called the Mandatory Renewable Energy target), Japan, and several European countries. This chapter presents a brief overview of the current applications worldwide and summarises some of the key design elements of the obligation systems implemented in selected countries. Finally, a set of criteria is presented and discussed that is used in Chapters 4-6 to evaluate the performance of the obligation systems implemented in the US, Sweden and the UK.

\section{United States}

The first applications of quota obligation systems appear to have occurred in the United States, at the state (rather than federal) level. Though the federal government plays an important role, states have historically been the innovators in supporting the commercial application of renewable energy technologies in the US. Renewables portfolio standards (RPS), and related mandates, have recently become the most popular form of that encouragement.

Texas has perhaps the most well-known RPS in the United States (Langniss and Wiser 2003), but as of March 200518 states and Washington, DC had developed renewable energy portfolio standards or mandates. These policies cover approximately $40 \%$ of total US customer load. ${ }^{7}$ Figure 3.1 identifies the states in which RPS policies have been established, as well as their terminal renewable energy purchase requirements.

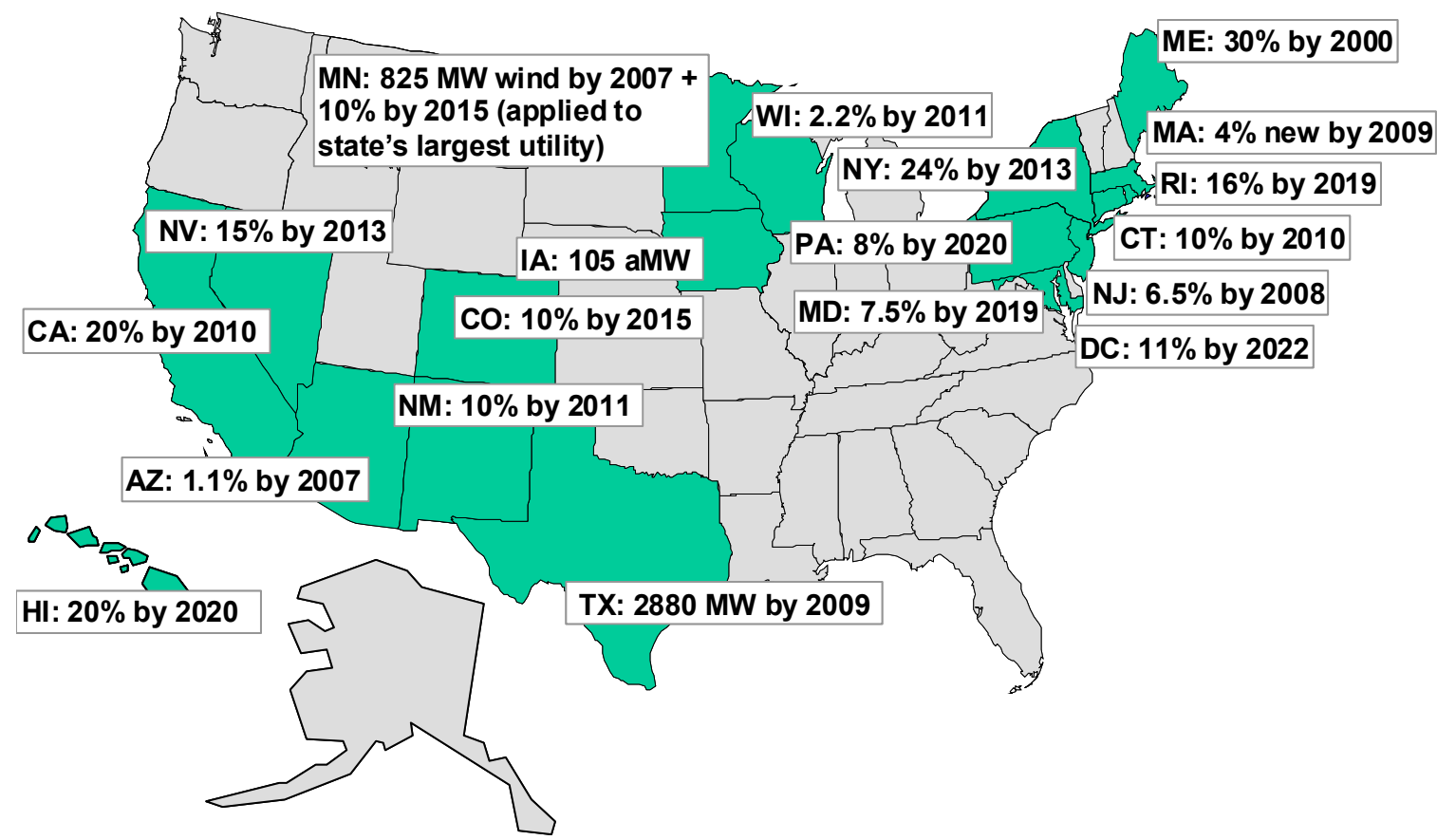

Figure 3.1 Existing state RPS policies in the US

\footnotetext{
7 In addition, 14 states had developed renewable energy funds, often funded through a small surcharge on retail electricity rates, totaling over $\$ 300$ million in support of renewable energy.
} 
A number of these policies were developed as a component of electricity reform legislation in the late 1990s. In more recent years, however, RPS policies have increasingly been developed on a stand-alone fashion. Increasingly, the motivations for establishing RPS policies have gone beyond environmental issues, to include local economic development and mitigation of fossilfuel price risk.

Figure 3.2 identifies when state RPS policies have been established (or substantially revised) in the US, and illustrates the fact that these policies are a relatively new occurrence in the US but that their popularity continues to grow.

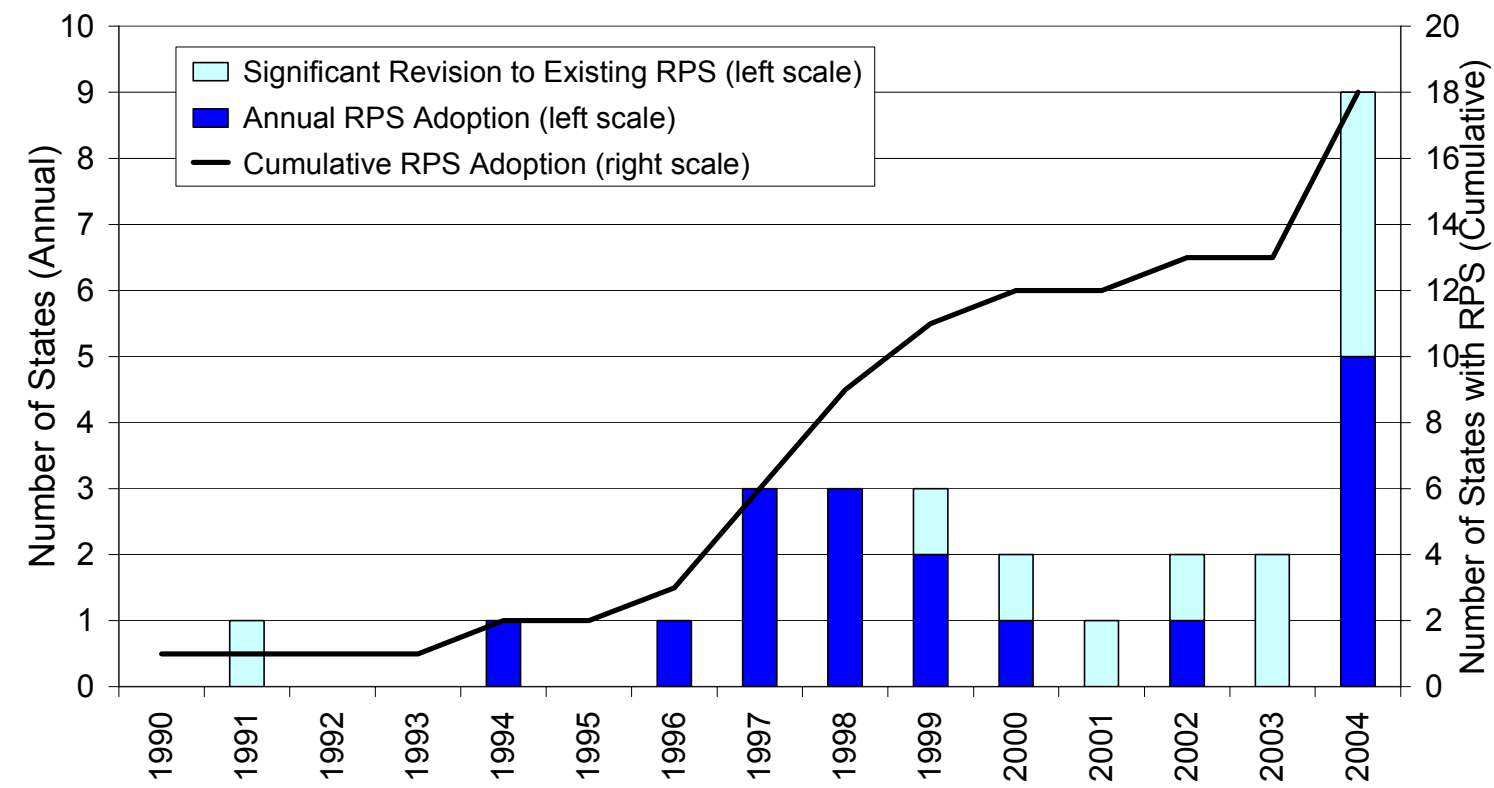

Figure 3.2 The date of adoption of, or major revision to, state RPS policies

Source: Lawrence Berkeley National Laboratory

It is frequently said that states serve as 'laboratories' for policy experimentation, and this is certainly the case with RPS programs. As detailed in Wiser et al. (2004), the design of state RPS programs varies considerably across states, including: the percentage standards and their duration, resource and geographic eligibility rules, how existing renewable generating stations are treated, the structure of the RPS and whether multiple purchase 'tiers' are required, on whom the RPS applies, whether TRECs are used to verify compliance, enforcement and flexibility mechanisms, cost caps, and whether the RPS includes renewable energy contracting standards. Table 3.2 illustrates some of these differences for the RPS policies in the states of California, Texas, Nevada, and Massachusetts.

\section{Europe}

Consideration of obligation systems began in Europe in the late 1990s. The obligation/TREC concept was supported in 1999 by DG Competition and former Energy Commissioner Papoutsis (European Commission, 1999), because of its compatibility with market liberalisation. In addition, wind power producers particularly in the UK had high expectations of an instrument that might reduce their dependency on direct government funding, and that might be profitable if TREC prices were high. (Lauber, 2004). Note, however, that in areas where successful feed-in tariff systems were operating (e.g., Germany, Denmark), wind power producers have been openly hostile towards obligation systems. The Danish government, for example, initially planned to introduce an obligation/TREC system to replace its increasingly costly feed-in tariff system, but later withdrew those plans in part because of industry opposition. 
The first government to implement an obligation/TREC system in Europe was the UK, followed by regions in Belgium (Flanders and Wallonia) and Italy, where it also replaced a feed-in tariff system. More recently, Sweden and Poland have followed, as illustrated in Figure 3.3.

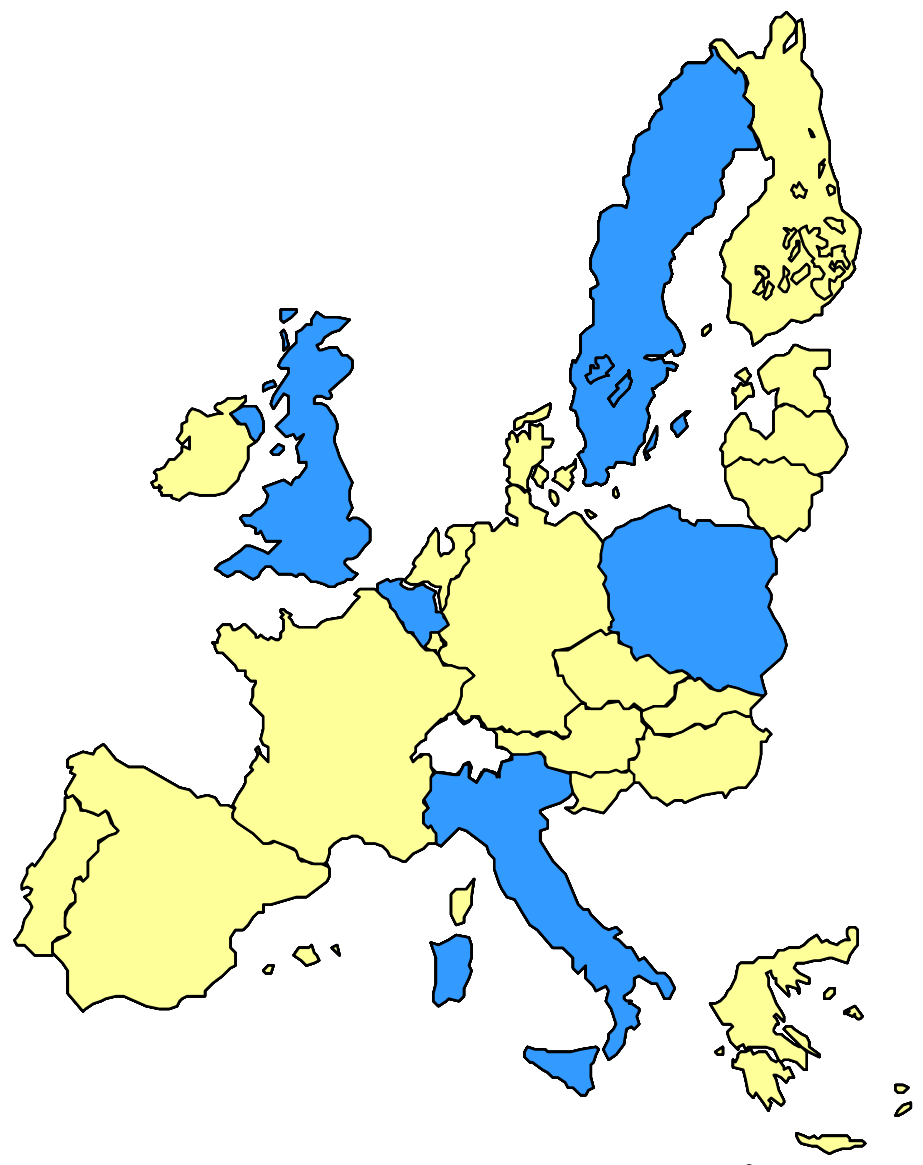

Figure 3.3 Overview of renewables support schemes in the EU-25

Note: dark - quota obligation; light - feed-in tariffs.

In the process of preparing the Renewables Directive 2001/77/EC, there appeared to be widely diverging opinions on which type of support scheme was to be preferred for Europe: obligations or feed-in tariffs. Therefore, the decision was postponed until October 2005, when the Commission is to present a report on experiences with the different mechanisms. However, subsequent communications from the Commission have indicated that a harmonisation proposal at this stage is unlikely.

\section{Australia}

Australia was one of the first countries to introduce an obligation system. In April 2001 the Mandatory Renewable Energy Target (MRET) was introduced as an instrument to increase the contribution of renewable sources to Australia's electricity demand. The MRET is aimed at reducing both greenhouse gas emissions and developing the renewable energy industry. The MRET requires 9,500 GWh per year of additional renewable electricity in the period 20102020, compared to 1997 levels. For the years until 2010, interim targets have been set. The MRET is backed by a system of TRECs.

In 2003, the MRET was reviewed by an independent panel that concluded that MRET was meeting its objectives. The interim targets for the first two years $(2001,2002)$ had been exceeded and the industry was well on the way to meeting the targets for the third and fourth years. In a response to the review, the Australian Government reconfirmed its commitment to

\footnotetext{
8 The graph reflects the announcement made in April 2005 that Ireland intends to change the support mechanism from a tendering system to feed-in tariffs (ENDS, April 11, 2005).
} 
the MRET scheme at the current level of $9,500 \mathrm{GWh}$ by 2010. It did not increase the target beyond 2010, as recommended by the review panel. As a result, some in the renewable energy industry have questioned whether the existing system can support a growing and thriving renewable energy sector. Other changes were also announced as a result of the review to enhance market transparency, increase opportunities for bio energy and solar technologies, improve business certainty, and encourage innovation through recognising emerging renewable electricity generation technologies.

\section{Japan}

In 1999, the Japanese Parliament started to discuss the most appropriate instrument for promoting renewable energy. Initially, a draft legislation based on the introduction of a feed in tariff system was proposed, but after the Ministry of Economy, Trade and Industry withdrew its support for the feed in system, new legislation based on the RPS approach was approved.

The Japanese Renewable Portfolio Standard came into force on 1 April 2003. The RPS places an obligation with the electricity suppliers to supply $1.4 \%$ of total electricity consumption from renewable sources by 2010. The intermediate target set for 2003 amounted to $3.3 \mathrm{TWh}$, which was exceeded by .7 TWh. Most important renewable sources are bio energy, small hydro and wind.

The first, although limited, experience with the Japanese RPS indicates that the way the system has been designed has a number of weak points resulting in poor system performance. The main problems are:

1. The target is too low to attract substantial investments in new renewable energy technologies.

2. The liquidity of the market is a problem because electricity is supplied by a limited number of companies who have monopoly power within their own supply area and thus dominate the certificate market..

3. The banking and borrowing provisions in the system are too broad causing instabilities in the green certificate price.

In summary, the current design of the Japanese RPS system does not yet provide the necessary incentives for creating new renewable energy capacity. The certificate market is not transparent, creating uncertainties among potential investors. Strategic behaviour of electricity suppliers further adds to the instability of the certificate price, hampering investments in new renewable technologies.

\subsection{Key elements of existing obligation systems}

As a first step in the review of obligation systems currently implemented in the USA and Europe, this section presents an overview of the key design elements of these systems. Table 3.1 presents, in a summarised way, the information obtained for the systems implemented in the states of California, Texas, Nevada, and Massachusetts. ${ }^{9}$ Table 3.2 gives similar information for the systems implemented in Sweden, the UK, Belgium (Wallonia and Flanders regions) and Italy.

9 A complete summary of the design of all 18 state RPS policies is not provided here. The four states selected are among the most significant of the US RPS policies. 
The following information on the design of the TREC system has been collected:

- Start date: the date on which the renewable energy purchase obligation begins.

- Obligated actor: the body where the renewable energy purchase obligation is placed. This is usually retail electricity suppliers, but in some cases the obligation may be imposed on the producers or consumers.

- Quantitative obligation: the obligation can be expressed as a certain proportion of total electricity consumption, as an absolute amount in $\mathrm{kWh}$, or as an absolute amount in MW.

- Issuing body: if applicable, the independent body responsible for setting up the TREC system and for issuing, registering and redeeming TRECs. This entity usually is a public body or authority.

- Eligible resource: the renewable energy technologies and resource eligible under the obligation.

- Banking: if allowed TRECs do not have to be consumed in the current compliance period but can be kept in an account and used for compliance with obligations in future years.

- Borrowing: if allowed the current obligation can (partly) be met by future generation of renewable electricity.

- Minimum price: the price guaranteed by the Government at which TRECs can be sold and meant to create a minimum level of price support for eligible renewable generators.

- Penalty for non-compliance: paid by the obliged actor if the obligation is not met. Depending on the design, this penalty can set the maximum price of a TREC or of renewable electricity purchased under the obligation.

- Period of validity: this is the period in number of years the TREC can be used for showing compliance with the obligation. Effectively this period is equal to the period banking is allowed.

- International (or interstate) trade; trade of TRECs or renewable electricity between countries or states. At the moment, in Europe imported TRECs can not be used for meeting the obligation. In the US, trade between some states is allowed.

- Treatment of existing plants: in some cases existing RES-E plants are not eligible under the obligation system because supporting those plants would not lead to the creation of additional RE capacity.

- Use of penalty revenues: usually the penalties collected from non compliance are used for one or more of the following purposes: i) a renewable energy fund; ii) recycled back to the actors who have complied with their obligation; and iii) general governmental purposes.

- Cost recovery method: the incremental costs for RES-E production is usually recovered through a surcharge on the electricity tariff. 
Table 3.1 Key design elements for a Select group of state RPS policies

\begin{tabular}{|c|c|c|c|c|}
\hline Element & California & Texas & Nevada & Massachusetts \\
\hline Starting date & 2003 & 2002 & 2003 & 2003 \\
\hline Obliged actors & IOUs and ESPs & IOUs and ESPs & IOUs and ESPs & IOUs and ESPs \\
\hline Quantitative obligation & $\begin{array}{l}\text { Min. } 1 \% / \text { year } \\
\text { increasing to } 20 \% \text { by } \\
2017 \text { (with state goal } \\
\text { to accelerate to } 2010 \text { ) }\end{array}$ & $\begin{array}{l}1280 \mathrm{MW} \text { by } 2003 \\
\text { rising to } 2880 \mathrm{MW} \text { by } \\
2009, \text { translated to } \\
\text { energy targets }\end{array}$ & $\begin{array}{l}5 \% \text { in } 2003 \text { growing } \\
\text { to } 15 \% \text { by } 2013(5 \% \\
\text { of target must be from } \\
\text { solar) }\end{array}$ & $\begin{array}{l}4 \% \text { by } 2009 \text { with } \\
\text { intermediate targets; } \\
\text { may increase after } \\
2009\end{array}$ \\
\hline Issuing body & $\begin{array}{l}\text { TRECs not currently } \\
\text { allowed; regulator } \\
\text { tracks compliance; } \\
\text { ultimately WREGIS }\end{array}$ & $\begin{array}{l}\text { ERCOT Independent } \\
\text { System Operator }\end{array}$ & $\begin{array}{l}\text { Nevada Public } \\
\text { Utilities Commission } \\
\text { (non-electronic TREC } \\
\text { tracking) }\end{array}$ & $\begin{array}{l}\text { New England } \\
\text { Generation } \\
\text { Information System }\end{array}$ \\
\hline Eligible resources & $\begin{array}{l}\text { Solar, wind, } \\
\text { geothermal, ocean, } \\
\text { biomass, small hydro } \\
\text { and MSW (many } \\
\text { resources with limits) }\end{array}$ & $\begin{array}{l}\text { Solar, wind, } \\
\text { geothermal, ocean, } \\
\text { biomass, hydro }\end{array}$ & $\begin{array}{l}\text { Solar (including solar } \\
\text { heat), wind, } \\
\text { geothermal, biomass, } \\
\text { MSW, waste heat, } \\
\text { certain hydro }\end{array}$ & $\begin{array}{l}\text { Solar, wind, ocean, } \\
\text { low-emission, } \\
\text { advanced biomass }\end{array}$ \\
\hline Banking & Indefinite & 2 years & 4 years & $\begin{array}{l}\text { Over-compliance can } \\
\text { be banked to next } \\
\text { year, with } 30 \% \text { limit }\end{array}$ \\
\hline Borrowing & $\begin{array}{l}\text { Deficit of } 25 \% \text { to next } \\
\text { year for } 3 \text { years } \\
\text { allowed automatically }\end{array}$ & $\begin{array}{l}10 \% \text { shortfall before } \\
2003 \text { allowed }\end{array}$ & None & None \\
\hline Minimum price & None & None & None & None \\
\hline $\begin{array}{l}\text { Penalty for non } \\
\text { compliance }\end{array}$ & $\begin{array}{l}\$ 50 / \mathrm{MWh} \text {, with cap } \\
\text { of } \$ 25 \mathrm{million} / \mathrm{yr}\end{array}$ & $\begin{array}{l}\$ 50 / \mathrm{MWh} \text { or } 200 \% \text { of } \\
\text { average TREC price }\end{array}$ & $\begin{array}{l}\text { Admin. fines can be } \\
\text { applied, but utilities } \\
\text { can apply for } \\
\text { exemptions }\end{array}$ & \$ 51.4/MWh ACP \\
\hline Period of validity & N/A & 3 years & 5 years & 1 year \\
\hline Inter-state trading & $\begin{array}{l}\text { RES-E delivered into } \\
\text { state is eligible }\end{array}$ & $\begin{array}{l}\text { Out-of-state RES- } \\
\text { Effectively precluded }\end{array}$ & $\begin{array}{l}\text { RES-E located within } \\
\text { or near state allowed, } \\
\text { with restrictions }\end{array}$ & $\begin{array}{l}\text { RES-E located within } \\
\text { or delivered to New } \\
\text { England is eligible }\end{array}$ \\
\hline $\begin{array}{l}\text { Treatment of existing } \\
\text { plants }\end{array}$ & Yes & $\begin{array}{l}\sim 880 \mathrm{MW} \text { of existing } \\
\text { RE can meet RPS, but } \\
\text { not trade TRECs }\end{array}$ & Yes & No \\
\hline $\begin{array}{l}\text { Certificate price in } \\
\text { most recent years }\end{array}$ & $\begin{array}{l}\text { N/A; bundled long- } \\
\text { term RE sales price } \\
\text { avg. } \sim 40-50 / \mathrm{MWh}\end{array}$ & $\begin{array}{l}\text { \$14/MWh for short- } \\
\text { term TRECs }\end{array}$ & $\begin{array}{l}\text { Bundled long-term } \\
\text { RES-E sales price } \\
\text { avg. } \sim \$ 45-55 / \mathrm{MWh}\end{array}$ & $\begin{array}{l}\$ 51 / \mathrm{MWh} \text { for short- } \\
\text { term TRECs }\end{array}$ \\
\hline $\begin{array}{l}\text { Use of penalty } \\
\text { revenues }\end{array}$ & General purposes & General purposes & General purposes & Support for RE \\
\hline Cost recovery method & $\begin{array}{l}\text { Costs recovered } \\
\text { though rates, and } \\
\text { through separate SBC }\end{array}$ & $\begin{array}{l}\text { Costs recovered } \\
\text { though rates }\end{array}$ & $\begin{array}{l}\text { Costs recovered } \\
\text { though rates }\end{array}$ & $\begin{array}{l}\text { Costs recovered } \\
\text { though rates }\end{array}$ \\
\hline Other key details & $\begin{array}{l}\text { SBC revenue used to } \\
\text { support } \mathrm{RE} \text { contracts } \\
10+\text { year contracting } \\
\text { requirement }\end{array}$ & & $\begin{array}{l}10+\text { year contracting } \\
\text { requirement }\end{array}$ & \\
\hline \multicolumn{2}{|c|}{$\begin{array}{l}\text { ACP: Alternative compliance payment } \\
\text { ESP: Competitive energy service provider } \\
\text { SBC: System benefits charge }\end{array}$} & $\begin{array}{l}\text { ERCOT: Electric Reliabil } \\
\text { OU: Investor-owned util } \\
\text { NREGIS: Western Rener }\end{array}$ & $\begin{array}{l}\text { ility Council of Texas } \\
\text { lity } \\
\text { wable Energy Generati }\end{array}$ & System \\
\hline
\end{tabular}




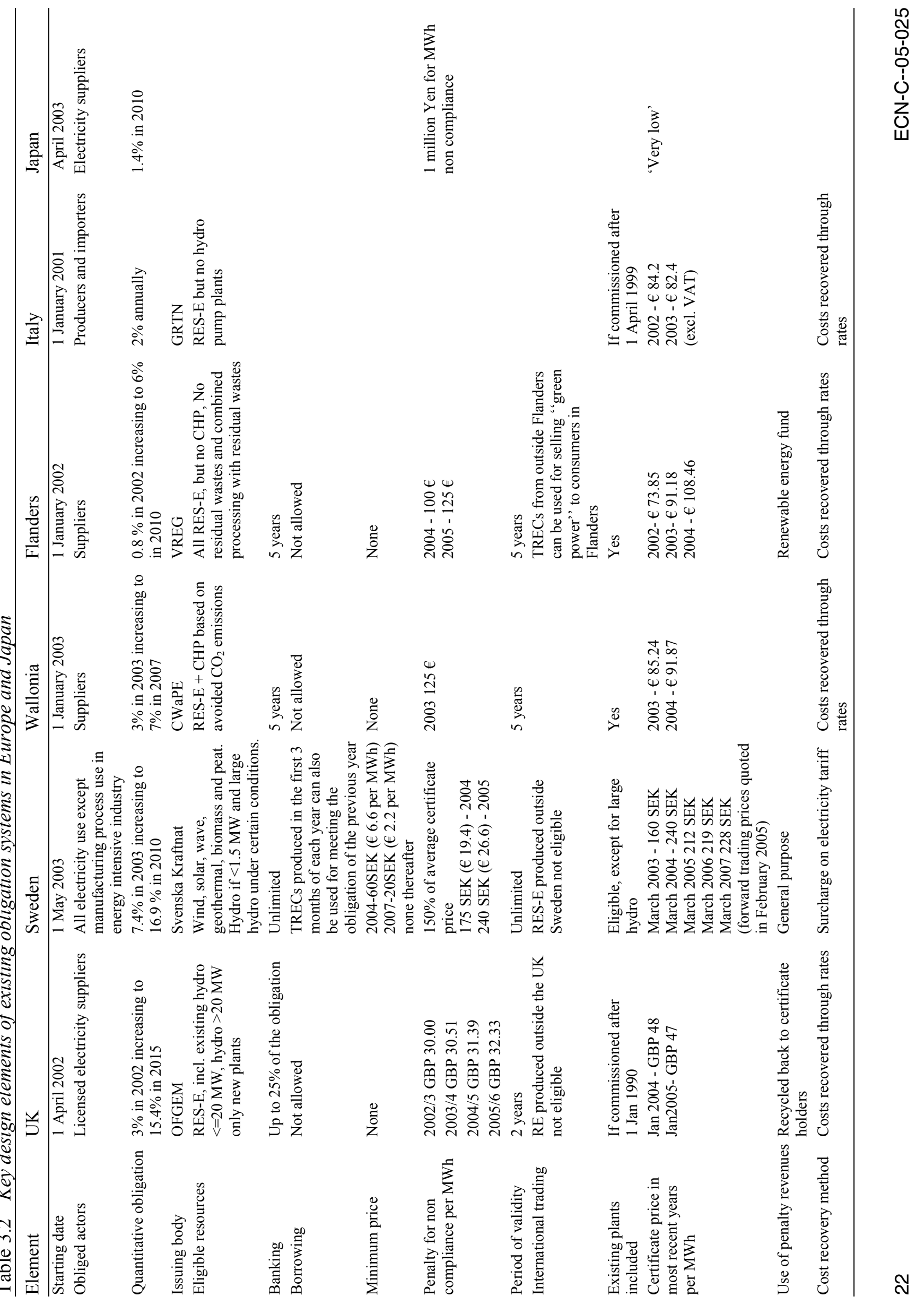




\subsection{Criteria for evaluating the performance of obligation schemes}

In Section 3.2, an overview of key information on the design of the obligation/TREC system in Europe and the USA is given. In Chapters 4, 5 and 6, a more detailed assessment of the performance of the obligation systems in these countries is presented based on the following evaluation criteria:

- Effectiveness: Defined in terms of achieving a large amount of RES-E capacity added or production generated, this indicator relates to the quantitative impact of the obligation system in promoting new renewable energy.

- Market efficiency: Obligation systems are often argued to result in cost competition and therefore a minimization of costs in supporting renewable energy. In principle, well defined obligation markets should lead to such competition and therefore an efficient allocation of resources in support of renewable energy. Do obligation/TREC markets function well in practice, minimizing the cost of supporting renewable energy?

- Certainty for RES-E industry: Growth of RES-E capacity ultimately depends on the decisions of individual investors. This criterion assesses whether or not the system is perceived as stable in the short and long term from the perspective of investors.

- Cost effectiveness: This measure is defined as the costs per kWh of RES-E, including the 'dead weight' costs such as transaction costs, overcompensation of certain market actors etc.

- Stakeholder support for the system: The success of the obligation system may depend, in part, on the level of support the system has from various stakeholders. Widespread stakeholder support may also indicate a well-functioning policy.

- Equity: From a government point of view and for long term sustainability of the system, a fair distribution of costs and benefits of RES-E implementation over various stakeholders is important.

A theoretical evaluation of obligation systems in comparison to other support schemes, based on these criteria, can be found in (Van Dijk et al, 2003). 


\section{Experience in the UK}

\subsection{Introduction}

The electricity market in the UK consists of three distinct markets: (1) England \& Wales, (2) Scotland, and (3) Northern Ireland. The interconnection between these three distinct markets has traditionally been limited, but the UK government and the energy regulator are working to integrate the markets in the British mainland (England \& Wales and Scotland) as interconnection capacity and trade has increased. Betta, the British Electricity Trading and Transmission Arrangements, effectively unifies the markets on the British mainland and is likely to come into effect from 1 April 2005. Interconnection with Northern Ireland is still very limited, and the British and Northern Irish markets are unlikely to be fully integrated in the short- to mediumterm.

The UK has provided support for renewable energy developments for many years. In 1990, the government launched several rounds of competitive bidding for renewable energy contracts, known in England \& Wales as the Non Fossil Fuel Obligation (NFFO). This support mechanism only showed limited success. The government therefore decided to replace this scheme and introduced a new, more market-driven support mechanism, which places an obligation on electricity suppliers to ensure that a minimum percentage of the power they sell comes from renewable energy sources. This obligation system is known in England \& Wales as the Renewables Obligation (RO) and in Scotland as the Renewables Obligation Scotland (ROS). From 1 April 2005 the Northern Ireland Renewables Obligation (NIRO) is also expected to be in force. There was fungibility between the obligation systems across Great Britain $(\mathrm{GB})^{10}$ from the launch, on 1 April 2002, and from 1 April 2005 there is likely to be full recognition and tradability under the obligation systems across all three UK markets.

The obligation in the UK is placed on licensed electricity suppliers, who have to surrender TRECs, called Renewable Obligation Certificates (ROCs) ${ }^{11}$, or pay a penalty to comply with the legislation. The obligation level (in GB) started at 3\% of electricity supplied in 2002/2003 and rises to $10.4 \%$ in $2010 / 2011$. The obligation periods run from 1 April to 31 March the following year. Initially, the $10.4 \%$ obligation level was set to continue at that level until the end of the Renewables Obligation (RO) in 2027. However, it was realised that in order to further encourage investments, obligation levels needed to be fixed at higher levels for the period after $2010 / 2011$. The targets are now set to increase to $15.4 \%$ by $2015 / 2016$. The obligation levels are ambitious, and the system design only guarantees high ROC prices if there is a large shortfall compared to the target.

ROCs are issued to eligible RES-E plants by OFGEM, the issuing body, who also operates an electronic registry. The definition of eligible renewable energy sources follows the Renewables Directive, with exceptions for hydropower, waste and co-firing of biomass ${ }^{12}$.

England \& Wales and Scotland.

11 SROCs and NIROCs in Scotland and Northern Ireland, respectively.

12 The RO also adds that 'only stations first commissioned or re-equipped on or after 1 January 1990 (except micro hydro and co-firing station) are eligible'. In practice, this means that virtually all renewable energy plant are eligible. 
Only existing hydro plant of $20 \mathrm{MW}$ or less declared net capacity are eligible, as well as any plant commissioned after the start of the RO. Pyrolysis, gasification and anaerobic digestion of mixed waste is eligible, but only the non-fossil derived energy counts. All energy recovery from energy crops, agricultural waste $\&$ forestry materials are eligible, but may only be co-fired until 31 March 2016.

Energy recovery from waste which is purely biomass is also eligible, but when co-fired needs to be mixed with at least $25 \%$ energy crops from 1 April 2009, 50\% energy crops from 1 April 2010, 75\% energy crops from 1 April 2011, and is no longer eligible after 31 March 2016. No supplier may surrender co-fired certificates for more than $25 \%$ of its obligation level. Suppliers also have a maximum of $25 \%$ on using 'banked' certificates awarded in the previous period. These co-firing rules come from the recent Renewable Obligation (Amendment) Order 2004, which changed the original rules in response to market concerns. First, the maximum contribution from co-firing was reduced from $25 \%$ to $10 \%$ in the short term in order to reduce the potential price impact of co-firing. However, co-firing has been allowed to continue for an additional 5 -year period after 2010/11 at a reduced share of 5\%, which allows generators to recoup some of the investment required to convert to co-firing. Secondly, the 2004 Amendment delays the requirement for a high share from energy crops until 2011/12, and it introduces this requirement more gradually; this amendment was required because an insufficient amount of energy crops are expected to be available in the short term.

The buy-out payment for suppliers who cannot comply with the obligation level was set at $£ 30 / \mathrm{MWh}$ in 2002/2003, increasing with the retail price index. ${ }^{13}$ A defining feature of the UK obligation system is the fact that the buy-out payments are 'recycled back' to those suppliers who surrendered ROCs. This means that while the cost of the obligation to the end consumer is capped, the value of the certificates may exceed this cap. Indeed, in the first year, the average traded price of ROCs was $£ 47-48 / \mathrm{MWh}$. Third compliance period ROCs are currently trading at $£ 47 / \mathrm{MWh}^{14}$, while prices topped $£ 52 / \mathrm{MWh}$ earlier in the third compliance period.

While still only less than three years in operation, the Renewables Obligation Order 2002 has already seen a number of changes proposed and implemented. The first changes were proposed one year after the start of the scheme and were implemented through the Renewables Obligation (Amendment) Order 2004. This introduced a lower limit for small-scale generators and changes to penalty payments, in addition to the changes noted above. The next set of changes has been proposed in the Renewable Obligation Order 2005 Statutory Consultation, and will be implemented by 1 April 2005. The latest changes will include the confirmation of the target increase by 2015 , changes to the recycling fund, and extension of the mechanism to smaller scale generators, as well as the introduction of the Northern Ireland Renewables Obligation.

13 The buy-out was set at $£ 30.51$ in $2003 / 2004$, and is $£ 31.59$ for the $2004 / 2005$ period.

14 Auction of Renewable Obligation Certificates be NFPAS - Results, NFPA, 20 January 2005. 
- Large hydro (>20 MW) plants commissioned after 1 April 2002.

- Mixed waste is only eligible using advanced energy recovery processes (pyrolysis, gasification and anaerobic digestion).

- Energy crops, agricultural waste \& forestry material are eligible. However, if co-fired only until 31 March 2016.

- Waste which is purely biomass is treated the same as energy crops, but if co-fired requires a minimum percentage energy crops.

Old rules:

- Energy crops co-firing: The minimum percentage from energy crops is $75 \%$ from 1 April 2006.

- Co-firing: Any co-fired certificates are only eligible for up to $25 \%$ of the suppliers' obligation, until 31 March 2011.

New rules:

- Energy crops co-firing: The minimum percentage energy crops is $25 \%$ from 1 April 2009, 50\% from 1 April 2010, 75\% from 1 April 2011.

- Co-firing: Any co-fired certificates are only eligible for up to $25 \%$ of the suppliers' obligation, until 31 March 2006, $10 \%$ until 31 March 2011, and 5\% until 31 March 2016.

\subsection{Evaluation of the performance of the obligation scheme}

\subsubsection{Effectiveness}

The Renewable Obligation has only been in place since 1 April 2002 in GB and is likely to come into operation in Northern Ireland on 1 April 2005. Given investment lead times and the time-consuming planning process in the UK it is impossible to say with great certainty the extent to which the Renewables Obligation is leading to the development of additional renewable capacity or renewable electricity generation. However, capacity and generation have increased markedly.

Figure 4.1, below, shows the increase of electricity generation by ROC-eligible plant in the UK since 1999. The annual growth rate has significantly increased since the introduction of the obligation. The data published by the issuing body also show a marked increase of ROCs issued on a month-by-month basis since the start of the scheme. ${ }^{15}$ However, the obligation has not yet been able to stimulate many new large-scale developments. This is due both to the short term since the start of the RO in 2002, and the difficulties of the obligation for developers.

15 This monthly data is not presented here, but is available on the OFGEM website: http://www.ofgem.gov.uk/temp/ofgem/cache/cmsattach/9797_ro_06_jan_05.xls. 


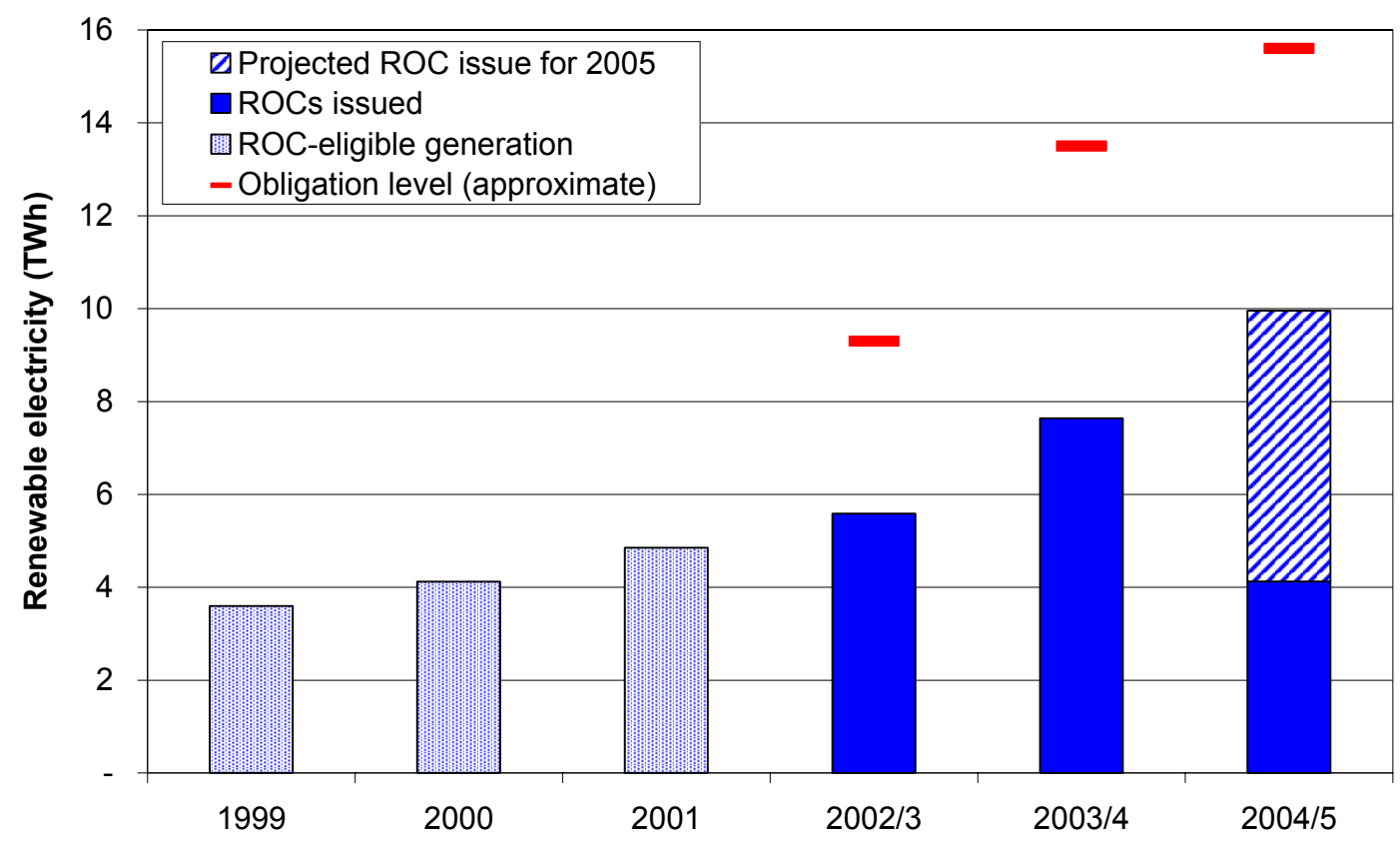

Figure 4.1 Renewable electricity generated in the UK on a ROC-eligible basis

Despite growing rapidly, Figure 4.1 shows that that the level of the obligation is far higher than the generation from renewables achieved to date. In actual fact, the ROC system has so far been built around the premise that the obligation will not be met, in order to underpin the market price of the certificates. ${ }^{16}$ Indeed, market players predict that in the commitment period when the target may be hit, the price of the certificates will fall dramatically. While the existence of a voluntary market for green power, as well as the possibility to convert ROCs to UK emission allowances ${ }^{17}$ will help to stop the price dropping to zero, the effect on the ROC market is that investors will only take into account value of ROCs in years when they predict that the supply of ROCs will be significantly lower than the target.

The value of ROCs is therefore likely to fall drastically when the target is close to, or even perceived as being close to, being met. This in turn is likely to put a break on the new-build of renewable capacity, and thus preserve the higher price of ROCs. Generators will not want the targets to be met as their value is maximised by missing the target by a large margin. The margin by which the target is missed provides the basis for the value of the tradable certificates in the market. This price is currently some $50 \%$ above the penalty payment, and at $£ 47$ /MWh provides one of the highest incentives in Europe.

Figure 4.2 shows the compliance levels for the main obliged suppliers in England \& Wales in the first year of the obligation. It shows clearly that supply companies followed different strategies towards the obligation, with some seeking full compliance and others buying out for their full obligation. Average compliance in the first period was about $60 \%{ }^{18}$. The figure also compares the compliance level with the size of the supply company, which may represent one measure of the capacity of the company to deal with the additional/new requirements of a policy like the Renewables Obligation. If the obligation is too cumbersome, smaller companies are likely to prefer to pay the buy-out, while larger companies may be more likely to comply by surrendering certificates.

16 Of course, this was never a stated aim of the RO, but it has since been recognised by policy makers that the system only acts as an effective support instrument as long as the target is not met. The RO is one of the important instruments for meeting the UK's indicative target of the EU Renewables Directive, however, given the exclusion of large hydro and restrictions on biomass/waste, the indicative target can be met even if the RO is not fully met.

17 That is allowances for the UK emissions trading scheme, not the EU ETS.

18 Average compliance levels in the second and third period are in the same order, around $60 \%$. 
Most of the larger suppliers did submit ROCs during the first period, but approximately half of the smallest companies decided not to comply and instead paid the buy-out. This comparison is not conclusive, however, both because this only covers the first year and because companies of all sizes were compliant and non-compliant.

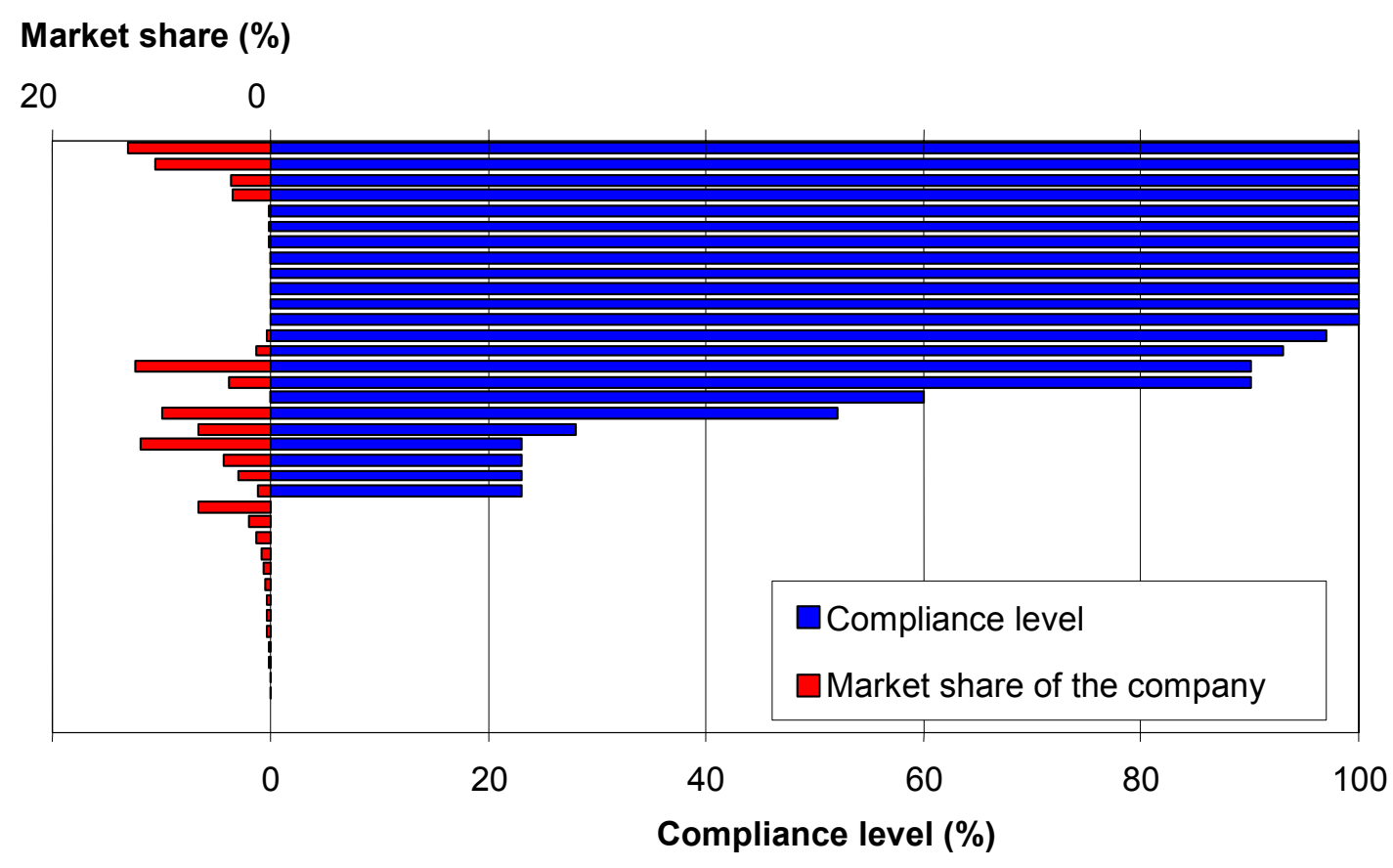

Figure 4.2 Comparison of the percentage of each supplier's RO that was satisfied by ROCs or SROCs in 2002/3

Source: The Renewables Obligation: Ofgem's first annual report, February 2004.

From the perspective of the renewable generators, the Renewable Obligation is now considered to be generally effective. The mechanism allows developers to finance new renewable plant. However, whilst larger companies have been able to use their balance sheet in order to invest in new renewable energy capacity, smaller developers have found it more difficult to raise finance from the banking sector. Initially there were teething problems with the financial sector being unclear about the system and the government's long-term commitment to it. However, the government has been very clear that it is committed to the obligation as a long-term strategy, and extended and increased the targets until 2015/16. Nonetheless, the fact that the system is still new and liquidity is limited means that the financial sector has been wary to lend money.

There are also many other financing difficulties and barriers faced by developers which are not due to the type of support mechanism in place, for instance due to long permitting procedures. Some of these barriers are being addressed by government.

\subsubsection{Market efficiency}

Given the limitations of the ROC market in terms of number of obliged parties, liquidity, and difficulties in long-term contracting, the market efficiency has also been limited. While it is possible for renewables generators to negotiate long-term contracts, this has been very limited and difficult. Long-term contracts typically contain risk-sharing arrangements that do not reward the generator with the full value of the ROC. However, supply companies contracting for the longterm do assume a large risk. Some long-term contracts give fixed prices for ROCs and some- 
times also physical delivery. However, most contracts establish indices such as the buy-out level, recycle payment and the electricity price, with both parties sharing the risks and rewards. The buy-out penalty level roughly defines the maximum cost of the obligation to the consumer. However, the recycling of the buy-out payment has introduced an additional market incentive to generate renewable electricity, as the recycle increases the value of a ROC over and above the buy-out level. However, it has also introduced additional complexity and additional risks, which may not lead to greater income to renewable generators. Additionally, the recycle payment may only be received between 1 and 2 years after the date of generation of the ROC, which does not help the cashflow situation and bankability for many developers.

From the perspective of renewable energy developers, it is important to be able to show longterm contracts in order to raise finance. This is particularly the case for independent developers. In this respect the ROC market is more favourable for vertically integrated electricity companies who are able to develop RE projects and also have a supply license (and thus an obligation level). Generally, long term contracts in the ROC market are for about 5 years, but contracts of up to 10 years are known to have been negotiated and concluded, but even that is only half the lifetime of the project. However, long-term contracts are considered 'expensive' for (independent) developers, with forward ROC prices substantially below the current spot price.

As shown in

Figure 4.2, however, many of even the smallest suppliers manage to comply with the obligation through surrendering ROCs, and the risks and complexities of this market therefore cannot be considered prohibitive for suppliers.

The ROC price is influenced by a number of factors, but most importantly the expected shortfall in compliance with the obligation. A second very important aspect was highlighted by the bankruptcy of two obliged suppliers in the first compliance year, leaving the buy-out fund dramatically short, and thus depressing the value of ROCs. The ROC price still includes a risk premium for further problems with buy-out and recycle payments. Spot prices are also affected by the auction price at the regular auctions of certificates derived from NFFO plants. And plans for new build have a direct impact on any longer-term contracts negotiated, as the negotiated price will be dependent on the expectations of the contracting parties of how short the market will be.

The market has already developed a number of derivatives for the ROC market, including forward streams, bundles (ROC plus underlying electricity and/or other attributes), and the recycle value. However, liquidity is limited because the market size and number of participants is small, and therefore the cost of such derivatives is high.

\subsubsection{Certainty for the renewable energy industry}

As explained above in Section 4.1 a number of changes have already been made to the Renewables Obligation. Whilst in some ways this unsettles the market, the long-term commitment of the government towards the obligation has always been clear. The most important change has been the confirmation of the increase in the targets between 2010/11 and 2015/16, as well as the aspirational target for 2020. This new level of the obligation has given greater confidence in the ROCs market and stimulated investments in renewable generation capacity. It is now clear that the obligation level is unlikely to be met until the target reaches a plateau, and that the value of ROCs is likely to remain above the buy-out penalty during that time.

Recent re-found confidence in the Renewable Obligation has reduced the risk premium and stimulated increased investment in the sector. While very hesitant at the start of the scheme, a number of banks are now actively looking at investing and becoming involved in the market. However, more ambitious targets again are required for the period after 2015/16, in particular for off-shore wind power developments which still have significant lead times. Indeed, for many 
large off-shore wind farms that are currently planned, the horizon is past 2015 already. The market is still under-performing due to the lack of longer-term targets.

The extension of the targets and the government's commitment has increased confidence in the market considerably. However, two further shorter-term uncertainties are shaping the market. First, market confidence is shaken by the various reviews that are taking place, despite the government stressing the limited scope of these reviews. Secondly, there is the threat of increased large-scale co-firing on the market price.

ROC prices have been relatively stable and are affected mainly by the level of new build and thus the predicted shortfall. There have been some variations with prices rising to a $£ 52 / \mathrm{MWh}$ high at the start of the third compliance period as the exact size of the recycle value became clear and risks diminished, though the price subsequently fell by $£ 5$ to $£ 47 / \mathrm{MWh}$.

\subsubsection{Cost effectiveness}

The cost to the end consumer so far has been relatively low, currently at some $0.15 \mathrm{p} / \mathrm{kWh}^{19}$, compared to their final prices (about $7.5 \mathrm{p} / \mathrm{kWh}$ for standard daytime electricity, exclusive of VAT). How much of this ends up with generators or is taken by the obliged parties is not easy to determine. In November 2004, electricity prices were in the region of $£ 24-£ 27 / \mathrm{MWh}$ and with the climate change levy (LECs) and other benefits prices were approximately $£ 30 / \mathrm{MWh}$. On top of this the current prices for third period ROCs were $£ 47 / \mathrm{MWh}$ for large volumes. However, small renewable energy generators were still being offered prices as low as $£ 45 / \mathrm{MWh}$ all in, including the electricity.

From a suppliers point of view, the maximum costs of the obligation should be about $£ 1.50$ per MWh supplied, without any market-related risks, by using the buy-out. It may be possible for some suppliers to take on more risk, whilst reducing the costs below that figure - in particular for vertically integrated electricity companies. It is not possible to say whether such cost savings are then passed on to the end consumer.

However, the RO is based on the assumption that all renewable technologies can compete, which is not the case in the UK. In particular, the system does not sufficiently support emerging and still non-competitive technologies, such as offshore technologies and biomass, and so other support mechanisms have been introduced to support some of these.

\subsubsection{Stakeholder support for the system}

Renewable energy stakeholders generally support the Renewables Obligation as a useful tool for increasing renewable electricity generation. This support for the RO may be seen as a preference for the RO over the NFFO/SRO system that was in place before 1 April 2002. Many problems existed with the NFFO/SRO, including the randomness of the timing and details of the solicitation rounds, as well as the uncertainty for those bidding in those solicitations. The RO has solved some of these problems. The general support for the RO is also based on the belief that other alternatives such as feed-in tariffs and investment subsidies are not likely to be sustainable in the medium to long term.

However, there are conflicts between the various stakeholders within the RO. Coal-fired generators, for example, have much to gain from liberal rules on co-firing, while this could undermine the price for other renewable energy generators. These internal conflicts have become more apparent since the start of the obligation in 2002.

19 This is based on the current buy-out price of $£ 31.59 / \mathrm{MWh}$, and obligation level of $4.9 \%$, leading to a maximum cost - if a strategy of $100 \%$ buy-out is pursued by the supply company - of 0.154 pence $/ \mathrm{kWh}$. However, this additional cost is simply absorbed and not displayed separately on the bill. 


\subsubsection{Equity}

It is too early to say who gains and who loses most from the RO legislation. However, it is likely that smaller independent renewable energy developers are at a disadvantage compared to the large vertically integrated companies that also hold a supply license, as the latter also have an obligation level and can absorb the risk internally.

As mentioned above, developers feel that the long-term contracts that they need are potentially less profitable than simply selling ROCs in the short-term market, as the contracted forward ROC price is significantly below the spot price. However, suppliers argue that this is a fair risk premium given the state of the market.

Finally, given the transaction costs in the market, which is still not liquid enough, owners of large renewable energy plant have a distinct advantage over owners of small-scale installations.

\subsubsection{Other key issues}

A number of further issues need discussion: differences between technologies, the recycle fund, and the potential for double counting.

\section{Technology tiers}

In principle ROCs from any technology have the same value with one exception: ROCs from co-firing may only be used for part of the obligation, and thus the value of these ROCs is dependent on how close to the maximum allowed quantity of co-fired ROCs are generated. However, also for non-co-fired ROCs different prices may be offered on forward contracts, due to the risk perception associated with the intermittency of specific technologies.

Additionally, with regards to technology, it must be noted that the exclusion of large-scale hydro capacity resulted in the downsizing of a number of large-hydro plant prior to the start of the $\mathrm{RO}$ in order to become eligible. This is of course, counter to the objective of the RO.

\section{Recycle fund}

At the end of the first compliance period, two supply companies went into administration, leading to a large shortfall in the recycle fund. This caused great uncertainty in the market, and significantly reduced the value of a ROC. Several changes have already been implemented or are proposed in the reviews to resolve this issue. One such change is that late payments, including late buy-out and penalty payments, are also distributed along the same lines as the original recycle payment. A second change is that the currently-separate funds for England \& Wales and Scotland (and Northern Ireland from April 2005) are merged, leading to one single recycle payment as opposed to different levels if any shortfall occurs. Finally, it is proposed to mutualise the recycle fund, meaning that all participating suppliers are mutually liable for the buy-out payments, in order to secure the recycle value even if an obliged party goes into administration. However, this last proposed change is considered too complex by many and would actually damage the market. Further proposals include shorter obligation periods, thus reducing the size of the shortfall, and extending the recycle payment to anyone holding ROCs rather than only suppliers, thus reducing the market power of suppliers.

The complications with the recycle fund have led some suppliers to opt for $100 \%$ buy-out to reduce the risks they are exposed to. This, of course, is counter to the intention of the RO. 


\section{Double counting}

There exists a large potential for double counting ${ }^{20}$ in the UK system. This is particularly the case because of various parallel systems operating to increase renewable generation and reduce greenhouse gas emissions. With regard to emission reductions it is possible for ROCs to be converted to UK Emission Allowances. Additionally, the expected level of compliance with the RO may not be fully incorporated in the national allocation plan for the EU Emissions Trading Scheme. However, the double counting potential between renewables and emissions goes beyond the scope of this report.

The most serious potential for double counting exists because of the co-existence of ROCs, Renewable Energy certificate System (RECS) ${ }^{21}$, Renewable Energy - Guarantees of Origin (REGOs) ${ }^{22}$ and LECs. Most voluntary green tariffs are currently based on LECs, (Climate Change) Levy Exempt Certificates, which are issued to renewable generators, while ROCs from the same plant can be used to meet the RO. Similarly, Guarantees of Origin (GO, also known as RE-GO) may also be used for some purposes independent of the LEC and ROC. Double counting between the Obligation and green tariffs, therefore, is very likely.

\subsection{Conclusions and lessons learnt}

The Renewables Obligation is an effective support mechanism for renewables. It has created a market that offers one of the highest levels of support for renewable electricity in Europe, without causing high costs to the end consumers.

This high level of support is caused by the so-called 'recycle payment', i.e. the redistribution of the buy-out funds to suppliers who complied, effectively limiting the costs at the buy-out level, but allowing the price to be much higher depending on the level achieved compared with the target.

However, this same recycle payment also introduced an additional layer of complexity and uncertainty to the level of support received by the renewable generators, as the recycle payment is not known until the end of the compliance period. As a result, the price of ROCs is determined by the expected shortfall from the target, which is hard to estimate long in advance. This additional uncertainty in the market, therefore, makes it hard to close long-term contracts which developers generally require for financial closure, and is not beneficial to developers, in particular smaller independent developers. The bankruptcy of a number of suppliers in the first year, and the shock of the recycle shortfall has also affected confidence in the system.

Indeed, the recycle mechanisms while raising prices above the buy-out also has a negative effect on stimulating growth of capacity, as the nearer the target the lower the price per ROC, thus reducing the incentive for developers.

20 In the report (Uyterlinde et al, 2004), four classifications of multiple counting are presented: 1) multiple issue of TRECs for the same kWh; 2) multiple use of an individual TREC, 3) parallel use of TREC and other certificate; and 4) unintentional or fraudulent errors.

21 The RECS system is a harmonised European standard for handling TRECSs. It has been developed by a group of companies from the electricity sector and private consultancies and is supported by regulators of some Member States (www.recs.org).

22 The Renewables Directive stipulates that EU Member States are required to have legislation in place to establish a system that will enable RES-E generators to obtain RE-GOs for the electricity produced from their plants in response to a request. For a detailed discussion of the interactions between RE-GOs and the various support schemes currently in place in different Member States (see van der Linden et al, September 2004). 
Three key lessons can be learnt from the UK's experience to date:

- First, that changes to the system create uncertainty in the market and it is therefore important to get the design right at the start.

- Secondly, such a system should be kept as simple as possible, as complications add costs but may not add value to the renewables market.

- Thirdly, the absence of long-term targets and a strong commitment from government for the obligation reduces certainty for the industry, and halts investment in additional capacity. 


\section{Experience in Sweden}

\subsection{Introduction}

The Swedish quota obligation system came into force on 1 May 2003, as a result of an interparty agreement between the governing Social Democrats, the Center Party and the Left Party. The policy is part of the national energy policy targeting a transition towards a more sustainable energy system where nuclear power is phased out and fossil fuel use is limited (Swedish Government, 2002) ${ }^{23}$. The system was intended to replace all previous investment and production subsidies for renewable electricity technology ${ }^{24}$. The overall objective of the scheme is to increase the production of electricity from eligible renewable sources from $6.5 \%$ estimated for 2002 to $16.9 \%$ in 2010 (for the time being; future increases are possible). This corresponds to $10 \mathrm{TWh}$ of new RES electricity production. The objective was also to introduce competition between different RES eligible for certificates. As expected, this has resulted in more electricity from biomass-based Combined Heat and Power (CHP), whereas the installation of wind power turbines has slowed.

Under this system, all electricity consumers (except energy-intensive industry) are required to buy a share of electricity from RES-E, which corresponds to a percentage of their electricity use (8.1\% in 2004). The quota obligation is raised each year. Electricity suppliers are required to manage the quota obligations of the consumers and hence buy certificates from producers. Electricity users have the right to manage their own quota obligation. Consumers that do not comply have to pay a penalty, which amounts to $150 \%$ (starting in 2005) of the average certificate price during the previous accounting period. The penalty thus sets a moving ceiling price.

Eligible RES include existing and new wind, biomass, geothermal, solar, and hydropower plants less than 1.5 MW and wave power (and peat since 1 April 2004). All new hydropower is eligible in principle, but large-scale plants are prevented by legislation that protects unexploited rivers. Existing hydropower below $15 \mathrm{MW}$, and production increases from upgraded existing hydro power plants, can be eligible under certain conditions. All producers of eligible renewable power receive one certificate for each MWh of electricity. These certificates can then be traded, with a guaranteed minimum price paid by the Swedish Energy Agency (SEA). This minimum price will drop to zero over the next 5 years. Thus, a producer of eligible electricity from RES can receive an income for sold certificates plus the wholesale price for the electricity produced. The certificate market is also open for other actors beyond producers and consumers, for example brokers and other intermediaries.

\subsection{Evaluation of the performance of the obligation scheme}

In the government bill on the obligation system (Swedish Government, 2002) it was proposed that the future quota levels should be reviewed every second year, starting in 2004. The system's function, effects, and the possibilities for increasing the level of ambition were to be assessed.

In the bill proposing the inclusion of peat (Swedish Government, 2003), it was further proposed that the first review of the policy should also include an assessment of the role of peat in the system and the exemption of the electricity intensive industry from the quota obligation. Conse-

23 For a general overview of RE policy in Sweden see Nilsson et al, 2004.

24 Production subsidies for land-based wind power will be phased out over 5-6 years. Targeted support for technology development and market introduction of off-shore wind parks and wind power in the mountainous regions has been introduced and some sort of targeted support for solar cells has been also been proposed. 
quently, SEA was commissioned by the Government in December 2003 to review the Swedish obligation system. The assessment was to be presented in two stages (1 of May 2004 and 1 of Nov. 2004). The first stage addressed peat, electricity intensive industry and the design of the quotas (SEA, 2004a). The second stage included the system's appropriateness to fulfil the goals of the renewable energy policy, future quota levels, the consumer's perspective, wind power, and statistics on production capacity (SEA, 2004b). The present assessment is largely based on these two evaluation reports complemented with other written sources and personal communications.

\subsubsection{Effectiveness}

During the first year, i.e., 8 months, of operation (2003, May-December) the electricity consumption that was subject to the quota obligation amounted to $61.1 \mathrm{TWh}$, which corresponds to 4.52 million certificates (7.4\%). On 1 April 2004, 3.49 million certificates were redeemed and 1.03 million certificates were not submitted. Thus, $77.1 \%$ of the quota was fulfilled and $22.9 \%$ was paid through penalties (SEA, 2004b). It should be noted that about 2 million certificates from 2003 were banked (SEA, 2004a). Thus there would still be a surplus of one million certificates even if the quota had been fulfilled. Electricity suppliers and others have until March 31 each year to deliver the certificates for redemption by Svenska Kraftnät (the Swedish Independent System Operator) so it is too early to say what the result will be for 2004. The explanation for banking is that actors are speculating that prices will increase in the future, although a surplus is accumulating in the short term. More certificates than needed for the obligation (i.e. $8.1 \%$ ) were produced again in 2004. Assuming that no penalties are paid for 2004, there is still an accumulated surplus of about 5 million certificates $(5 \mathrm{TWh})$ by the start of 2005 . The obligation for 2005 is about 10 TWh (equivalent to what was produced 1May 2003 to 30 April 2004). Whether prices will remain above $200 \mathrm{SEK} / \mathrm{MWh}(22 € / \mathrm{MWh})$ until, for example, 2007, when the quota reaches about $14 \mathrm{TWh}(14.1 \%)$, remains to be seen.

As expected, few investments have been made in new production capacity so far, although it is not possible to make exact estimates. Most of the production capacity serving the obligation existed before the introduction of the system, and additional production has resulted mainly from fuel switches (in CHP) or production increases (e.g., letting more water through small turbines, or increasing production of electricity in CHP) in existing plants. The growth in wind power production and installed power, which increased by about 20\% per year 1998-2003, appears to be slowing down. The planning of, and project planning for, wind power has decreased considerably in 2003 and 2004 since risk has increased and compensation has decreased compared to the old system with investment and production subsidies. Production support for land based wind power is being phased out ( $2 € \mathrm{ct} / \mathrm{kWh}$ in 2003 to $0.2 € \mathrm{ct} / \mathrm{kWh}$ in 2008 and then zero). The production support for off-shore wind power is $1.8 € \mathrm{ct} / \mathrm{kWh}$ in 2005 and $1.3 € \mathrm{ct} / \mathrm{kWh}$ in 2009 .

Table 5.1 Number of plants approved for TRECs as of 1 May 2004

\begin{tabular}{|c|c|c|c|c|}
\hline & Approved plants & $\begin{array}{l}\text { Installed power } \\
\qquad[\mathrm{MW}]\end{array}$ & $\begin{array}{c}\text { RES electricity } \\
\text { production } \\
{[\mathrm{GWh} / \mathrm{yr}]^{\mathrm{a}}}\end{array}$ & Utilization time $^{\mathrm{b}}$ \\
\hline Hydro & 1028 & 496 & 1754 & 3535 \\
\hline Wind & 562 & 416 & 724 & 1740 \\
\hline Bio energy ${ }^{c}$ & 100 & 3192 & 7233 & 2266 \\
\hline Solar & 1 & 0.008 & 0.006 & 750 \\
\hline Total & 1692 & 4105 & 9712 & \\
\hline \multirow{2}{*}{\multicolumn{5}{|c|}{$\begin{array}{l}\text { a) Production based on certificates issued } 2003-05-01 \text { to } 2004-04-30 \text {. For comparison, the obligation for } 2004 \\
\text { (2004-01-01 to 2004-12-31) is likely to be slightly above } 8 \mathrm{TWh} \text {. } \\
\text { b) Utilisation time is equivalent full load utilisation. }\end{array}$}} \\
\hline & & & & \\
\hline \multicolumn{5}{|c|}{$\begin{array}{l}\text { c) In another part of the same source (SEA, 2004b) it is reported that biomass CHP in district heating produced } \\
2.98 \mathrm{TWh} \text { and in industry } 4.47 \mathrm{TWh} \text {, in total } 7.45 \mathrm{TWh} \text { in the first } 12 \text { months. }\end{array}$} \\
\hline
\end{tabular}


Based on a commissioned study, SEA makes a rough guesstimate that the planned production increases in small-scale hydro power is $200-300 \mathrm{GWh}$, large hydro $200-300 \mathrm{GWh}^{25}$, district heating CHP 2-3 TWh and industrial CHP 1-2 $\mathrm{TWh}^{26}$. If these plans are realised, a surplus of certificates will continue to be generated also in 2007 and 2008. In the longer term, the potentials are estimated at $1 \mathrm{TWh}$ in small-scale hydro, 2-3 TWh in large hydro, 30-40 TWh in district heating CHP, and $5 \mathrm{TWh}$ in industrial CHP. Long-term potentials for wind, including offshore and alpine regions, are on the order of tens of TWh.

\subsubsection{Market efficiency}

The quota obligation is placed on consumers but, in practice, the obligation is handled by the electricity suppliers and the cost is passed on to consumers through a separate surcharge on the electricity bill. The electricity supplier is required to handle the obligation unless you are a large electricity user or have opted to register (against a small fee) in order to handle the obligation yourself ( 55 private consumers were registered in 2003). Since it does generally not make sense for private consumers to handle their own obligation, SEA has proposed a change in the legislation to put the obligation for private consumers on the electricity supplier. It has also proposed that the TREC price should be included in the electricity price, which is what suppliers compete on, and not put as a separate item on the electricity bill. In either case, the cost seems relatively easy to pass on, at least to small electricity consumers ${ }^{27}$.

Trade in certificates is bilateral or through brokers, but all transactions are registered at Svenska Kraftnät. It is also possible to trade at Nord Pool since March 2004 (but only 17 users were registered in January 2005). Trade in TREC forwards at Nord Pool will be possible as of April, 2005 onwards. In addition to producers with TRECs to sell and buyers with an obligation, there are also traders and brokers. The possibility of banking (and borrowing during the first three months each year) introduces some flexibility to the otherwise relatively inelastic demand and supply. Forward trading is possible through some power brokers. Svensk Kraftmäkling, a major power broker, offers delivery of certificates in 2007 and later (SEA, 2004b).

On 24 March 2005, there were 15.7 million certificates registered at Svenska Kraftnät (including the 3.49 that were redeemed on 1 April 2004, a total of 19.2 million have been issued). Assuming that 8 million are needed for the 2004 obligation ( $8.1 \%$ of $100 \mathrm{TWh})$ this leaves about 4.5 million for 2005 and later. The main explanation for accumulation is that market actors speculate on higher prices in the future. In addition, SEA has noted that the penalty ceiling has initially provided incentive for sellers to stay in the region of the penalty. As a remedy to the potential market power issue, SEA has proposed that the possibility to borrow should be extended. However, representatives from SEA, Vattenfall and Svensk Kraftmäkling have indicated that the development of TREC market prices show that market power is not an issue.

A detail noted by some stakeholders is that the price of a TREC is not reported until the transfer of the TREC to the new owner takes place. For example, there are probably bilateral agreements for future delivery but the market does not see the price until the delivery takes place and is reported to Svenska Kraftnät. Hence, price transparency is not perfect. A further development of the market, e.g., developing financial trade at Nord Pool or expanding it to more countries, could help improve market efficiency.

25 For example, Vattenfall (Sweden's largest utility and hydro power producer) estimates that some 100-150 GWh will be added to their total hydro power production of $33 \mathrm{TWh}$ as a result of their current renovation program.

26 For example, the pulp producing company Sodra is planning to increase production by at least 3-400 GWh through investments in steam turbines (two back pressure and one condensing) to be completed by 2006/7 at their three pulp mills.

27 For a small consumer, say $3000 \mathrm{kWh}$ per year, switching to a supplier with a $10 \%$ lower electricity price translates into $90 \mathrm{SEK}(10 €)$ at a price of $0.30 \mathrm{SEK} / \mathrm{kWh}(3.3 €$ cent $/ \mathrm{kWh})$. Switching to a supplier with a $10 \%$ lower certificate surcharge could save 7.5 SEK $(0.83 €)$. 


\subsubsection{Certainty for the renewable energy industry}

A major uncertainty of the electricity certificate system is caused by its relatively short time frame. The system is decided to run until 2010 and after that it is unclear what will happen. From a political point of view, and compared to earlier subsidy systems, the system has a rather long time frame. However, considering the long time horizon for investments in new electricity production from renewable energy (approx. 15-25 years) the timeframe is still short. A further source of uncertainty is political modifications of the system that are, or can be, introduced gradually. One example of a modification that has been carried through is the inclusion of peat in the system in April 2004. Changes that are being discussed at present include the size of future quota obligations and the future extension of the system to include Norway (in 2007 at the earliest).

An important market uncertainty of the system has to do with fluctuations in the price of electricity certificates. Because of the small size of the market, large investments in renewable electricity can have significant impacts on the price. This adds to the difficulties of calculating future returns on investments. Risks coming from price fluctuations can in theory be handled by derivatives trade, e.g., futures and forwards, and through long-term bilateral contracts.

The short time frame of the system is perceived by market actors as the most serious problem. It increases the risks of investments and makes it more difficult to find finance. The effects of this uncertainty, however, affect different technologies and actors differently. Small investments to increase production in existing capacity (in bio-fuelled CHP plants and small hydro plants) are favoured by the obligation system because these involve both lower risks and lower costs. Investment in new capacity is, on the other hand, affected much more significantly. Banks have been restrictive in offering loans to investments in new renewable energy projects under the obligation system and so far there have been few investments in genuinely new production capacity. However, it is too early to draw definite conclusions about the conditions for new investments, considering that the system has been running for less than two years. When the possibilities to increase capacity in existing plants have been used up there will be an increased pressure to invest in new production capacity and the significance of investment risks will become more pronounced. New biomass plants are comparatively less affected by the uncertainties, since the investment cost only constitutes a small share of the total cost of CHP production. The conditions for wind power have been widely discussed and analysed in Sweden. Small actors are generally more affected than large ones, since they tend to be more dependent on external project finance and since their liquidity is generally lower. Large actors are expected to invest in future expansion of wind power, mainly through investments in off-shore wind parks.

The significance of price fluctuations of electricity certificates is perceived differently by different actors. Interviews with biomass and hydro power producers show that they do not see uncertainties connected with price fluctuations as a big problem compared to the uncertainties created by the short time frame of the system. The risk of price fluctuations is instead seen as one element in the electricity price and does not have a decisive effect on investment decisions.

Wind power developers, on the other hand, are of the opinion that the previous system with a fixed environmental bonus gave a stronger incentive for investments since it was stable, while certificates vary in price. The more negative view of wind power developers should be seen in light of their general situation - small actors, capital intensive investment, limited access to financing and the fact that the previous system was more generous.

SEA strongly recommends that the time frame of the electricity certificate system be extended so that it is long term enough to create a stable environment for new investment decisions and facilitate long term contracts. This would reduce the risks of new investments and make it easier to find financing. The SEA also discusses the need for more ambitious quota levels, which would generate a higher return on investment. The future of the obligation/TREC system after 2010 is at the moment being considered by the government and a parliament decision is ex- 
pected in 2005 . The prolongation of the system does not seem to be a controversial political issue.

It may be noted that it is paradoxical that uncertainty is falling out as the most severe weakness of the system since one of the key motivations for introducing the system was the great uncertainty involved in earlier subsidy schemes. The obligation/TREC system was proposed as a way of creating more stable conditions.

\subsubsection{Cost effectiveness}

The cost effectiveness of the obligation/TREC system depends on the cost at which this system fulfils its purpose of increasing the electricity production from RES. In 2003, the obligation/TREC system cost electricity consumers with a quota obligation 1305 million SEK (145 million $€$ ). During the first 12 months of operation (1 May 2003 to 30 April 2004) nearly $10 \mathrm{TWh}$ of electricity eligible for certificates were produced (N.B. the quota obligation is per calendar year and the period chosen here is only for illustration). This is $3.5 \mathrm{TWh}$ more than what was estimated in the Government Bill (Swedish Government, 2002) to be the existing annual production capacity eligible for certificates, and 3.3 TWh more than would be required based on the consumption of electricity users with an obligation in the same period. Consequently, it seems that the pre-existing production capacity was underestimated. With a shortterm perspective, it can thus be argued that consumers have paid dearly for RES electricity from pre-existing production capacity.

It is not possible to say exactly how much genuinely new capacity the obligation system has resulted in so far. Plants that were taken into operation after 1 May 2003 include 7 hydro, 39 wind, and 1 biomass plant, in total 47 plants with an estimated annual production of $104 \mathrm{GWh}$. However, it is difficult to distinguish the influence of the obligation from previous and other policy instruments and decision criteria. Since 2003, projects which concern renewable energy have also been able to receive funding from the climate investment programmes (KLIMP). The objective of KLIMP is to fund investments, which result in reduced emissions of greenhouse gases. During 2003, projects primarily in the energy and transportation sectors were granted 300 MSEK (33 MEUR), parts of which were invested in electricity production from RES. In addition to this, there is the production subsidy for wind power, although it will be phased out for land-based wind power by 2009. It is clear, however, that the obligation system has initiated ongoing and future investments, notably in biomass-based CHP.

The present obligation system has been criticized by some for being too generous with respect to existing production capacity. Critics argue that these plants have been built without expectation of this extra income, which makes them free-riders of a system intended to increase the amount of electricity production from RES. Most of these plants are based on commercial and mature technologies, such as biomass-based CHP. On the other hand, others argue that it would be unfair to exclude existing plants completely from the certificate system. Such a decision could have the unfortunate effect of biomass-fired CHP plants being strategically converted to firing fossil fuels for a period of time, after which switching back to firing biomass and thus being eligible for certificates again. The inclusion of existing plants is also motivated by the ambition to get market liquidity.

Another aspect of cost efficiency is how the revenues from certificates, including penalties, are distributed. In 2003, RES-E producers received $49 \%$ of the total revenue of 1305 million SEK (145 million $€$ ). The State received $34 \%$ of the revenues from collection of value added tax (VAT) and the penalty fee. The penalty fee was paid by those $23 \%$ of customers who did not comply with their certificate obligation. Finally, electricity suppliers kept $17 \%$ of the revenues, partly as profit and partly in order to compensate for transaction costs. The transaction costs for the electricity suppliers primarily refer to administrative costs of handling the certificates on behalf of customers. Transaction costs are probably even greater for the producers, many of which 
are very small companies for whom administrating the certificate system will be burdensome. As of today, with less than half of the money paid for certificates reaching the RES-E producers, there is a risk of the system losing legitimacy, especially with consumers.

It should be mentioned that there is a discussion concerning mechanisms of how the penalty can be re-circulated from the government and back to the obligation system (for example, back to the electricity suppliers, back to producers, into a fund for supporting RES electricity, or into a fund which finances the guaranteed price). It is, however, likely that the State's revenues from the penalty fee will decrease during 2005 since the ceiling for the penalty will be removed. As a consequence electricity suppliers and users will probably be more inclined to fulfil the quota. Recirculation would also increase the administrative burden and SEA proposes that borrowing (i.e., a possibility to retroactively meet the quota) should be introduced to reduce the problem of penalties draining the obligation system (and increase demand elasticity).

\subsubsection{Stakeholder support for the system}

In general the obligation system has been accepted and is supported by the main actors in the market. It is seen by many observers as a positive step forward compared to earlier subsidy systems, which were criticised for failing to give long term stability to the market. However, apart from interviews with companies in the wind power sector, there has been no systematic study of the attitudes of different groups towards the obligation system. Though the system is generally accepted, different actors criticise it from their perspective and try to change it to their advantage. Some key issues in this regard are discussed in this section.

Wind power. The wind power interests, mainly small scale producers, were initially very sceptical of the policy. They feared, and have basically been proven right, that the system would make it difficult to find financing for new investments and that wind power would not be able to compete with bio-fuelled CHP plants. Once the system was introduced the major wind power actors have, however, accepted it and instead have focused on trying to secure conditions for wind power that are as favourable as possible. At the moment, wind power receives additional subsidies which will gradually be phased out. A main concern of the wind power actors is the need for measures to reduce investment risks, such as extending the time frame of the system in order to guarantee long-term returns and introducing a quota level that is high enough to secure a sufficient level of returns.

Peat. Peat was not originally included in the system. However, partly because of pressures from interest groups, a decision was made to include peat from April 2004. Such an inclusion creates some problems. First, the fact that the system is no longer exclusively for renewable energy can create problems of legitimacy. Second, the inclusion of peat may become problematic in a future internationalisation of the system since other countries classify peat as a fossil fuel. The future of peat in the system is unclear.

Electricity intensive industry. Companies in the electricity intensive industry are exempt from the system and do not have any quota obligation. The reason for this is that it was judged that an inclusion in the system would affect their international competitiveness. Without an exemption it would probably have been difficult to get acceptance for the obligation system. Some problems, however, exist concerning the definition of what is an energy intensive industry. Today the definition is based on the type of industrial sub-sector that each company officially belongs to (SNI codes), not on the actual electricity intensity of the company. The result is that some companies with comparatively low electricity intensity are exempted while others with high electricity intensity are included. Changes have been suggested to make the system more accurate and fair in this respect. Some observers have argued that all electricity intensive industry should be included in order to make the system more fair and effective, e.g. it would probably 
increase long-term contracting. Such a move would, however, be politically difficult and seems unlikely at the moment.

Household consumers. The reaction of household consumers to the policy has been limited, which might be explained by the fact that the obligation imposes a small cost on households. Awareness and knowledge of the system among the public is generally low and the surcharge is perceived as a fixed fee or a tax. A discussion exists about the risks that the system will loose legitimacy because of the fact that less than half of the revenues from the system go to renewable energy producers.

\subsubsection{Equity}

Below, the main issues related to equity are discussed. Most of them were known before the obligation system was launched and have been regarded by decision makers as acceptable consequences of the system. Some of the issues have already been covered in other sections and will only briefly be recapitulated here.

Pulp and paper industry. As mentioned in the previous section, the electricity intensive industry is exempt from the system, which can be regarded as an equity problem. However, the argument of international competitiveness is so strong that it is not politically possible to change this situation. A more pertinent equity issue is the fact that the pulp and paper industry is favoured twice by the system. On the one hand, these companies have no obligations since they belong to the electricity intensive industry. On the other hand, they receive certificates since they often own CHP plants that are fuelled by biomass (e.g., lignin and bark) which is a byproduct. The pulp and paper industry produced about $4.5 \mathrm{TWh}$ of eligible RES-electricity in the first 12 months of the obligation system, worth about 900 million EK (100 million $€$ ). The pulp and paper industry, however, seriously considered that pulp-wood prices may increase as there is more competition for biomass.

Increased revenues to existing RES-E plants. Both existing and new capacity is eligible for certificates in the obligation system. This has in practice meant that many existing RES-E plants have increased their revenues considerably compared to the earlier situation (SEA, 2004a). Compensation to biomass and small scale hydropower has doubled, and together with generally high electricity prices their revenues have been exceptionally high. Overall compensation to wind power has slightly decreased compared to the previous system consisting of investment and production subsidies. It is not clear whether this should be considered an equity problem.

Differences for different technologies and actors. In Section 5.2.3, it was discussed that the present system increases the risks for investments in new RES-E capacity. It was, furthermore, argued that the system is less favourable for some types of RES-E plants than others, which could be seen as an equity problem. Likewise, the system is more suited for large actors than for small ones, which may also be regarded is an equity problem. However, the system is designed to be technology neutral and stimulate cost-effective production and is not favouring specific technologies or actors.

Extra revenues to the state. Finally, the obligation system has meant additional revenues to the Swedish state, which can be compared to the earlier system where the state paid subsidies to renewable energy. When electricity distributors manage the certificates for customers this is defined as a service and a VAT of $25 \%$ is imposed. Furthermore, the quota obligation fees (penalty for not having enough certificates) go directly to the public treasury (SEA, 2004b). In 2003 this meant that about one third, or 435 million SEK (48 million $€$ ), of the revenues from the obligation system went to the state. In the SEA evaluation it was suggested that there is a need to reform the system so that the revenues from the quota obligation fees instead are used to support 
the RES-E industry. However, the VAT on certificates is seen as logical since taxes on energy and electricity also have a VAT imposed on them.

\subsection{Other key issues}

In addition to the issues covered in the previous sections, the issue of double counting and the possible extension of the obligation system to include Norway must be mentioned. We also summarise other key issues, focusing on those that are not elaborated above, as they were reported in four short reports by academics that were commissioned by SEA. Finally, SEA's assessment of post 2010 quotas is briefly summarised.

\section{Double counting}

The interaction between the obligation/TREC system and other policy instruments, such as other subsidies for RES-E, has been the subject of some debate but the issue of double counting has not been prominent. We comment briefly here on the interaction with the Swedish NGO green labelling scheme and the EU emissions trading scheme (EU-ETS). There is no double counting with the voluntary Renewable Electricity Certificate System (RECS). TRECs that are sold abroad through RECS are removed from the Swedish market (with current prices there is no such trade). The Swedish obligation system does not allow imported TRECs. There is also no conflict with Environmental Product Declarations (EPD) which simply states the environmental impact of specified electricity production (nuclear, fossil, or RES). There is a potential double counting problem with Guarantees of Origin $(\mathrm{GoO})$ since this system is separate from the TREC system in Sweden ${ }^{28}$.

The Swedish Society for Nature Conservation (SSNC) has operated a green labelling scheme (Good Environmental Choice, BMV) for many years. Starting in 1996 this system included also green electricity according to eligibility criteria set up by the SSNC, which differ from the obligation system criteria by focussing more on environmental impacts. However, in the overlapping areas there can be double counting (also with GoO). The sales of BMV-electricity reached its peak in 2001 at nearly $16 \mathrm{TWh}$ but fell to $8 \mathrm{TWh}$ in 2003. The reasons for this include the obligation system introduction, increased BMV prices, and generally increased electricity prices. Electricity from RES-E can be labelled BMV and get TRECs for meeting the obligation, but double counting with BMV has not been an issue of concern for SEA or SSNC. However, SSNC has been a strong critic of the obligation system.

It may be debated whether or not it is a problem if an additional BMV premium is added to electricity which is eligible under the quota system.

The principal interaction between the obligation/TREC system and EU-ETS is that electricity from RES will reduce marginal, often coal-based, power production and thus reduce the price of carbon emission permits. Vice versa, high prices for emission permits will increase the price of electricity which may put downward pressure on the price of TRECs. The Norwegian Water Resources and Energy Directorate (NVE) simply states that the objectives of the two schemes are different - reducing GHG emissions versus supply security, environment, and innovation.

\section{Internationalisation}

The issue of internationalising the obligation/TREC system was discussed and proposed in a government report (Swedish Government, 2002) that preceded the creation of the obligation/TREC system (prop. 2002/01:40). In December 2004, meanwhile, SEA reported to the government on the consequences of an extended electricity certificates market (SEA, 2004c).

28 For a discussion on potential doubling counting problems between GoSs and TRECs see Uyterlinde et al, September 2004 
Norway's NVE issued a report (No. 11, 2004) on an obligation/TREC system in September 2004 and the Department of Oil and Energy presented a legislative proposal on 24 November for public hearing, asking comments from stakeholders by 1 February 2005. NVE's main conclusion is that an obligation/TREC system can work well for promoting the production of electricity from RES. NVE states that this requires that the system is technology neutral, has a sufficiently high quota obligation, is long term, and can be well coordinated with the Swedish system. A Norwegian market, it is thought, would be too small. Enacting the legislation appears to be contingent on the integration with the Swedish obligation/TREC system.

One of the main arguments for extending the system to include more countries, i.e., Norway in this case, is that the targets can be met at lower cost. In addition, there are market advantages (higher liquidity, less price fluctuations, and lower political risk). However, an extended market shifts the focus from how much RES-electricity should be produced in Sweden, to how much RES-E Sweden is prepared to finance, irrespective of where the production capacity is located. The national legislation must be carefully harmonised. It is estimated that Norway would export about $5 \mathrm{TWh}$, in a hypothetical case where Norway and Sweden would assume targets of 10 and $21 \mathrm{TWh}$ for 2016, respectively. With more ambitious targets, 20 and $21 \mathrm{TWh}$, respectively, Sweden would export about 4 TWh to Norway. The flows arise due to differences in marginal costs and potentials for various RES-E (SEA, 2004c). Although extending the market to include Norway makes economic sense (at least in theory), getting public acceptance and political support may be a challenge. Should Swedish consumers subsidise Norwegian producers, and vice versa?

\section{Other details}

As an input to the evaluation process (SEA, 2004b), SEA commissioned a number of researchers to study the extent to which the obligation system was conducive to the overall goal of increasing electricity production from RES (Åstrand, 2004, Kåberger et al.,2004, Söderholm, 2004, Bergek, 2004). We consider the discussion and critique put forth in these reports as reflecting much of the academic debate. The main strands of critique are in three different areas: economics, technology development, and non-financial barriers to RES-electricity.

On the economics, one line of critique is that carbon taxes would be economically more efficient for reducing carbon emissions. Although the stated goal of the obligation system is to increase electricity from RES and not to decrease carbon emissions, the climate issue is an underlying motivation, together with supply security. In this sense, the obligation/TREC system is a second best solution. The potential problem of volatile prices, due to low liquidity and poor elasticity of demand and supply, is also raised. A problem that was perhaps not foreseen is that the system is relatively expensive for consumers - only about half of the surcharge reaches the producer.

In addition, the price mechanism, where price is set on the cost of marginal production results in windfall profits for some producers. The exemption of the pulp and paper industry from the obligation is also subject to critique since many plants can get TRECs for their internal biomass based generation, but those same companies are not required to meet the obligation.

In the area of technology development, most observers conclude that the obligation system, the purpose of which is to stimulate new but least cost RES electricity production, is not well suited for stimulating technology development. The current understanding of innovation systems, the need for nursing markets, investments in learning by doing, and for managing the introduction of new technologies, leads to the conclusion that more is needed than a (risky) production subsidy as offered by the obligation/TREC system.

There may also be numerous barriers to investments in electricity from RES-E that are not purely financial in nature. These barriers may be electricity market regulations (under what conditions you can get access to the grid), planning and permitting procedures, and regulation in 
other policy domains (for example, forestry and agricultural policy are relevant to biomass). For example, in the case of wind power there are considerable differences in planning and permitting between different municipalities ${ }^{29}$. Hence, it should be noted that an obligation system by itself does not solve the entire problem of increasing electricity from RES-E.

A strong recommendation in the evaluations by SEA is that the system should be made more permanent. SEA concludes that the highest reasonable potential for 2015 is $26 \mathrm{TWh}$, an increase by $19 \mathrm{TWh}$ from 2002. According to a scenario where this is implemented by 2015 and the quota held constant until 2025, this would put great demands on permitting for large-scale expansion of wind power, and involve high costs for consumers. Nevertheless, SEA concludes that a target of $15 \mathrm{TWh}$ of new production (21 TWh in total) is reasonable for 2012, but emphasises that quotas, even if constant, must be set for many years thereafter. A proposal concerning new quotas and integration with Norway is expected by late 2005 or early 2006.

\subsection{Conclusions and lessons learnt}

As stated in the introduction, the overall objective of the certificate scheme is to increase the production of electricity from RES by 10 TWh from 2002 to 2010 (for the time being) and to induce competition between different RES. Apart from that a number of secondary objectives have also been advanced. These objectives include that the obligation system should (e.g., SEA, 2004b and SOU 2001:77):

- create a long-term stable playing field,

- be possible to internationalise,

- avoid distorting the function of the electricity market,

- create reasonable conditions for existing plants,

- stimulate technology development and cost efficiency,

- promote new investments.

The evaluation of the obligation/TREC system by SEA looks at how these stated goals are being met (SEA, 2004b). The results are briefly summarised here. One of the main weaknesses of the system today is that it has not created long-term stability in the eyes of market actors. There is a risk that the $10 \mathrm{TWh}$ target may not be reached unless the system is made more permanent, with quotas and rules post-2010. Internationalisation is possible, even desirable, but requires that several conditions be met, and many details ironed out. The system is likely to have a small effect on the electricity price as electricity from RES will replace marginal power production on the Nordic market.

The resulting support for existing plants has nevertheless been very generous except in the case of wind power. It is also quite clear that the system is not conducive to the development of new (but expensive) technologies such as off-shore wind power or solar PV. It is cost-effective in the (narrow) sense that low-cost electricity from RES (from small hydro and biomass, and nearly all pre-existing plants), is produced. However, it has been costly for consumers and many, or most, TREC producers are over-compensated. There have been few new investments so far, but nothing else could be expected in the short time since the system started, and the situation is likely to change as the quota increases. Finally, it is stated that the practical experiences are good so far, although the system was introduced under a tough time-plan and this created some initial mishaps and delays concerning registrations, reporting, and the like.

Apart from the above conclusions, there are some key observations and dilemmas regarding the Swedish obligation system which we would like to advance:

29 Khan J., 2004. Local Politics of Renewable Energy, PhD-thesis, Department of Environmental and Energy Systems Studies, Lund University. 
- Longer quotas and more permanence, together with internationalisation, may help in putting the system at increasing length from short term political decisions, but the problem of political risk will always be there (this is the case for any support scheme). As the system is more and more institutionalised, this risk should decrease.

- Since, in theory, the price of TRECs will be determined by the marginal cost of production, the system will always provide generous compensation to some low-cost producers - and thus be costly to consumers. A general policy instrument - such as the obligation system - is blunt compared to targeted instruments. A proposed remedy, such as putting a 10 year time limit for how long a plant can be eligible, is also problematic. This may induce fuel-switches back to fossil fuel and then biomass again, or reconstruction of small hydro plants followed by a renewed application for TRECs.

- The system claims to be technology neutral and in a sense this is true since all technologies receive the same support under competition. However, introducing this type of competition between RES-E is nevertheless a very strategic choice leading to the promotion of certain technologies: those which can compete and which fit the system. Other types of RES, which might have high long term potentials, face the risk of being ignored. Thus, the system is apparently in conflict with the need to nurse new technologies. Targeted support could be seen as distorting the system. However, we do not see this as a big problem as long as the support is small enough not to upset other RES producers too much. Another point is that the system promotes technologies for RES electricity production and it is therefore not neutral vis-à-vis heat production or transportation fuels.

- An interesting observation is, in simple terms, that Sweden has moved from a situation with considerable energy RD\&D efforts with very little market activities to the opposite. Energy RD\&D was cut by about $40 \%$ in 2004 and strong market demand is now created through the obligation system. In neither of these situations has there been any serious efforts to promote the phase in between, i.e., the introduction and diffusion of immature technologies through nursing markets.

- The obligation/TREC system is best suited for larger actors, who have the financial strength to handle higher investment risks and who can get better loan conditions from banks. The system is less sensitive to the needs of small independent power producers. On the other hand, small independent power producers are not expected to be able to deliver the volumes of RES-E targeted in the obligation. 


\section{Experience in the U.S.A}

\subsection{Introduction}

Perhaps the most extensive and diverse base of experience with obligation systems exists in the United States, where 18 states and Washington, DC have created obligation policies, termed renewables portfolio standards (RPS) in the USA. These states were identified in Chapter 3. Electricity suppliers in these states collectively serve $\sim 40 \%$ of total US electricity consumption. These policies apply in markets that are open to retail electricity competition, and in states where traditional, still-regulated monopoly electricity markets prevail.

Importantly, while the number of states that have created RPS policies is large, experience with these policies remains somewhat limited; few of the states have more than five years of experience with their RPS programs, and some of the policies have been established but have yet to take effect. Nonetheless, the diverse design of RPS programs among states allows some robust conclusions to be reached even at this early stage.

An important observation is that there is clearly no single way to design an RPS, and each of the 18 states has crafted their RPS policies differently, sometimes radically so. (Some of these differences, focusing on just 4 states, were noted earlier in Chapter 3). The percentage purchase obligation, for example, increases to just $1.1 \%$ in Arizona, but to $20 \%$ in California. While wind, solar, and geothermal energy are eligible under most of the RPS policies, criteria for the eligibility of biomass and hydropower varies considerably across states. Some states even allow non-traditional sources to qualify, including energy efficiency and gas-fired fuel cells. Differences also exist across states with respect to the duration of the policies, whether additional technology bands exist, how out-of-state RE generators are handled, whether existing RE plants are eligible, what kinds of enforcement is possible, and what level of compliance flexibility is allowed. Importantly, most of the states have developed or are developing TREC markets to ease compliance burdens. This is not universally the case, however, with some states requiring bundled renewable electricity purchases to meet the obligations. See Wiser et al. (2004) for a more detailed discussion of the specific design of these different RPS policies.

\subsection{Evaluation of the performance of the obligation scheme}

\subsubsection{Effectiveness}

State RPS policies have been estimated to have helped motivate demand for 2,335 MW of new renewable energy capacity through 2003 (Petersik 2004). The vast majority of this capacity 2,183 MW - is wind power, with the most substantial demand for renewable resources coming from Texas (1,140 MW), Minnesota (476 MW), Iowa (237 MW), and California (175 MW). In fact, of the 4,300 MW of wind power installed in the US from 2001 through 2004, approximately half appears to have been motivated in part by RPS requirements.

Though state RPS policies helped support these additions, it should be noted that federal tax policy also plays a major role. Federal production and investment tax credits, along with accelerated depreciation schedules, substantially reduce the cost of renewable energy supply used to comply with RPS policies. As such, success with RPS policies in some US states has been bolstered by federal tax policy. 
In the majority of states, electricity suppliers have so far complied with the policies through renewable energy purchases, and not through payment of alternative compliance payments or penalties. There are exceptions, however. In Nevada, for example, the utilities signed a number of contracts with renewable developers who have failed to bring their projects on-line on schedule. The result has been substantial under-compliance, and the utility regulator has so far opted not to penalize the utilities for this lack of compliance. In Arizona, the RPS has also only been partially achieved. In most other states (e,g., Texas, New Jersey, Wisconsin, Minnesota), compliance through renewable energy purchases has been the dominant result so far. In Connecticut and Massachusetts, however, there is concern that new renewable energy supply is not being added rapidly enough to track RPS-driven demand; as a result, in Massachusetts at least alternative compliance payments may are increasingly being used. Whether such concerns develop in other markets remains to be seen.

Though these policies are still young, on a going-forward basis, state RPS programs are expected to grow in significance. Assuming that these policies are complied with in full (admittedly, an aggressive assumption), Figure 6.1 shows the amount of new renewable energy capacity that would be required by $2017 .^{30}$ Total demand would exceed 25,000 MW, with the largest markets in California, New York, Pennsylvania, Minnesota, Texas, Nevada, and Massachusetts.

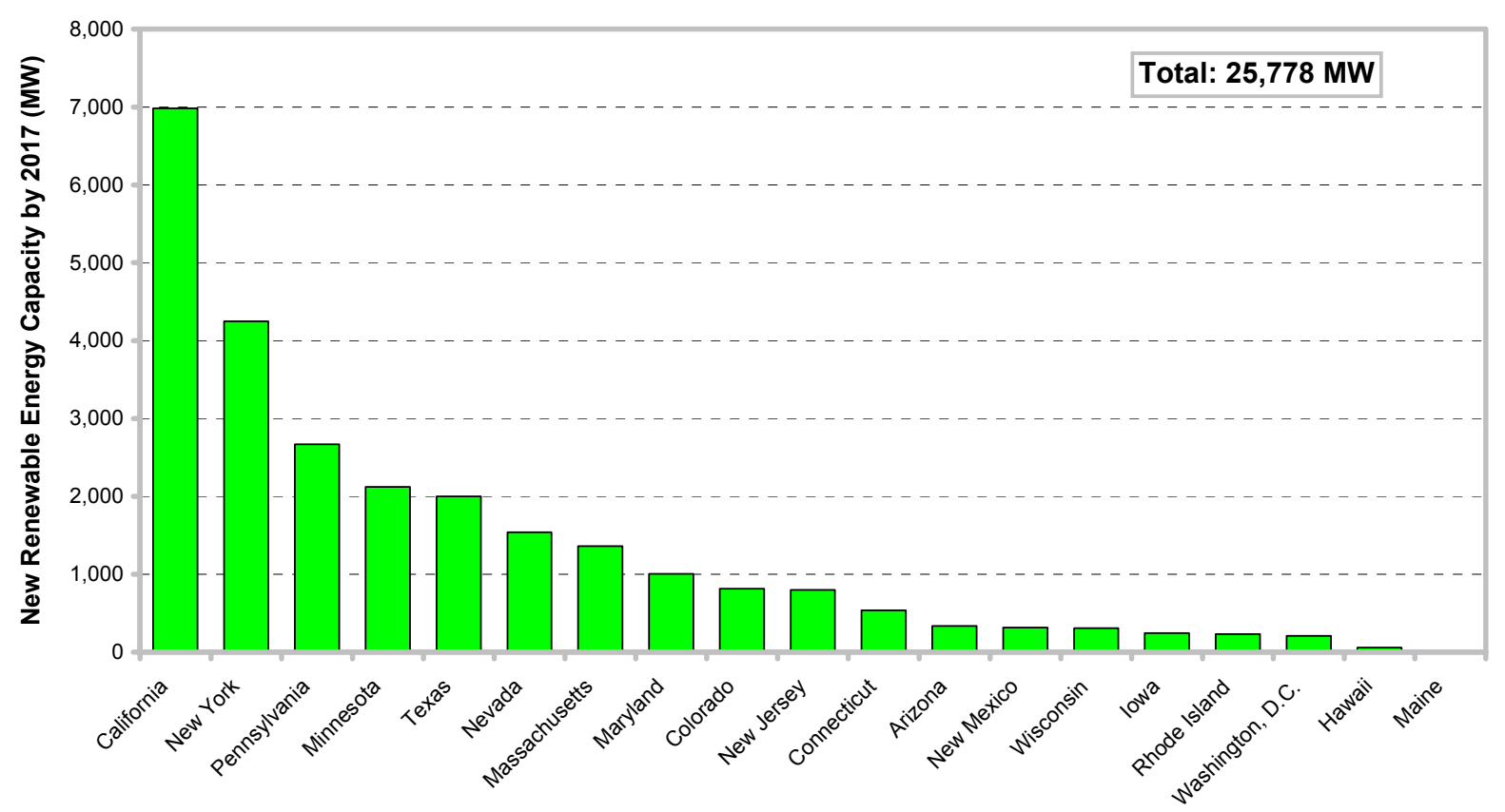

Figure 6.1 The projected impact of state RPS policies by 2017

Source: Union of Concerned Scientists and Lawrence Berkeley National Laboratory

Due to the economic competitiveness of wind (due, in part, to federal tax incentives), wind power is expected to play a sizable role in meeting these requirements, but demand for biomass and geothermal resources may also be significant. Solar photovoltaic energy, though not a competitive resource compared to wind power, could contribute approximately 1,000 MW by 2020, due to solar set-asides within the RPS policies of 6 states and Washington, D.C. While these projected additions are substantial compared to historic rates of growth, the aggregate amount of renewable generation required under these policies by 2017 equates to just $3 \%$ of total 2002 electric sales in the US, and to $7.2 \%$ of 2002 load in those states with RPS requirements.

30 Selection of 2017 is somewhat arbitrary, as several of the RPS policies continue to increase after this date. Nonetheless, by 2017, most of the state RPS policies are expected to be in full-swing and many will have reached their terminal percentage requirement. 
In addition, it deserves note that much of the impact to date has been restricted to just a few states, and there are a number of instances in which state RPS policies are not yet having their desired effect. The reasons for the poor performance in a number of US states are detailed below.

\subsubsection{Market efficiency}

The market efficiency of RPS policies in the US varies substantially among states, dependent in large part on the availability of longer term contracts for renewable generators, which in turn relates to the perceived stability of the underlying political commitment to renewable energy. In fact, the single most enduring lesson from US experience is not a new one: renewable energy projects generally require long term sales contracts to obtain financing, and to deliver energy at reasonable cost.

Reflecting the key design differences among state RPS policies, as well variations in the supplydemand conditions and renewable resource availability across states, Figure 6.2 presents recent trading prices (updated through November 2004) for 2004 vintage TRECs. It should be noted that this figure is not comprehensive: TREC trading is not yet authorized in some states. Nonetheless, the figure clearly indicates that short-term TREC prices vary substantially across regions and resource types.

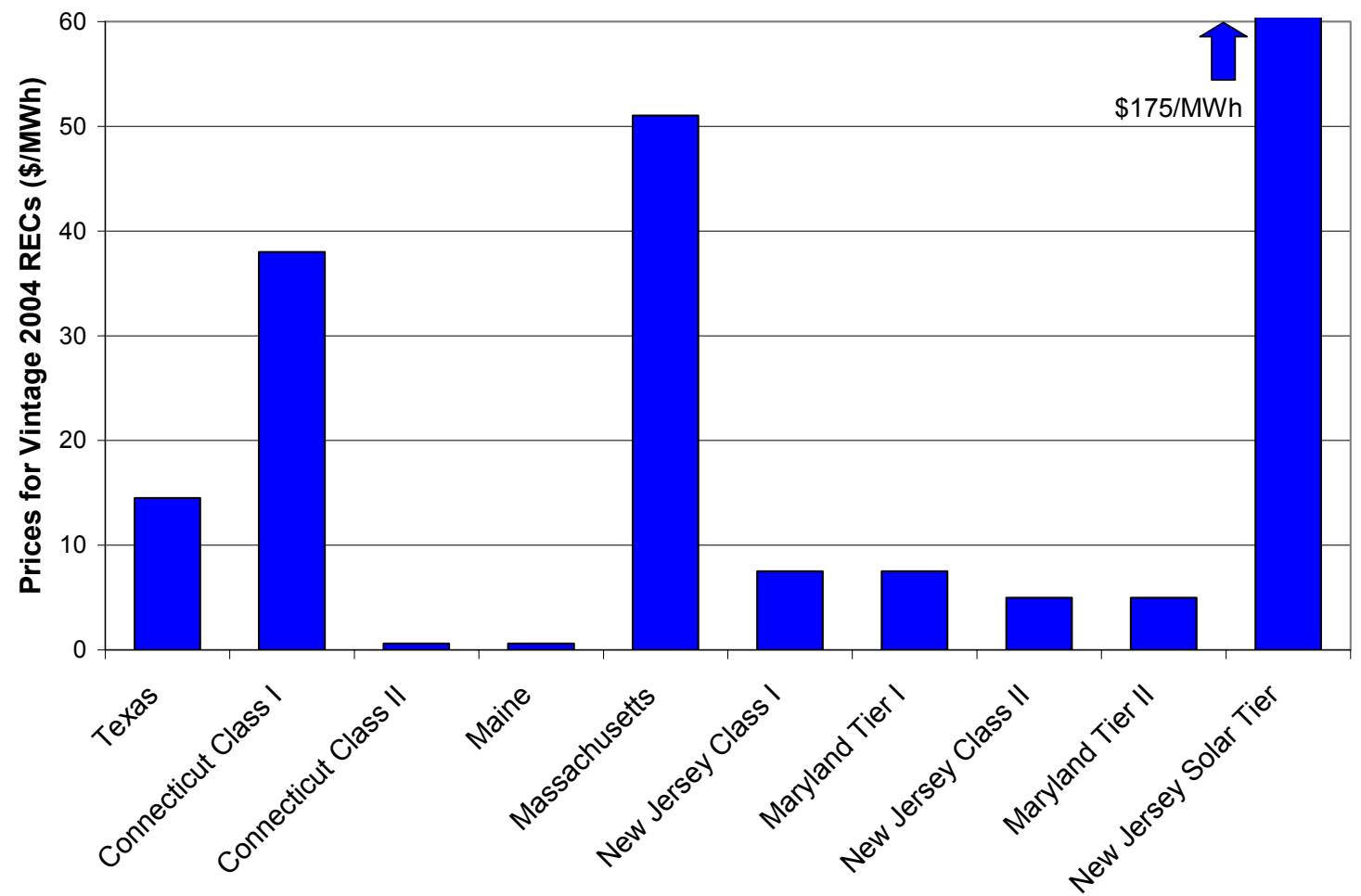

Figure 6.2 Recent prices for vintage 2004 TRECs among states Source: Evolution Markets

Some of this variation can be explained by RPS design: the Maine and Connecticut Class II requirements can be met entirely with existing renewable generation, suppressing TREC prices, for example, while New Jersey solar TRECs are costly due to the underlying cost of solar electricity. In other cases, the high price of TRECs is caused by RPS-driven demand that temporarily exceeds available renewables supply (Massachusetts, and Connecticut Class I). Though such a price rise might be considered an efficient reaction to a supply-demand imbalance, the more fundamental problem is that even at these high prices, renewable generation supply is not rapidly expanding. The reason: a lack of long-term contracting. 
In markets where long-term contracts are available (often TRECs bundled with electricity), renewable electricity is typically procured competitively, and at reasonably low prices. This has been the norm in Texas, Minnesota, California, Iowa, and Wisconsin, and in these cases renewable energy is being sold at prices that reflect active competition among developers. In fact, with available federal tax incentives, wind power contracts can be as low as $\$ 25-35 / \mathrm{MWh}$, leading to consumer electricity price savings from RPS policies in at least some instances, as opposed to electricity price increases. The RPS is working, and working efficiently in these markets.

Though some may argue that such long-term contracts impede transparency and liquidity in the short-term TREC market, such arguments are without merit. Long-term contracts are necessary for renewable developers, and developers are more than willing to enter into active competition for those contracts. It is far more important that developers compete for long-term contracts that facilitate financing and low-cost RPS compliance than for short-term TRECs trade to thrive.

This is shown in other markets, where long-term contracts have been scarce. Especially in restructured electricity markets, where load obligations are uncertain and purchasers often have poor credit, retail suppliers have typically been reluctant or unable to enter into longer-term contractual arrangements for renewable electricity or unbundled TRECs. This has been the case in Massachusetts and Connecticut, but the problem may spread to other markets as RPS targets become binding. In these instances, the RPS is driven by short-term TREC trade, often causing TREC prices to rise considerably, and it remains to be seen whether this circumstance can adequately support new project development over time and whether the resulting aggregate cost of the RPS will be minimized relative to other policy efforts. ${ }^{31}$ Evidence to date suggests that RPS policies based on such short-term trade will be costly compared to other, more stable forms of policy support.

\subsubsection{Certainty for the renewable energy industry}

Contributing to the lack of long-term contracts in some states is a level of uncertainty about the underlying purchase mandate: will policymakers choose to maintain the standard, increase the standard, or even eliminate the standard over time, and will policymakers strongly enforce the RPS? Without this certainty, renewable generators may not be able to obtain the long-term sales contracts that are necessary to access low-cost finance. At the same time, obligated purchasers may not be able to plan for long-term, least cost compliance with a policy whose duration itself is unclear.

The large number of states developing RPS policies in the US mitigates these concerns somewhat: the gain or loss of any individual policy may not be catastrophic. Nonetheless, uncertainty over the future of the RPS is of concern in some markets. In Arizona, for example, the RPS was initially established with a 2003 cost-benefit evaluation, which would help determine the fate and design of the policy after just several years of policy experience. The duration of Maine's policy is also unclear, with a legislatively established review of the policy to occur after just 5 years of experience (by 2005).

To counter concerns about policy instability and long-term contracting, a variety of states are developing innovative approaches to require or encourage long-term contracting. In Connecticut, for example, a revised RPS was established that requires the electric utilities in that state to purchase at least $100 \mathrm{MW}$ of renewable electricity under long-term contract. Similarly, in several additional states including Nevada, New Mexico, and California, the RPS requires that suppliers purchase all renewable energy under long-term contract.

31 For a broader discussion of the need for long-term power purchase agreements, and the impact of policy design on these agreements, see Wiser and Pickle (1998). For information on the risks inherent in TREC systems that emphasize short-term trade, see Lemming (2003). 
In Massachusetts, meanwhile, the state's renewable energy fund has opted to offer long-term TREC price insurance to help facilitate project financing. Finally, in New York, policymakers decided to use a government-administered central procurement mechanism (somewhat similar to the UK's NFFO), at least initially, in part to overcome concerns about the ability and willingness of the private sector to enter into long-term contractual arrangements with renewable developers. Whether and under what conditions these strategies work effectively remains to be seen.

\subsubsection{Cost effectiveness}

Two additional costs are discussed here that were not covered under market efficiency: (1) administrative costs, and (2) the cost of free-riders.

The administrative costs of an RPS consist of at least two distinct activities: (1) tracking and verification, and (2) rules development and enforcement. US experience generally shows that these two costs are modest relative to the cost of the policy as a whole. Rules development and enforcement, for example, rarely requires more than a couple full-time equivalent staff on a long-term basis.

The cost of the tracking and verification system is variable, but is also not overwhelming. The largest and most expensive tracking system in the US covers the New England region (tracking all generation, not just renewable generation), and required $\$ 200,000$ of up-front capital and recovery of annual operating costs of $\$ 900,000$ to $\$ 2,400,000$ over five years (equating to a transaction fee that is as high as $\$ 0.0176 / \mathrm{MWh}$ ). The other tracking systems in operation in the US required substantially less funding.

Another issue of some concern is whether free-riders are able to benefit from the obligation system. US RPS design has sought to mitigate this concern in several ways. First, a number of RPS requirements are divided into separate resource tiers: one tier for new and more costly forms of renewable generation, and another tier for existing and less costly types of renewable energy. In this way, existing projects whose capital costs are already repaid are not able to generate substantial RPS-derived revenue. In still other cases, the RPS only applies to new renewable generation. Second, in those successful RPS policies, renewable energy is typically purchased under long-term contract. A single market-clearing TREC price is therefore not automatically provided to any and all generation, regardless of need. Instead, electricity suppliers issue competitive solicitations (tenders) to select projects with which to contract on a long-term basis; projects are typically selected on a least-cost basis, based on bids received, ensuring that different pricing structures are used for different projects. Suppliers generally use the TRECs so procured to meet their own obligations and, if excess TRECs are purchased, to sell on the open market. ${ }^{32}$ The most glaring exceptions are Massachusetts and Connecticut, where a number of generators are clearly obtaining RPS revenue from short-term TREC trade that exceeds their revenue needs. As noted earlier, this appears endemic to RPS markets where renewable energy demand exceeds supply, and short-term trade in TRECs dominates over long term contracting.

Given the two considerations above, it is clear that the majority of funds paid by end-use customers under the existing RPS policies are in fact making their way to directly support new renewable generation. Administration and tracking costs are not sizable, free riders do not appear to be a major concern in most instances, and most suppliers have (so far) opted to directly procure renewable energy rather than taking advantage of alternative compliance payments. There are, however, exceptions. Compliance costs in the Northeast, for example, are no doubt flowing to a significant degree to a limited number of existing renewable energy generators that are not in need of the magnitude of incremental revenue that is being gained.

32 There have been some concerns in Texas about the unwillingness of large suppliers to sell their TRECs on the open market, at a low price. Whether this is a reflection of market power/hoarding, or not, is unclear. 
Though this situation will ease somewhat over time, as increasing amounts of new renewable generation are required under the standard, it does create some concern about the cost effectiveness of certain state RPS policies.

\subsubsection{Stakeholder support for the system}

As with virtually all policy efforts, an RPS creates winners and losers. It is therefore not uncommon for renewable energy generators and advocates to hail the creation of an RPS, while obligated purchasers fight to mute the effectiveness of the policy.

Generally speaking, supporters of renewable energy policy in the US have voiced strong support for RPS programs. In fact, among the available and politically palatable renewable policy options in the US, the RPS receives the greatest amount of overall support. That is not to say that each individual state policy has been supported: those RPS requirements that are viewed as weak or ineffective are typically targeted for legislative or regulatory change and improvement (e.g., Maine, Arizona). Also note that a traditional feed-in tariff policy is not generally viewed as politically viable in the US, so support for an RPS in the US does not imply lack of support for a feed-in tariff approach. ${ }^{33}$

Supporters of more-costly forms of renewable generation (e.g., solar), on the other hand, sometimes have a somewhat ambivalent attitude towards RPS requirements that, due to competitive pressures, will not benefit their technologies. In the case of solar, however, advocates have been successful in creating solar-specific set asides in a number of recent state RPS requirements, ensuring that the benefits of the policy flow to a greater diversity of renewable industry stakeholders.

Obligated purchasers often resist RPS efforts, at least initially. In some instances, however, these purchasers have gained experience with renewable energy and have sometimes become supporters of the underlying policy over time. Such has been the case in Texas, Wisconsin, and some other states. Industrial electricity customers, meanwhile, have also been generally reluctant to embrace the RPS, or any renewable energy policy for that matter.

\subsection{Equity}

The principal equity-related concerns in the US have revolved around: (1) the possible need for a more aggressive federal renewable energy policy, (2) the treatment in inter-state trade in renewable energy, (3) the application of the policy to publicly owned electric utilities, and (4) electric rate impacts.

As long as states continue to play a sizable role in renewable energy deployment, there will be calls for federal action. Many of the benefits of renewable energy cross state boundaries: regional air emissions reductions, carbon abatement, economic development, and improvements in national security. As such, there are those who believe that aggressive state action inequitably penalizes the state's citizens for benefits that accrue nationally.

Similarly, state RPS policymakers often struggle with how to treat out-of-state renewable energy sources. Allowing such sources to qualify for an RPS will surely reduce costs and increase TREC liquidity, but will also dissipate the in-state environmental and economic development

33 California was, in fact, the first major jurisdiction to implement a successful feed-in tariff program under its implementation of PURPA in the 1980s. Since that time, concerns have surrounded the ultimate cost of that effort (and similar programs in other states), under which renewable energy generators were able to access very favorable long-term electricity contracts. In addition, the general political environment in the US lends greater support to policy approaches that encourage competition and perceived cost minimization, despite the plausible benefits of a feed-in approach. 
benefits of the policy. This conflict has led to a variety of solutions across states, as illustrated in Table 3.1

RPS policies in the US typically apply to investor-owned electric utilities and competitive energy service providers, but often exempt publicly owned electric utilities from the requirements. These publicly owned utilities supply approximately $25 \%$ of the electricity in the US, and exemption of these suppliers has led to equity concerns.

Finally, concerns about electric rate impacts, especially among sensitive industrial customers, has been pronounced in some states, despite the fact that state RPS requirements are typically predicted to have a modest impact on retail electricity rates. The result has been that several state RPS programs have specifically exempted certain industrial loads from the RPS, or have established low caps on the extra costs that may be imposed on these customers.

\subsection{Conclusions and lessons learnt}

RPS experience from the US has been decidedly mixed: some states have had success with the policy while others have struggled with poorly designed and implemented efforts. Clearly, RPS policy design is a complex process, and one that must be done with great care to create positive outcomes.

The most important lesson from US experience is the need for policy stability and long-term contracting, as detailed earlier. Where RPS-driven RE demand exceeds available supply, and short-term trade in TRECs dominates over long term contracting, RPS policies appear to be a costly and unstable way of achieving renewable energy objectives. In this regard, experience from New England appears to mimic that in the UK.

Other important pitfalls experienced in the US include (Wiser et al, 2004):

- Poorly balanced supply-demand conditions. Maine provides the quintessential example of a supply-demand imbalance, created by poor policy design. The Maine policy established a seemingly aggressive 30\% RPS. Unfortunately, eligible resources include a significant amount of existing renewable energy and high-efficiency natural gas cogeneration in New England. Existing supply therefore far exceeds the standard itself and, as a result, the RPS will do nothing to support new renewable energy development.

- Selective application of the purchase requirement. Some US states have only applied the RPS to a small segment of the state's electric market, muting the potential impacts of the policy. For example, in both Connecticut and Pennsylvania, initial RPS requirements applied to less than $5 \%$ of the total market (in both cases, subsequent revisions to the policies have rectified this problem). Not only does this violate the principle of competitive parity, it also ensures that the RPS will have only a marginal impact.

- Insufficient enforcement. Without adequate enforcement, electricity suppliers will surely fail to comply with the RPS. In this environment, renewable energy developers will have little incentive to build renewable energy plants. The enforcement rules of a number of US RPS policies are vague in their application, and in some cases adequate enforcement is seemingly lacking (e.g., Arizona and Nevada).

Other concerns, including poorly defined and unstable rules for resource eligibility and the eligibility of out-of-state generators, rigid verification mechanisms, and inadequate compliance flexibility, have also been experienced in some jurisdictions.

These experiences show that an effective RPS will generally be one in which: (1) strong political support and regulatory commitment exists, and that support is expected to continue over the duration of the policy, (2) clear and well-thought-out renewable energy eligibility rules are applied, (3) predictable long-term renewable energy targets are established that ensure new renew- 
able energy supply, (4) standards are achievable given permitting challenges, (5) credible and automatic enforcement ensures that the penalties exceed cost of compliance, and (6) the standard is applied to electricity suppliers that are credit-worthy and are in a position to enter into long-term contracts. It is also these design considerations that can lead to an RPS in which longterm contracts are offered.

Despite the mixed experiences, state RPS policies are likely to remain the predominant form of support for renewable energy in the US, at least in the near term. Existing policies will be redesigned to improve their effectiveness, and new states will be added to the RPS roster. Those policies that are already well designed will begin to encourage significant - though not massive growth in renewable energy capacity. 


\section{Conclusions}

\subsection{Main results and conclusions for each criterion}

In the previous chapters, the performance of quota obligation systems implemented in the UK, Sweden and the USA have been evaluated based on the following criteria:

- Effectiveness

- Market efficiency

- Certainty for the renewable energy industry

- Cost effectiveness

- Stakeholder support for the obligation system, and

- Equity.

This section presents the main results and overall conclusions for each criterion.

\subsubsection{Effectiveness}

The quota obligation systems analysed in the present study have almost all been in place for less than 5 years. Taking into account the lead time of several years before most new renewable energy projects can be put into operation, it is difficult at this stage to determine with a great level of certainty the effectiveness of these systems in terms of reaching their set RES-E targets.

First observations in Europe and the US show that generally the number of TRECs issued is (more than) sufficient for meeting the initial RES-E targets. Exceptions are the UK with a significant shortage of TRECs produced in 2004 (60\% of the target), and Flanders with a smaller shortage (95\% of the target) in 2004. Most US states are meeting their early RES-E targets, but this is not always the case: several US states have struggled due to aggressive targets, lack of long-term contracting, and/or insufficient enforcement (e.g., Massachusetts, Arizona, Nevada). Arguably, where targets have not been achieved, it has been primarily due to poor policy design and a lack of certainty for renewable energy producers; permitting difficulties have also arisen in a number of locations.

Even where the number of TRECs is adequate, however, obligation compliance is not always complete. Especially in Europe, strategic behaviour of obligated actors appears common and greatly influences the production and submission of TRECs. In Sweden and Wallonia, for example, some of the TRECs that are produced are not being used for meeting the initial quota obligations, but are instead banked for future years under the expectation that the value of the TRECs will increase. In the UK, the target has been set at a level too high to be reached in the short term, helping to keep the TREC price high.

An important policy objective is to stimulate new renewable energy capacity. The limited experience from the case studies presented in this report shows that the quota obligation systems are only beginning to have an effect on capacity additions, in part because of the young age of these policies. In Sweden, the production of electricity from renewable energy sources has significantly increased over the past two years, but this is caused mainly by an extension of already existing capacity and not through adding truly new capacity. This is not surprising in that extension of existing capacity often is the least cost and least risk option. In the UK, meanwhile, the obligation system has provided substantial impetus for new renewable energy development, and wind power capacity is expanding more rapidly than in the past. Finally, in the US, over 2000 MW of new renewable energy capacity has already been motivated - in part - by state obligation policies. 
These additions have mostly occurred where obligated actors have been willing and able to enter into long-term contracts with renewable energy generators. In Europe, where such contracts have been scarce under obligation policies, producers have had to rely on short-term profit maximization. Whether obligation systems that focus almost exclusively on short-term trade in TRECs can be effective in creating a climate for cost-effective, new renewable energy capacity additions remains to be seen.

\section{Conclusion}

Definite conclusions on the effectiveness of quota obligation systems in terms of reaching the set RES E targets cannot yet be drawn. Where targets have not been achieved, it has been primarily due to poor policy design and a lack of certainty for renewable energy producers; permitting barriers have also arisen. In addition, there are some instances of strategic behaviour of obligated actors leading to unwanted side effects. These teething problems may well be solved over time when the actors become more familiar with the system and market forces bring about a more stable equilibrium. In addition, several revisions are being proposed to address the problem of long-term security and to create a conducive environment for negotiating long term TREC sales contracts, which will also reduce the incentive for strategic behaviour. Experience in the US shows that if certificates are delivered under long-term agreements, the effectiveness of an obligation can be high and compliance levels can be reached. Whether and under what circumstances such long-term contracts are available will be a key determinant of success for obligation policies.

\subsubsection{Market efficiency}

One indicator of market efficiency is the extent to which individual actors can influence the TREC price. In Europe, the TREC market is still immature and therefore market efficiency is generally rather poor, but this also reflects the immaturity of the liberalized national electricity markets throughout Europe. In the UK this is caused by a limited number of obliged actors. In the US, the picture varies among the states. In those states where long term contracts can be concluded, producers are often competing for these contracts resulting in an efficiently working market with low prices (often for TRECs bundled with the underlying electricity). Short-term trade in TRECs is often limited in these instances, but this trade is not what is driving new renewable energy development, so limited liquidity is not of major concern. In other states, lack of TREC liquidity is a more significant concern.

Short-term TREC prices vary significantly among countries/regions as shown in Table 7.1 below.

Table 7.1 TREC prices per MWh in $€$ for several countries/regions

\begin{tabular}{lcll}
\hline Country/Region & $\begin{array}{c}\text { TREC price } \\
{[€ / \mathrm{MWh}]}\end{array}$ & Term & Date \\
\hline Wallonia & 92.0 & Short term & November 2004 \\
Flanders & 109.0 & Short term & December 2004 \\
United Kingdom & 68.4 & Short term & January 2005 \\
Sweden & 24.2 & Long term & March 2004 \\
Texas & 10.8 & Short term & Average 2004 \\
Massachusetts & 39.2 & Short term & Average 2004 \\
\hline
\end{tabular}

Note: exchange rates used are: $€=.688$ GBP,$€=9.1$ SEK and $€=1.3$ USD

The large price variation among regions partly reflects differences in the fundamental design of the obligation policies and differences in the marginal cost of RES-E supply, but these differences are also caused by differences in market efficiency. In the UK, for example, short-term TRECs trade at high levels because the policy has been designed such that the targets are not 
achieved, and TREC prices are therefore driven by the buy-out level. The market efficiency of such a system is likely to be low in that, at least in the short term, TREC prices are far higher than needed by producers to obtain a reasonable profit. At the same time, the lack of long-term contracting provides producers little revenue certainty, thereby requiring high short-term TREC prices to encourage supply.

Low short-term TREC prices, meanwhile, can be found typically in those regions where producers are able to conclude long term TREC sales contracts, and where short-term trade in TRECs is used to balance accounts rather than to finance new renewable energy capacity (low TREC prices are also found where eligible renewable energy supply exceeds obligation-induced demand). Yet again, this suggests the need for revenue certainty and long-term contracting to ensure that an obligation system drives new renewable energy capacity at a minimum cost. Where short-term trade in TRECs dominates, policymakers will may need to develop mechanisms to thwart strategic behaviour and to enhance market stability.

\section{Conclusion}

In Europe, market efficiency generally is rather poor because of the limited number of participating actors and/or producers, and because of the limited degree of long term contracting. It is expected that, over time, as the market size increases and as the systems are revised to facilitate long term contracting, market efficiency will improve leading to lower long and shortterm TREC prices. In the US, where the obligation system was introduced earlier and negotiating long-term contracts is more common, market efficiency is generally satisfactory in a number of states. In other states, however, short term TREC trade dominates, and that trade is sometimes at high prices that are more driven by penalty levels than by supply and demand. To some extent, this is a remarkable observation, contrary to what intuitively is perceived by many as efficient. If TRECs are delivered under long-term agreements, the TRECs are effectively withdrawn from the market and the price may not be known publicly. This hampers liquidity and transparency of the short term TREC market, but to the extent that renewable energy developers are able to deliver lower cost renewable generation with the certainty of a long-term contract, such contracting will lower the cost of compliance with the obligation and thereby increase efficiency.

\subsubsection{Certainty for the renewable energy industry}

Given the long time horizon for investments in new RES-E production capacity, generators have often needed long-term revenue certainty to be able to secure low cost financing. In a quotabased system, as already detailed, these revenues can be uncertain, because they come from a TREC market whose short-term market price varies with time. Therefore, a precondition for an effective obligation is that the government ensures a sufficient level of demand for renewable energy over a long enough time horizon to create some level of market certainty. This is, in turn, also a requirement for the existence of long term contracts, whose existence can ensure that generators are able to access lower cost financing. A long-term government commitment appears to be a key requirement for the proper functioning of the obligation system.

In Sweden, the limited duration of the obligation (until 2010) is reported to be a major source of uncertainty to the market, and therefore a long-term, post 2010, prolongation has been proposed. Similarly, in the UK, the recent confirmation of the extension of the quota obligation until 2015/16 was necessary to give greater confidence in the ROCs market. In the US, uncertainty on the duration or enforcement of the RPS exists in some states, and this uncertainty often coincides with a lack of long-term contracts.

Furthermore, short-term uncertainties, notably on TREC price levels, may influence market confidence. This seems to be an issue mainly in the UK, due to the specific design of the system. In the UK, the recycle value is an uncertain element in the market price for TRECs. The uncer- 
tainty in the recycle value is mainly caused by the unpredictable amount of ROCs produced by co-firing installations that can be placed on the market without long lead times, and by supplier credit risk (bankruptcy of suppliers). Both issues have been addressed in the recent review. Due to these uncertainties, the risk premium charged by suppliers is high. The market has already developed a number of derivatives for the ROC market, but the cost of these derivatives is high, given limited liquidity.

In Sweden, most biomass and hydro producers do not consider fluctuations in TREC prices a major risk, but instead as comparable to the risks related to other electricity price fluctuations. Moreover, in Sweden, prices can be expected to remain stable as long as most of the eligible production is (biomass) fuel-based, taking into account that marginal operating costs in biomass plants are higher than those for wind and hydro production. The situation may change over time, when the increase of the quota requires investment in new (wind) capacity, and consequently the overall price level is expected to increase.

Finally, governmental reviews of the system are also perceived as increasing market uncertainty, despite the government's stressing the limited scope of these reviews. This is related to the fact that revisions may influence the certificate price, and thereby affect the revenues of current producers.

\section{Conclusion}

A sufficient level of certainty for the renewable energy industry is imperative for a well functioning obligation system. A precondition is to set long term RES E targets: 10 years ahead appears to be the minimum horizon, which is already a long period from a political point of view. Uncertainty due to short term TREC price fluctuations is notably a problem in the UK due to the recycle payment. Revisions of the obligation system as a result of a review can also easily lead to greater uncertainty among RES E producers. This may limit the government's flexibility to adjust the system in the course of time.

\subsubsection{Cost effectiveness}

The theoretical considerations in Section 2.3 have shown that obligation systems have the potential to achieve a set RES-E target in a cost effective way, and provide an incentive for long term cost reductions, due to the role of competition. However, the system needs to be designed well to achieve these goals, which is a complex matter that is often not achieved.

A possible weakness of an obligation system is the overcompensation of low-cost producers. Practical experience to date shows that in Sweden, existing capacity may indeed have received more support than needed from the system. This may be due to the recent introduction of the system, and to the existence of a large amount of existing CHP capacity, which can easily switch between renewables and fossil fuels. In the UK, there is only a small share of previously built capacity eligible under the Renewables Obligation, so there is not much concern on free riders. However, the likely existence of high TREC prices for years to come will perhaps result in excess compensation for new renewable energy generators as well. In some US states, technology or long term vintage tiers are used to create submarkets with more homogenous supply and help prevent windfall profits; of course, such market segmentation can reduce liquidity in the market for TRECs.

Experience in the US also shows another way of improving cost effectiveness. In those cases where renewable energy is purchased under long-term contract, a single market-clearing TREC price is not automatically provided to all generation. Instead, suppliers issue competitive tenders to select projects with which to contract on a long-term basis. These projects are typically selected on a least-cost basis, ensuring that different pricing structures are used for different projects. Suppliers generally use the TRECs so procured to meet their own obligations and, if ex- 
cess TRECs are purchased, to sell on the open market. This tendering system is, in some ways, similar to the NFFO system previously employed in the UK. Because the tenders are organized by electricity suppliers who face a penalty if they are unable to comply with the obligation, however, these suppliers have a strong inventive to contract with projects that will subsequently come on line. While the unpredictability of the tenders might be a drawback from the producers' point of view, a long-term obligation with long-term targets will ensure that regular tenders take place.

Another concern related to cost effectiveness is how the revenues from the obligation system are spent. These revenues may consist of TREC payments to generators, penalty payments to the government, transaction costs paid to suppliers (by consumers and/or generators), and VAT payments to the government.

Ideally, a high compliance rate and low transaction costs ensure that the generators benefit most from the TREC payments. In some US states this seems to be the case. In general it is very sensitive to the design of the system.

- In Sweden's first obligation year, only half of the total revenue flowed to the renewable generators, partly caused by a low compliance rate and thus significant penalty payments to the State. Retail suppliers received $17 \%$ of total TREC revenue, for transaction costs and profits. To improve the cost-effectiveness of the system, there is a proposal to impose the obligation on suppliers (and put pressure on transaction costs by including TRECs in the electricity price) and to recycle the revenues derived from penalty payment to the renewable energy sector.

- In the UK, the system has been designed such that the penalty level, and level of overall compliance, sets the price of TRECs. The advantage of the recycling fund is that generators receive a larger incentive than otherwise might be the case. However, because of the uncertainty in the level of recycling, there is some indication than some of this value is being retained by suppliers, and is not flowing through to renewable energy producers. Moreover, to the extent that the market price of TRECs is uncertain, suppliers have only been willing to enter into long-term contracts with producers at deeply discounted prices.

\section{Conclusion}

Obligation systems can encourage cost reduction and competition, but its design is more complex than a feed-in tariff. An obligation system will generally stimulate the lowest cost and least risky renewable technologies, thereby allowing a set target to be met in an efficient way. Moreover, the total costs of an obligation system can be capped by the size of the quota and the level of the penalty. Short-term TREC markets can lead to overcompensation of existing capacity or low-cost production, but this can be countered in several ways. First, by technologyspecific (investment) subsidies, creating a more level playing field in the TREC market, or by developing technology or vintage tiers under the obligation system. Furthermore, the cost effectiveness of an obligation system can be improved by (1) using penalty revenues to stimulate renewables, instead of flowing to the state; and/or (2) encouraging a high level of compliance by setting a relatively high penalty. The system employed in various US states, where obliged suppliers offer long-term contracts to producers in competitive tenders, seems to have the benefit of combining effectiveness and cost efficiency. Without the use of some of the mechanisms described above, and absent careful design, international experience shows that obligation systems will not lead to cost-effective outcomes.

\subsubsection{Stakeholder support for the obligation system}

There seems to be a reasonable level of support from most key stakeholders for the obligation system, although this support is often a result of poor experience with the previous RES-E support scheme (if any). From the producer's perspective, obligation systems are generally per- 
ceived to be more sustainable in the long term in the countries in which they have been established, less dependent on (unpredictable) changes in government policies, at least compared to other instruments such as feed in tariffs and investment subsidies.

However, not all producers gain equally from the system. Less competitive technologies (e.g., solar) receive few benefits from an obligation system, unless technology tiers are employed. Nonetheless, from the analysis presented in this report, it appears that these producers are lobbying for special treatment rather than completely opposing the system. The obliged suppliers, on the other hand, are, at least initially, rather sceptical of obligation systems, but the experience in the US reveals that over time, when they get more familiar with the system, supplier may tend to accept the system.

\section{Conclusion}

Generally speaking, there is sufficient support for the obligation system from the key renewable energy stakeholders, both in Europe and in the US. The obligation system is often perceived to provide more long term security, at least relative to earlier support policies in the countries in which obligation systems have been introduced, because obligation systems may be less prone to changing political circumstances, compared to other RES-E support instruments. Most criticism therefore is not so much directed against the system itself, but more against specific design elements of the system. Those that have initially opposed obligation systems have generally been the obliged suppliers and industrial customers. In addition, in those countries with well-functioning feed-in tariff systems, obligation systems are often opposed by renewable energy industry lobbies, which have grown accustomed to the existing support system and do not want to risk a new and uncertain policy.

\subsubsection{Equity}

A fair distribution of costs and benefits resulting from the obligation scheme is an important aspect for ensuring the long-term sustainability of the system. The review of the systems in the UK, Sweden and the US reveals the following inequalities, which possibly could jeopardize the long-term sustainability of the obligation policies:

\section{Large vs. small producers}

All case studies show that small renewable energy producers are likely to face additional barriers in an obligation system, because they are less able to absorb the risk inherent in an obligation system. Furthermore, vertically integrated companies that hold supply licenses and are able to self-develop renewable energy projects may have an advantage, as they are better able to absorb risk internally. Finally, given the transaction costs in the market, owners of large renewable energy plant have a distinct advantage over owners of smaller-scale installations.

\section{Exemptions}

The exemption of specific groups from the quota obligation, such as some industrial consumers (electricity intensive industry) in Sweden or publicly owned electricity utilities in the US, might be a cause for equity concerns, but generally these exemptions have been required to gain acceptance of the quota obligations.

\section{Inequalities among technologies}

As noted earlier, an obligation system us typically more favourable to the less expensive technologies, although the 'losers' may differ between countries (wind in Sweden, biomass in the UK). This may be a logical consequence of a political objective to stimulate RES-E in the most cost effective way, regardless of the type or source. If there are reasons to provide additional support to specific technologies, however, experience shows that this can still be done without severely distorting the TREC market. 
Conclusion

Equity aspects should be duly taken into account when designing a quota obligation system to ensure sufficient long-term support from the main stakeholders. Obligation systems seem to be less suited for small RES-E producers. Other important aspects are the exemptions of particular groups from the system, and the creation of a level playing field for RES-E technologies.

\subsection{Recommendations on the design of a quota obligation}

Based on the experience gained with the obligation/TREC systems in the USA and Europe, the following recommendations can be made regarding the main design elements of a successful policy:

1. Market liquidity. Introduction of an obligation system should only be considered if a sufficiently liquid TREC market can be created in which a large number of market actors exist, none of whom can individually influence the TREC price.

2. Long term targets. Targets for the obligation must be set at least 10 years ahead (preferably 15 or more years), in order to provide the certainty necessary for RES-E producers to conclude long term TREC sales contracts. Long term targets are perhaps the most important element for a well functioning obligation system and are imperative for attracting substantial amounts of new investments in RES-E capacity.

3. Balanced targets. RES-E targets must be set taking into account current and future supplydemand conditions. This means that, on the one hand, targets must exceed existing supply and, on the other hand, must be achievable at reasonable cost.

4. Differentiated technology support. With ambitious targets or limited resource potentials, TREC prices can achieve high levels and thus decrease the cost effectiveness of the system. This can be prevented by either introducing technology or vintage tiers, or by providing additional subsidies to the more expensive technologies.

5. Obliged actor. If the obligation system is the main RES-E policy instrument, the obligation should be placed with the electricity suppliers/utilities, thereby preventing additional administrative costs.

6. Flexibility. The stochastic nature of renewable energy supply requires that some flexibility should be built into the system to be able to deal with stochastic supply of TRECs. The obligation system can be made flexible through allowing banking and borrowing of TRECs and through including the option to buy out (part of) the obligation by paying a penalty. However, to prevent strategic behaviour, these options must be introduced in a balanced manner; it is recommended to limit borrowing to three months and banking to a maximum of $25 \%$ of the obligation.

7. Penalty revenues. The penalties collected from non compliance should not be directly recycled back to the TREC market because this can add to the already existing uncertainty about future TREC prices and can seriously hamper the establishment of long term TREC sales contracts. However, the use of these revenues for general purposes could jeopardize the credibility of the obligation system and it is therefore recommended that these revenues be used for further research and development on the least competitive RES-E technologies, or for investment or production subsidies for new RES-E generation. 
8. Harmonization. To increase the potential for future international trade in TRECs it is recommended that resources eligibility for the obligation system be in line with the EU Renewables Directive.

9. Government commitment. Strong and long-term political commitment is essential for ensuring a well functioning obligation system. This commitment can be expressed by applying clearly defined monitoring and verification rules for eligible resources and by defining adequate enforcement rules in case of non-compliance; as noted earlier, long-term targets are also essential.

\subsection{Feasibility of introducing a quota obligation system in the Netherlands}

In 2002-2003, the main support scheme for renewables in The Netherlands has seen major changes, shifting from a voluntary demand incentivised by a tax exemption to a feed-in premium tariff scheme, the MEP premium. The Dutch Government does not intend to introduce another large revision of the support scheme in the near future, as this is expected to harm confidence in the market.

The evaluation of international experiences with the obligation system gives rise to a mixed picture. Although an obligation in theory is effective and cost effective, it seems too early to conclude that the system delivers these promises in practice. On the one hand this is due to the limited period of implementation that makes it hard to distinguish between the direct effect of the system and some teething problems that will be solved in due time. On the other hand, the conclusion can be drawn that the obligation is a complex system, which will only function well if designed carefully.

It does seem worthwhile, however, to continue monitoring the experiences with the obligation system abroad, because this will further reveal whether the system is indeed effective and cost effective in practice. In the longer term, e.g. beyond 2010, the introduction of an obligation system in the Netherlands could be considered for the following reasons.

- The theoretical analysis points out that an obligation system is more likely to achieve set RES-E targets, and that the combination of the quota and the penalty ensure that the total costs of the system are capped.

- The infrastructure, required for a TREC market, is already in place in The Netherlands, thanks to the use of certificates in the past, and of Guarantees of Origin at present. Experience has already been gained, indicating that the market would be liquid enough and the number of market actors would be sufficient. However, just as in the UK, there are some vertically integrated suppliers, which could, depending on system design, have an advantage over independent producers.

- International trade in TRECs would potentially be of interest for The Netherlands. For the EU indicative targets for 2010, most Member States will choose to prioritise domestic production. As such, the relevance of international trade would depend on national and European ambitions after 2010. If such targets were agreed upon, the Netherlands would probably be able to reduce costs by importing TRECs from countries where low-cost renewable resource potential is high. Note however that this trade can take place anyway, based on Guarantees of Origin, without having to shift to an obligation system in the Dutch market. On the other hand, if the Swedish/Norwegian initiative to develop a joint TREC market would expand to other countries as well, this could lead to a larger and more liquid market. 


\subsection{Finally: convergence of different support schemes?}

Often, in literature, a quota obligation system and a feed in tariff system are presented as two different instruments to stimulate renewable electricity and therefore a comparison of advantages and disadvantages of the two systems easily results in placing them opposite to each other. However, in practice the basic concepts of both the obligation system and the feed in system have been refined in such a way that the two systems are gradually moving towards each other. Examples are:

- Introduction of technology bands in an obligation system to establish different technology tiers in order to improve the cost effectiveness of the system

- Promoting the establishment of long term agreements between renewable electricity producers and electricity suppliers in the obligation system ideally creates a situation comparable to the long term security offered to producers in a feed-in system

- The cost effectiveness of a feed-in system can be improved by a gradual reduction over time of the tariffs. In an obligation system, the market stimulates technology cost reductions.

- Setting a budget ceiling for the feed in system, possibly linked to the achievement of policy targets. This last option is being implemented for the MEP system in The Netherlands.

An important difference between the two systems however remains, namely that an obligation system relies more on market forces whereas the feed-in system is based on a greater involvement of the government. In a obligation system, the suppliers are the ones that should negotiate long term contracts, preferably through a system of tendering. The evaluation in this report has revealed that the choice between the two systems is to a large extent determined by cultural factors.

Extrapolating this trend could lead to the design of a hybrid system, combining feed-in tariffs, such as the MEP, with an obligation. Reduced MEP premiums could function as minimum TREC prices in a system where the obligation is placed upon suppliers. This would introduce incentives towards market efficiency while maintaining some of the long-term certainty offered by a feed-in tariff. Moreover, the quota would provide a ceiling to the amount of production, thereby preventing high costs of subsidizing more RES-E production than required for the target $^{34}$. Finally, the MEP premiums would flatten the supply curve in the obligation and offer differentiated support for renewable technologies, thereby improving the cost effectiveness of the system.

\footnotetext{
${ }^{34}$ For the same purpose, the MEP legislation is currently being revised in order to introduce annual ceilings to the available subsidy.
} 


\section{References}

Åstrand K. (2004): 'Hur ändamålsenligt är elcertifikatsystemet för att främja ökad tillförsel av el från förnybara energikällor på lång sikt? ['How apt is the renewable electricity certificate system for promoting an increased supply of electricity from renewable energy sources in the long term?'], Environmental and Energy System Studies, Lund University. Paper commissioned by the SEA

Bergek A. (2004): 'Elcertifikatsystemet och innovationssystemen inom förnybar energiteknik' ['The renewable electricity certificate system and the innovation systems within renewable energy technology '] paper commissioned by the SEA

Dijk, A.L. van, L.W.M. Beurskens, M.G. Boots, M.B.T. Kaal, T.J. de Lange, E.J.W. Sambeek and M.A. Uyterlinde (2003): Renewable Energy Policies and Market Developments ECN-C--03-029

European Union (2001): 'Directive of the European Parliament and of the Council on the promotion of electricity produced from renewable energy sources in the internal electricity market', 2001/77/EC, Brussels.

ENDS, 2005: Ireland shifts green electricity support system, http://www.environmentdaily.com/articles/index.cfm?action=article\&ref=18562

Jansen, J.C. and M.A. Uyterlinde (2004): A fragmented market on the way to harmonization? EU policy-making on renewable energy promotion. Energy for Sustainable Development, 8(1), p. 93-107.

Kåberger T, T. Sterner, M. Zamanian and A. Jürgensen: 'Economic efficiency of compulsory green electricity quotas in Sweden' paper commissioned by the SEA

Langniss, O. and R. Wiser (2003): 'The Renewables Portfolio Standard in Texas: An Early Assessment'. Energy Policy, 31, 527-535.

Lauber, V., 2004: 'REFIT and RPS: options for a harmonized community framework', Energy Policy 32(2004) 1405-1414.

Lemming, J. (2003): 'Financial Risks for Green Electricity Investors and Producers in a Tradable Green Certificate Market'. Energy Policy, 31, 21-32.

Linden van der et al: Guarantees of Origin as a tool for renewable energy policy formulation. September 2004, ECN-C-04-078

Menanteau, Philippe, Dominique Finon and Marie-Laure Lamy (2003): 'Prices versus quantities: choosing policies for promoting the development of renewable energy, ' Energy Policy 31 (2003), pp. 799-812.

Nilsson L J, Johansson B, Åstrand K, Ericsson K, Svenningsson P and Börjesson P. 'Seeing the wood for the trees: 25 years of renewable energy policy in Sweden. Energy for Sustainable Development'. 2004; 8:67-81.

Petersik, T. (2004): State Renewable Energy Requirements and Goals: Status Through 2003. Washington D.C.: Energy Information Administration.

Sawin, J. (2004): National Policy Instruments; Policy Lessons for the Advancement \& Diffusion of Renewable Energy Technologies Around the World, Thematic Background Paper no. 3 for Renewables 2004 in Bonn, http://www.renewables2004.de

SEA (2004a): 'Översyn av elcertifikatsystemet Delrapport etapp 1' ['Review of the Renewable Electricity Certificate System - Report step 1'], available at www.stem.se 
SEA (2004b): 'Översyn av elcertifikatsystemet Delrapport etapp 2' ['Review of the Renewable Electricity Certificate System - Report step 1'], available at www.stem.se

SEA (2004c): 'Konsekvenserna av en utvidgad elcertifikatmarknad' ['The consequences of an extended renewable electricity certificate market '], available at www.stem.se

SOU 2001:77 (2001): Swedish Government Official Report Series. (2001) 'Handel med elcertifikat - ett nytt sätt att främja el från förnybara energikällor' ['Trade with electricity certificates - a new way of promoting electricity from renewable energy sources ']. Stockholm

Swedish Government (2002): Government Bill 2002/03:40 'Elcertifikat för att främja förnybara energikällor' ['Renewable Electricity Certificates promoting renewable energy'].

Swedish Government (2003): Government Bill 2003/04:42 'Torv och elcertifikat' [Peat and Renewable Electricity Certificates].

Söderholm P. (2004): 'Elcertifikatsystemets förmåga att främja kostnadseffektivitet och teknisk utveckling ['The capacity of the renewable electricity certificate system to promote cost effectiveness and technical development], paper commissioned by the SEA

Uyterlinde et al; Guarantees of Origin and multiple counting of electricity from renewable sources; September 2004, ECN-C-04-098

Verbruggen, A. (2004): 'Tradable green certificates in Flanders (Belgium)', in Energy Policy, Vol. 32, 165-176.

Wiser, R. and S. Pickle (1998): 'Financing Investments in Renewable Energy: The Impacts of Policy Design'. Renewable and Sustainable Energy Reviews, 2, 361-386.

Wiser, R., K. Porter and R. Grace (2004): 'Evaluating Experience with Renewables Portfolio Standards in the United States'. Mitigation and Adaption Strategies for Global Change. Accepted and in press. 


\section{Summary in Dutch}

In opdracht van het Ministerie van Economische Zaken heeft ECN, in samenwerking met partners in het Verenigd Koninkrijk, Zweden en de Verenigde Staten, een evaluatie uitgevoerd van de ervaringen opgedaan in het buitenland met het instrument van een verplicht aandeel voor duurzame energie. De uitkomsten van de studie geven geen eenduidig beeld. Hoewel een verplichting, in combinatie met een groencertificaten systeem, in theorie effectief en kosten effectief is, kan op basis van de ervaringen tot nu toe nog niet gesteld worden dat deze beloften helemaal worden waargemaakt. Enerzijds is dit een gevolg van de recente datum waarop verplichtingssystemen zijn geïmplementeerd en de dus nog beperkte periode waarin ervaring is opgedaan, waardoor sommige effecten nog niet geheel duidelijk zijn, en men nog te kampen heeft met aanloopproblemen. Anderzijds kan geconcludeerd worden dat een verplichting een complex instrument is, wat alleen goed kan functioneren bij een zorgvuldig ontwerp. Het is zeker de moeite waard om de ervaringen in het buitenland te blijven monitoren, om zo meer te kunnen leren over de effectiviteit en kosten effectiviteit van een verplichtingssysteem in de praktijk. Er is ook een aantal redenen waarom de invoering van een verplichtingssysteem op termijn, na 2010, voor Nederland interessant zou kunnen zijn. Tenslotte is er een tendens zichtbaar naar het verfijnen van het ontwerp van beleidsinstrumenten voor stimulering van duurzame energie. Dat leidt tot een convergentie tussen verplichtingen en terugleververgoedingen, hoewel de rol van de markt in beide systemen verschillend blijft.

\section{S.1 Wat is een verplichtingssysteem?}

De studie had tot doel het evalueren van de ervaringen opgedaan met bestaande verplichtingssystemen in Europa en daarbuiten, het analyseren van de belangrijkste ontwerp elementen van een groencertificaten systeem en het analyseren van de mogelijke rol van een verplichtingssysteem in het lange termijn duurzaam energiebeleid in Nederland en Europa.

Een verplichtingssysteem is een instrument ontwikkeld om de productie van elektriciteit opgewekt met duurzame bronnen te bevorderen, en omvat een wettelijke verplichting om een bepaald aandeel van de totale elektriciteitsconsumptie te voorzien met duurzame elektriciteit. De verplichting kan in principe gelegd worden ergens in de keten van productie tot eindgebruiker, maar ligt in de praktijk meestal bij het distributiebedrijf. Verplichtingssystemen zijn geïmplementeerd in Australië, Japan, de Verenigde Staten, het Verenigd Koninkrijk, Zweden, België, Italië en Polen; Roemenië heeft plannen om een verplichting in te voeren.

Om de partij met een verplichting meer flexibiliteit te geven in de wijze waarop de verplichting gehaald kan worden, is er vaak een koppeling aan een systeem van groencertificaten, ofwel TRECs (Tradable Renewable Electricity Certificates). Producenten van duurzame elektriciteit krijgen groencertificaten op basis van de hoeveelheid geproduceerde elektriciteit. Deze certificaten worden verkocht, tegen een zekere prijs, aan de partij met een verplichting (direct of via een certificatenmarkt), die de certificaten vervolgens gebruikt om aan te tonen dat aan de verplichting is voldaan. Bij een goed functionerende groencertificatenmarkt bepalen aanbod van en vraag naar certificaten de prijs. Uit de extra inkomsten van de verkoop van de certificaten, kan de producent de meerkosten voor duurzame elektriciteitsproductie bekostigen.

Uit de evaluatie blijkt een grote diversiteit in het ontwerp van het verplichtingensysteem in de verschillende landen. Verschillen in de hoogte van de verplichting en de boete kunnen voor een groot deel verklaard worden uit verschillen in potentiëlen en ambitieniveau. Andere verschillen treden op in de dekking van technologieën, de geldigheidsduur van certificaten, de regels voor internationale handel, en de besteding van boete opbrengsten. Opvallend is dat de keuze voor 
een verplichtingssysteem niet gemotiveerd lijkt door de mogelijkheden voor internationale handel in groencertificaten, maar met name wordt bepaald door de cultuur en de ervaringen met eerdere instrumenten voor het stimuleren van duurzame energie.

In de studie is een gedetailleerde evaluatie uitgevoerd van het functioneren van het verplichtingssysteem in het Verenigd Koninkrijk, Zweden en de Verenigde Staten op basis van de volgende criteria:

- Effectiviteit in termen van het halen van de verplichting

- Efficiency van de groencertificaten markt

- Mate van zekerheid die het systeem kan bieden aan de producenten van duurzame elektriciteit

- Kosten effectiviteit

- Steun van marktpartijen voor het verplichtingensysteem

- Eerlijke verdeling van kosten en baten over de verschillende stakeholders.

\section{S.2 Ervaringen met verplichtingssystemen}

De ervaringen in het Verenigd Koninkrijk met het verplichtingssysteem zijn tot nu toe niet duidelijk positief. Het systeem is ingevoerd in april 2002. De verplichting ligt bij de distributiebedrijven en doelstellingen lopen geleidelijk op van 3\% in 2002 tot $15.4 \%$ in 2015 . Groencertificaten kunnen gespaard worden voor een volgende periode tot een maximum van $25 \%$ van de verplichting. De boete voor niet voldoen aan de verplichting bedraagt in 2005/6 circa $€ 47$ per MWh. Duurzame energie geproduceerd buiten het Verenigd Koninkrijk kan geen groencertificaten krijgen.

Een groot probleem in het ontwerp van het systeem in het Verenigd Koninkrijk betreft de wijze waarop de boete opbrengsten teruggesluisd worden in het groencertificaten systeem. Dit gebeurt door de totale boete opbrengsten aan het eind van het jaar terug te geven aan de partijen met een verplichting, naar rato van de omvang van de verplichting en de mate waarin partijen voldaan hebben aan hun verplichting. Hierdoor wordt een extra onzekerheid geïntroduceerd in het systeem, omdat partijen met een verplichting een inschatting moeten maken wat ze aan inkomsten zullen krijgen uit de boete opbrengsten, en dit vergelijken met de boete die ze moeten betalen bij het niet halen van de verplichting. Het leidt zelfs tot een prikkel om niet (volledig) aan de verplichting te voldoen, om daarmee boete opbrengsten te creëren. Deze inherente onzekerheden leiden tot hoge risico premies en een matig investeringsklimaat. De bijzondere manier waarop het systeem is opgezet heeft ertoe geleid dat in 2003 slechts $60 \%$ van de verplichting is gehaald. De rest is afgekocht door het betalen van de boete.

In Zweden is het verplichtingssysteem ingevoerd in 2003. De verplichting ligt bij de eindgebruikers en doelstellingen zijn vastgesteld van $7.4 \%$ in 2003 oplopend tot $16.9 \%$ in 2010 . Sparen van groencertificaten kan ongelimiteerd. $\mathrm{Na}$ een jaar is er een evaluatie geweest waarbij aanbevelingen zijn gedaan om een aantal tekortkomingen in het systeemontwerp te verbeteren. De belangrijkste aanbeveling betreft het formuleren van doelstellingen voor de lange termijn. De evaluatie gaf aan dat de huidige doelstellingen tot 2010 onvoldoende lange termijn zekerheid biedt aan producenten om substantiële nieuwe investeringen te kunnen genereren in duurzame energie technologie. Het voorstel is om doelstellingen te formuleren tot en met 2015.

Een andere belangrijke aanbeveling was om de verplichting, die nu ligt bij de eindgebruiker, te plaatsen bij de energiedistributie bedrijven. In de praktijk gebeurt dat nu al. Eindgebruikers zijn over het algemeen te klein om de administratieve lasten van het managen van een verplichting te dragen en vragen het distributiebedrijf dit voor hen te doen. Echter, dit wordt door de belasting aangemerkt als het verlenen van een dienst waarover 17\% BTW wordt geheven, wat het systeem minder kosten effectief maakt. 
In de Verenigde Staten is een verplichtingssysteem (RPS - Renewables Portfolio Standard) ingevoerd in 18 staten, in de meeste staten gekoppeld aan een groencertificaten systeem. De ervaringen met de RPS in deze staten zijn verschillend. Het systeem blijkt vooral goed te werken in die staten waar een omgeving is gecreëerd waarbij lange termijn zekerheid geboden kan worden aan de producenten van duurzame elektriciteit. In deze staten blijkt het afsluiten van lange termijn verkoop contracten voor certificaten tussen producenten en partijen met een verplichting zeer gebruikelijk. De spotmarkt voor certificaten wordt dan alleen gebruikt voor het in balans brengen van korte termijn onevenwichtigheden tussen vraag en aanbod. Lange termijn doelstellingen en een duidelijke commitment van de overheid om de verplichting ook af te dwingen (opleggen van voldoende hoge boetes bij het niet voldoen aan de verplichting) blijken essentiële ontwerp elementen te zijn om dit te bereiken.

\section{S.3 Conclusies van de evaluatie}

De verplichtingssystemen in het Verenigd Koninkrijk, Zweden en de Verenigde Staten zijn geëvalueerd aan de hand van de criteria effectiviteit, efficiency, mate van zekerheid, kosten effectiviteit, steun van marktpartijen en eerlijke verdeling. Hieronder volgen de belangrijkste conclusies per criterium.

\section{S.3.1 Effectiviteit: zorgt het systeem voor een groei in de elektriciteit opgewekt met hernieuwbare bronnen?}

In principe zouden een voldoende hoge boete bij het niet voldoen aan de verplichting in combinatie met een realistisch niveau van de verplichting en een lange termijn doelstellingen moeten leiden tot een effectief systeem, in de zin dat aan de vastgestelde verplichting voldaan wordt. De evaluatie van de effectiviteit in de praktijk is echter nog moeilijk vanwege de beperkte ervaring $(<5$ jaar $)$ met het verplichtingssysteem.

In Europa is de ervaring dat het aantal uitgegeven certificaten meestal voldoende is voor het halen van de gestelde verplichting, maar niet in alle gevallen worden deze certificaten ook in voldoende mate ingeleverd. In plaats daarvan wordt gekozen voor het (voor een deel) voldoen aan de verplichting door middel van het betalen van de boete. Dit wijst op strategisch gedrag (banking) in de verwachting dat de prijzen van de certificaten gaan stijgen. De achterliggende reden zou kunnen zijn het behalen van korte termijn winsten bij gebrek aan lange termijn zekerheid. In het Verenigd Koninkrijk werd in 2004 slechts $60 \%$ van de verplichting gehaald, niet zozeer vanwege strategisch gedrag maar als direct gevolg van het feit dat boete opbrengsten direct worden teruggesluisd naar het systeem en daardoor het niet geheel halen van de doelstelling 'beloont'.

Als we kijken naar de groei in nieuwe hernieuwbare productiecapaciteit, is het beeld gemengd. In het Verenigd Koninkrijk en in een aantal staten van de VS is deze groei zeker zichtbaar, zij het ten dele ook onder invloed van flankerend beleid. In Zweden is in het eerste jaar dat het systeem operationeel was voornamelijk bestaande capaciteit uitgebreid. Dit ligt ook in de lijn der verwachting, omdat dat een goedkopere en minder riskante manier is om aan de verplichting te voldoen.

\section{S.3.2 Werkt de groencertificatenmarkt efficiënt?}

De verwachting is dat een groencertificatensysteem leidt tot concurrentie en daarom een efficiente manier is om duurzame elektriciteit te stimuleren. De handel in TRECs moet in principe leiden tot een efficiënt werkende markt en daardoor zouden lange termijn prijzen redelijk voorspeld kunnen worden. 
De praktijk is echter iets weerbarstiger. De efficiency van de groencertificaten markt blijkt tot nu toe in Europa meestal (nog) matig te zijn vanwege het beperkt aantal marktpartijen of producenten, maar ook vanwege het ontbreken van lange termijn zekerheid voor producenten van duurzame energie.

In Europa zijn grote verschillen in de TREC marktprijzen. Hoewel dat ten dele een gevolg is van de verschillen in ambitieniveau van de verplichting en de verschillen in de kosten van de duurzame opties, liggen er ook verschillen in efficiency aan ten grondslag. In het Verenigd Koninkrijk, bijvoorbeeld, liggen de TREC prijzen erg hoog, omdat het systeemontwerp impliceert dat de doelstellingen niet gehaald kunnen worden, wat leidt tot marktprijzen boven het niveau van de boete. Waarschijnlijk zijn de TREC prijzen hoger dan wat strikt genomen nodig is om de producenten een redelijke winstmarge te geven, maar is deze extra marge nodig als risicopremie.

In de Verenigde Staten is het beeld gemengd. De minder efficiënte groencertificatenmarkten worden gedreven door korte termijn handel, wat kan leiden tot hoge prijzen, tegen het boeteniveau aan. De meest efficiënte markten, daarentegen, werken op basis van lange termijn contracten tussen energiebedrijven en producenten, die in competitie verkregen zijn. Hierbij speelt (korte termijn) prijsvorming op TREC markt een ondergeschikte rol. In deze markten is de liquiditeit dus ook minder belangrijk; er wordt alleen gehandeld om balansen kloppend te maken. Dit is een enigszins verassende observatie, omdat deze markten niet transparant zijn - een groot deel van de handel vindt bilateraal plaats. Echter, de lange termijn contracten geven producenten de zekerheid nodig om tegen lagere kosten te kunnen produceren, en daardoor kan de verplichting op een efficiëntere manier gehaald worden.

\section{S.3.3 Biedt een verplicht aandeel voldoende zekerheid voor producenten?}

Lange termijn doelstellingen zijn een belangrijke ontwerp-eis voor een verplichtingssysteem. Zulke doelstellingen waarborgen de vraag naar TRECs en dus de opbrengsten voor producenten.

Uit de evaluatie van verplichtingssystemen blijkt dat lange termijn toezeggingen met betrekking tot het instandhouden van het systeem essentieel is voor een goed functioneren van het systeem. De verplichtingen zouden minstens voor tien jaar moeten worden vastgesteld, hoewel dat in politiek opzicht een lange periode is. Zowel in het Verenigd Koninkrijk als in Zweden zijn onlangs doelstellingen tot 2015 voorgesteld, omdat is gebleken dat doelstellingen voor een kortere termijn tot teveel onzekerheid, en dus inefficiëntie, leidt in de groencertificaten markt.

Andere onzekerheden die een rol kunnen spelen in de werking van een verplichtingssysteem hebben betrekking op korte termijn prijsschommelingen en evaluaties. Het eerste wordt alleen als een wezenlijk punt gezien in het Verenigd Koninkrijk, door de onzekere 'recycle value' die een substantiële component in de TREC prijs vormt. Het tweede is een meer algemeen verschijnsel. Marktpartijen zijn erg gevoelig voor evaluaties en bijstellingen van het systeem. Dit is een direct gevolg van het feit dat ingrepen een effect kunnen hebben op de marktprijs en zo ook de bestaande producenten kunnen treffen. Het impliceert dat de overheid, na de start van het systeem, weinig flexibiliteit meer heeft, en dat de grote lijnen van het systeem nauwelijks meer aangepast kunnen worden.

\section{S.3.4 Is een verplicht aandeel kosten effectief?}

Theoretische analyse geeft aan dat een verplichtingssysteem in principe in staat is om een gegeven verplichting zo efficiënt mogelijk te behalen, en dat de concurrentie op de markt een prikkel is voor kostenreductie op de langere termijn. Dit gaat echter alleen op voor een goed ontworpen systeem, wat gegeven de complexiteit van het instrument, niet eenvoudig is. 
Figuur S.1 illustreert de theoretische verschillen in kosten effectiviteit tussen een verplichtingssysteem en een systeem van terugleververgoedingen (feed-in tariffs).

- In het algemeen stimuleert een verplichtingssysteem de goedkoopste en minst riskante technologieën, waardoor de doelstelling op de meest efficiënte wijze behaald kan worden. Daarnaast vormen de omvang van de doelstelling en de hoogte van de boete een natuurlijke bovengrens aan de totale kosten. Als de aanbodcurve een steil verloop heeft, doordat relatief dure technologieën nodig zijn voor het behalen van de verplichting, kan een relatief hoge evenwichtsprijs leiden tot grote winsten bij de producenten met lage kosten.

- Een systeem van terugleververgoedingen wordt meestal gedifferentieerd per technologie en vermijdt zulke overwinsten, mits voldoende categorieën onderscheiden worden. Het bepalen van de hoogte van de vergoedingen is het echter problematisch, omdat de informatie over de kosten grotendeels aangeleverd wordt door partijen die belang hebben bij een redelijke vergoeding. Daarnaast kan het 'open einde' karakter van dit systeem leiden tot het overschrijden van de doelstelling, tegen bijbehorende kosten.
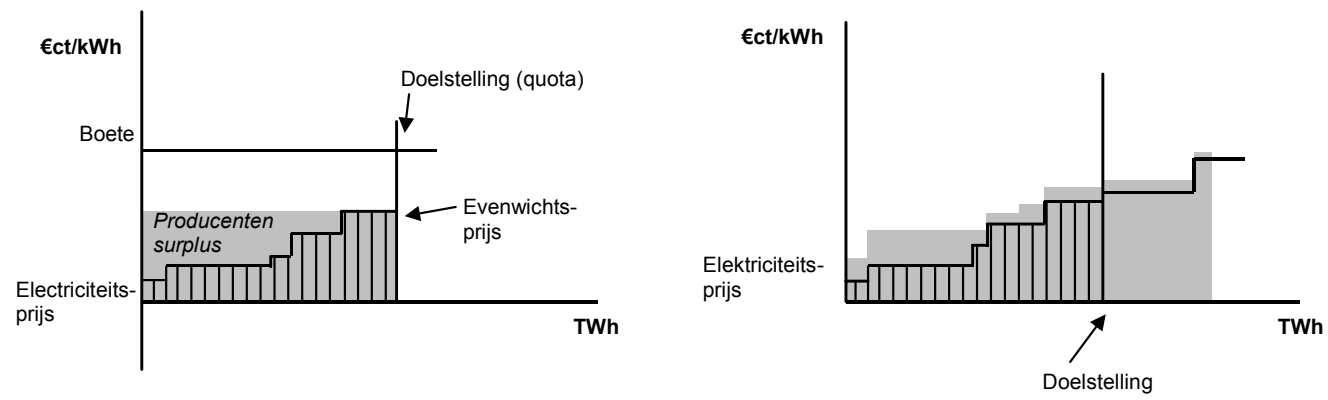

Figuur S.1 Voorbeeld van een aanbodcurve in een verplichtingssysteem (links) en een systeem van terugleververgoedingen (rechts). De grijze arcering geeft een indicatie van de totale uitgaven.

Uiteraard is het ontwerp van beide systemen in de loop van de jaren verfijnd om deze zwakheden op te vangen. Voor een verplichtingssysteem worden deze verfijningen hieronder besproken. Figuur 1 illustreert ook dat de werkelijke mate van overcompensatie sterk afhangt van de vorm van de aanbodcurve en van het ontwerp van het systeem. Het is daarom niet mogelijk om algemene uitspraken te doen over de kosten effectiviteit van een verplichtingssysteem in vergelijking met een systeem van terugleververgoedingen.

Er worden verschillende manieren toegepast om de kosten effectiviteit van een verplichtingssysteem te waarborgen. Ten eerste het geven van technologie specifieke (investerings-)subsidies, die een nivellerende werking hebben op de kostenverschillen tussen de technologieën. Een tweede mogelijkheid is het instellen van aparte quota voor (groepen van) technologieën of voor jaargangen. Daarnaast kunnen de opbrengsten van de betaalde boetes gebruikt worden voor het stimuleren van hernieuwbare energie, in plaats van voor algemene doeleinden, of het afkopen van de verplichting kan worden ontmoedigd door een relatief hoge boete. Tenslotte wijzen we op het systeem dat in verscheidene staten in de VS in gebruik is, waar de partijen met een verplichting (leveranciers) lange termijn contracten in competitie aanbieden aan producenten. De ervaringen in Europa en de Verenigde Staten leren dat zonder het gebruik van de hierboven genoemde mechanismen een verplichtingssysteem waarschijnlijk niet op kosten effectieve manier zal werken. 


\section{S.3.5. Steun van marktpartijen voor het verplichtingssysteem}

In het algemeen is er voldoende steun van marktpartijen voor het verplichtingssysteem, zowel in Europa als in de Verenigde Staten. Men beschouwt dit systeem vaak als minder gevoelig voor veranderende politieke omstandigheden dan subsidies. Eventuele kritiek richt zich daarom niet zozeer op het systeem zelf, als wel op specifieke onderdelen ervan. In eerste instantie hebben de verplichte actoren en industriële verbruikers zich vaak wel verzet tegen de invoering van een verplicht aandeel. Daarnaast is er in landen waar een systeem gebaseerd op teruglever vergoedingen functioneert, vaak een behoorlijke weerstand tegen het invoeren van een verplichting, omdat de sector gewend is aan het bestaande systeem.

\section{S.3.6 Eerlijke verdeling van kosten en baten over de belangengroepen}

Voor een lange (politieke) houdbaarheid van een verplichtingssysteem is een eerlijke verdeling van kosten en baten van duurzame energie over de belangrijkste stakeholders belangrijk. De ervaringen in verschillende landen wijzen erop dat verticaal geïntegreerde energiebedrijven in het voordeel zijn boven zelfstandige producenten omdat ze eigen productie kunnen inzetten voor het behalen van de verplichting, en dus minder risico hebben dan zelfstandige producenten. Dit impliceert dat TREC markten alleen kunnen functioneren binnen het kader van een goed werkende geliberaliseerde elektriciteitsmarkt. Daarnaast hebben eigenaren van grote installaties een schaalvoordeel met betrekking tot transactiekosten. Andere overwegingen kunnen zijn dat een verplichtingssysteem een zelfde steun biedt aan verschillende technologieën, hoewel dit vrij eenvoudig ondervangen kan worden, zoals hierboven beschreven. In sommige landen zijn bepaalde groepen verbruikers, zoals energie intensieve industrie in Zweden, uitgezonderd van een verplichting.

\section{S.4 Hoe ziet een goed ontworpen verplichtingssysteem eruit?}

Op basis van de ervaringen met een verplicht aandeel kunnen de volgende aanbevelingen voor het ontwerp van een verplichtingssysteem geformuleerd worden.

1. Liquiditeit van de markt. Het invoeren van een verplichtingssysteem zou alleen overwogen moeten worden als een voldoende liquide TREC markt gecreëerd kan worden, met dusdanig veel partijen dat geen van hen individueel invloed kan uitoefenen op de TREC prijs.

2. Lange termijn doelstellingen (quota). De quota moeten tenminste 10 jaar vooruit vastgesteld worden (liever nog 15 jaar of meer), zodat duurzame producenten een voldoende zekere basis hebben voor het afsluiten van lange termijn contracten voor TRECs. Het bieden van een lange termijn perspectief is misschien wel het meest belangrijkste element van een goed verplichtingssysteem, en is voorwaarde voor het aantrekken van substantiële hoeveelheden nieuwe investeringen in duurzame capaciteit.

3. Evenwichtige quota. Bij het vaststellen van quota is het belangrijk om rekening te houden met huidige en toekomstige aanbod en vraag. Dit betekent dat hoewel de quota duidelijk hoger moeten zijn dan de huidige productie, het wel mogelijk moet zijn om aan de verplichting te voldoen tegen redelijke kosten.

4. Gedifferentieerde steun. Ambitieuze doelstellingen of beperkte potentiëlen kunnen leiden tot hoge TREC prijzen, en zo de kosten effectiviteit van het systeem negatief beïnvloeden. Dit kan voorkomen worden door het introduceren van ofwel subgroepen van technologieën of jaargangen, ofwel door het verschaffen van subsidies aan de duurdere technologieën.

5. Verplichte actor. Als een verplichtingssysteem het belangrijkste beleidsinstrument is voor duurzame elektriciteit, is het aan te raden om de verplichting te leggen bij de leveranciers van elektriciteit, aangezien zij de verplichting in de praktijk toch zullen uitvoeren, en om zo onnodige administratiekosten te voorkomen.

6. Flexibiliteit. Vanwege het stochastische karakter van duurzame energie aanbod is het noodzakelijk om wat flexibiliteit in het systeem te brengen. De meeste gebruikelijke manier is het creëren van de mogelijkheid om (een gedeelte van) de verplichting af te kopen door het 
betalen van een boete. Daarnaast kan een verplichtingssysteem worden uitgebreid met regelingen betreffende banking en borrowing (resp. het vasthouden van certificaten en het gebruiken van nog aan te maken certificaten). Om strategisch gedrag te beperken is het aan te raden om deze opties te limiteren. Certificaten ten waarde van maximaal $25 \%$ van de verplichting zouden mogen worden vastgehouden. Borrowing zou niet langer dan drie maanden mogen duren, ofwel, een tekort zou na 3 maanden aangezuiverd moeten zijn.

7. Opbrengsten van betaalde boetes. De boetes, betaald door degenen die niet aan de verplichting voldaan hebben, zouden niet direct teruggesluisd moeten worden naar de certificatenmarkt, omdat dit de onzekerheden rond toekomstige TREC prijzen kan vergroten, en zo het afsluiten van lange termijn contracten voor TRECs kan bemoeilijken. Het gebruiken van de opbrengsten voor algemene doeleinden, daarentegen, tast de geloofwaardigheid van het systeem aan. Daarom is het aan te bevelen deze opbrengsten te gebruiken voor R\&D voor de duurdere hernieuwbare technologieën, of voor investerings- of productiesubsidies voor nieuwe hernieuwbare productiecapaciteit.

8. Internationale harmonisatie. Om de mogelijkheden voor internationale handel in TRECs in de toekomst te vergroten, verdient het aanbeveling om de keuze van duurzame bronnen die onder een verplichtingssysteem vallen af te stemmen op de Europese Richtlijn voor elektriciteit geproduceerd uit hernieuwbare bronnen (Directive 2001/77/EC).

9. Steun van de overheid. Essentieel voor een goed functionerend verplichtingssysteem is een sterke en lange termijn commitment van de overheid. Dit kan blijken uit goed gedefinieerde monitoring en verificatieregels en een adequate handhaving. Daarnaast is het stellen van lange termijn doelstellingen, zoals eerder genoemd, erg belangrijk.

\section{S.5 Is een verplichtingssysteem geschikt voor Nederland?}

In 2002-2003 zijn belangrijke wijzigingen doorgevoerd in het beleidsinstrumentarium voor hernieuwbare energie in Nederland. Er vond een verschuiving plaats van een systeem waarin vrijwillige vraag werd gestimuleerd door een ontheffing van de Regulerende Energiebelasting, naar de MEP regeling die directe vergoedingen biedt aan duurzame producenten. Het Ministerie van Economische Zaken is niet van plan om op korte termijn het beleidsinstrumentarium nogmaals ingrijpend te wijzigen, omdat dit schadelijk wordt geacht voor het vertrouwen van de markt.

Deze studie naar ervaringen met een verplichtingssysteem in het buitenland geeft een gemengd beeld. Hoewel een verplichtingssysteem in theorie effectief en kosten effectief is, kan op dit moment nog niet gesteld worden dat deze beloften helemaal worden waargemaakt. Enerzijds is dit te wijten aan de nog korte ervaring met het systeem, waardoor de effecten nog niet geheel duidelijk zijn, en men nog te kampen heeft met aanloopproblemen. Anderzijds kan geconcludeerd worden dat een verplichting een complex instrument is, wat alleen met een weloverwogen ontwerp goed kan functioneren.

Het lijkt de moeite waard om de ervaringen in het buitenland te blijven monitoren, om zo meer te kunnen leren over de effectiviteit en kosten effectiviteit van een verplichtingssysteem in de praktijk. Er zijn ook een aantal redenen waarom een verplichtingssysteem op termijn, na 2010, voor Nederland wel interessant zou kunnen zijn.

- De theoretische analyse geeft aan dat een verplichting een grotere kans geeft om gestelde kwantitatieve doelen te behalen, en dat de quota/boete combinatie een natuurlijke bovengrens vormt aan de totale kosten.

- De infrastructuur voor certificatenhandel is in Nederland al operationeel, dankzij de groencertificaten markt in het verleden en de huidige markt in Garanties van Oorsprong. De ervaring van de afgelopen jaren wijst uit dat de markt liquide genoeg zou zijn, en dat er voldoende marktpartijen actief zouden zijn. Echter, afhankelijk van het ontwerp van het systeem zouden de vier verticaal geïntegreerde energiebedrijven, net als in het Verenigd Koninkrijk, in het voordeel kunnen zijn boven zelfstandige producenten. 
- Internationale handel in TRECs is in principe interessant voor Nederland. Echter, waarschijnlijk zullen de meeste EU lidstaten er voor kiezen om voor de Europese indicatieve doelstellingen voor elektriciteit opgewekt met hernieuwbare bronnen voor 2010 nationale productie voorrang te geven boven handel. Dat betekent dat de relevantie van internationale handel in TRECs zal afhangen van de nationale en Europese ambities na 2010. Als er overeenstemming komt over doelstellingen voor bijvoorbeeld 2020, zou het voor Nederland waarschijnlijk goedkoper zijn om een gedeelte van de doelstelling in te vullen door TRECs te importeren uit landen die beschikken over een groter hernieuwbaar potentieel tegen relatief lage kosten. Hierbij moet wel opgemerkt worden dat internationale handel in Garanties van Oorsprong nu ook al mogelijk is en plaatsvindt; een verplichtingssysteem binnen $\mathrm{Ne}$ derland is geen voorwaarde, hoewel het niet onwaarschijnlijk is dat er reciprociteitseisen gesteld kunnen worden door exporterende landen. Het Zweeds/Noorse initiatief tot een gezamenlijke TREC markt, tenslotte, zou op termijn kunnen leiden tot een grotere en meer liquide markt.

\section{S.6 Tenslotte: systemen kunnen convergeren}

In de literatuur worden een verplichtingssysteem en een systeem van terugleververgoedingen vaak tegenover elkaar gesteld. De discussie over voor- en nadelen van beide systemen wordt dan nogal zwart-wit gevoerd. De praktijk laat zien dat aan het basismodel van beide instrumenten nog veel te verbeteren valt, en dat deze instrumenten daardoor meer op elkaar kunnen gaan lijken. Voorbeelden zijn:

- Het instellen van technologie-banden bij een verplichtingssysteem om zo de marktprijs (vergoeding) te differentiëren naar technologie en de kosten effectiviteit van het systeem te verhogen. Terugleververgoedingen worden ook gedifferentieerd per technologie.

- Het stimuleren van lange termijn contracten tussen producenten en leveranciers bij een verplichtingssysteem creëert een situatie die idealiter dezelfde lange termijn zekerheid biedt als een terugleververgoeding voor een vaste periode.

- De kosten effectiviteit van een systeem van terugleververgoedingen kan verhoogd worden door de tarieven over de tijd te laten dalen. In een verplichtingssysteem wordt de daling van technologiekosten gestimuleerd door de concurrentie in de markt.

- De koppeling van budgetten en tussendoelstellingen zoals nu bij de MEP voorzien is.

Een belangrijk verschil tussen de beide systemen blijft echter staan. Bij een verplichtingssysteem laat de overheid meer over aan de markt. De elektriciteitsleveranciers zijn de partijen die lange termijn contracten zouden moeten afsluiten, al dan niet door middel van een tender. Dit stelt eisen aan de kwaliteit van de liberalisering. Waarschijnlijk is de keuze voor een meer of minder marktgeoriënteerd systeem in grote mate cultureel bepaald.

Het doortrekken van deze trend kan leiden tot de mogelijkheid van een hybride systeem, waarin de MEP terugleververgoeding gecombineerd wordt met een verplichting. Hierin zouden verlaagde MEP premies kunnen fungeren als vaste subsidies in een systeem waar de energiebedrijven een verplichting hebben. Dit geeft prikkels aan de markt om efficiënter te werken, terwijl de lange termijn zekerheid van de MEP gedeeltelijk gehandhaafd blijft. Bovendien zou de verplichting een bovengrens opleggen aan de geproduceerde hoeveelheid hernieuwbare elektriciteit en zo voorkomen dat er een productie 'overschot' gesubsidieerd wordt ${ }^{35}$. De MEP zou tegelijkertijd de technologiespecifieke differentiatie leveren waardoor het aanbod in de TREC markt meer homogeen zou zijn in termen van kosten. Hiermee kan voldaan worden aan een van de voorwaarden voor een kosten effectief verplichtingssysteem.

35 In de MEP-wet wordt thans de invoering van een maximum subsidieplafond per jaar voorbereid dat hetzelfde effect beoogt. 